\title{
ANÁLISE E EVOLUÇÃO DA TARIFA SOCIAL DE ENERGIA ELÉTRICA NO BRASIL, 1985/2002
}

\author{
MAURICIO LOPES TAVARES
}

Dissertação apresentada à Escola Superior de Agricultura "Luiz de Queiroz", Universidade de São Paulo, para obtenção do título de Mestre em Ciências, Área de Concentração: Economia Aplicada.

\author{
PIRACICABA \\ Estado de São Paulo - Brasil \\ Dezembro de 2003
}




\title{
ANÁLISE E EVOLUÇÃO DA TARIFA SOCIAL DE ENERGIA ELÉTRICA NO BRASIL, 1985/2002.
}

\author{
MAURICIO Lopes TAVARES \\ Bacharel em Direito
}

Orientador: Prof. Dr. PEDRO VALENTIM MARQUES

Dissertação apresentada à Escola Superior de Agricultura "Luiz de Queiroz", Universidade de São Paulo, para obtenção do título de Mestre em Ciências, Área de Concentração: Economia Aplicada.

\author{
PIRA CICABA \\ Estado de São Paulo - Brasil \\ Dezembro de 2003
}


Dados Internacionais de Catalogação na Publicação (CIP) DIVISÃO DE BIBLIOTECA E DOCUMENTAÇÃO - ESALQ/USP

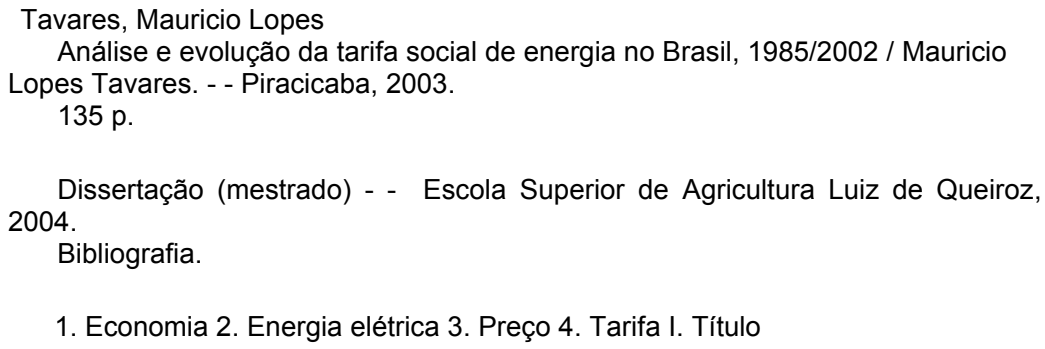

CDD 333.7932

\section{"Permitida a cópia total ou parcial deste documento, desde que citada a fonte - 0 autor"}


À minha esposa Daniele, abnegada incentivadora e companheira constante

Dedico esta obra. 


\section{AGRADECIMENTOS}

Ao Prof. Pedro Valentim Marques pelos ensinamentos, confiança e orientação a mim generosamente dedicados.

À Universidade de São Paulo, nas pessoas de todos seus Professores e Funcionários, em especial aos Professores Carlos José Caetano Bacha, Joaquim Bento de Souza Ferreira Filho, Alexandre Lahoz Mendonça de Barros, Ana Lúcia Kassouf, José Vicente Caixeta Filho, Ricardo Shirota e João Gomes Martines Filho que contribuíram decisivamente para minha formação e que tornaram possível esse trabalho.

Aos demais professores e funcionários do Departamento de Economia, Sociologia e Administração da ESALQ pela excelência em suas respectivas áreas de atuação, em especial à Maielli e Ligiana.

A todos os amigos conquistados ao longo do curso e que, com a convivência, enriqueceram minha formação como aluno e pessoa, em especial ao amigo Carlos $P$. Soares pelo inabalável e paciente apoio nos momentos mais difíceis.

A minha família por todo apoio, motivação e compreensão e em especial a meu Pai, por sua visão inspiradora e exemplo constante de integridade e determinação.

Aos meus amigos e colegas Octavio, Nestor, Pierre e José Edgard que generosamente compreenderam as dificuldades enfrentadas.

A todos, meu MUITO OBRIGADO. 


\section{SUMÁRIO}

Página

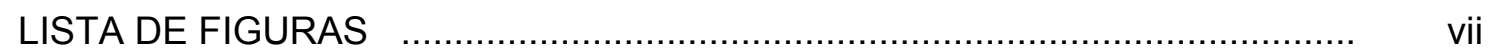

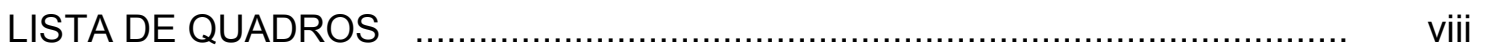

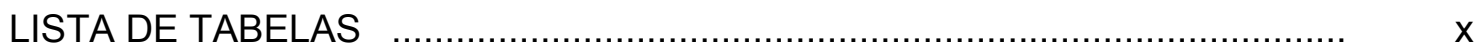

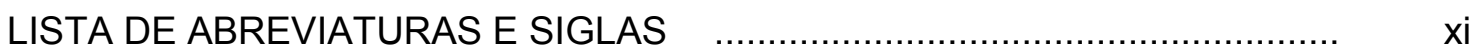

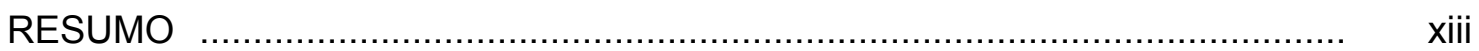

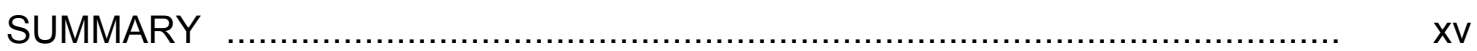

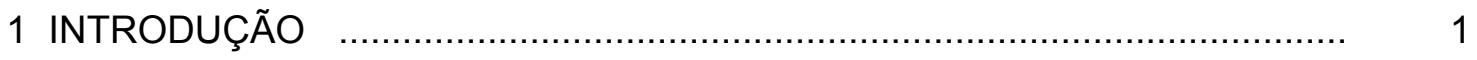

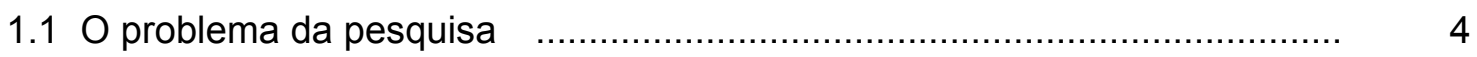

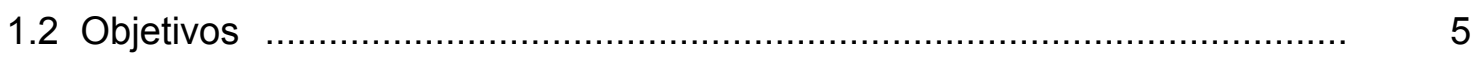

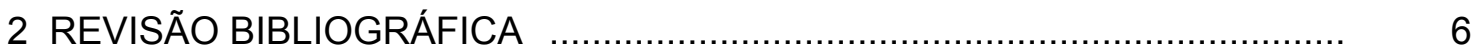

2.1 Características estruturais do setor elétrico brasileiro $\quad$.................................. 6

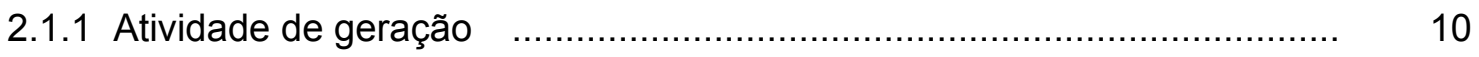

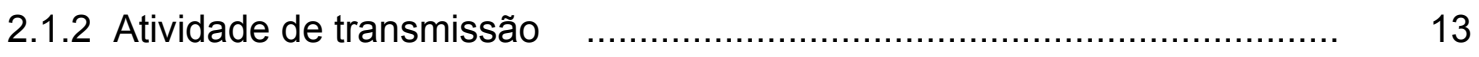

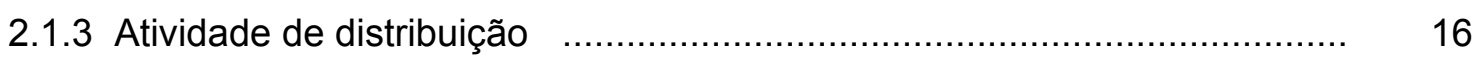

2.1.4 Atividade de comercialização $\quad$...................................................... 18

2.2 Monopólio e a Indústria de Serviços Elétricos Brasileira (ISEB) $\quad$........... 19

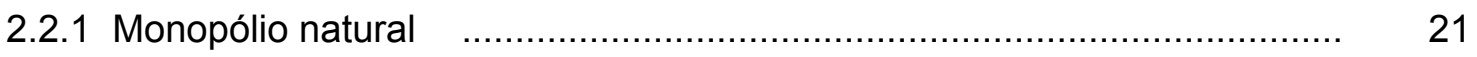

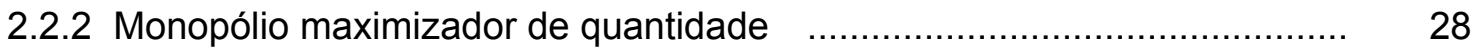

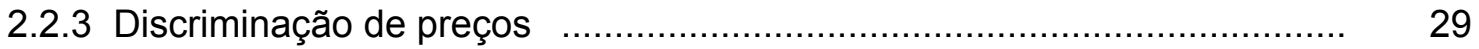

2.2.3.1 Discriminação de preços de $1^{\circ}$ grau $\quad$.................................................... 32

2.2.3.2 Discriminação de preços de $2^{\circ}$ grau $\quad$................................................... 34

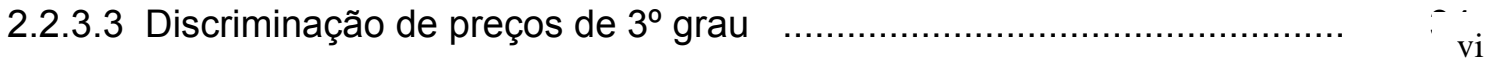

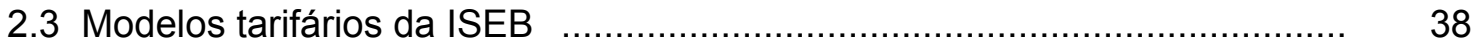

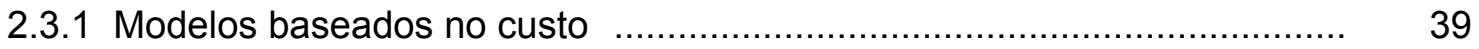


2.3.2 Modelo baseado no preço teto (price cap) ...................................... 44

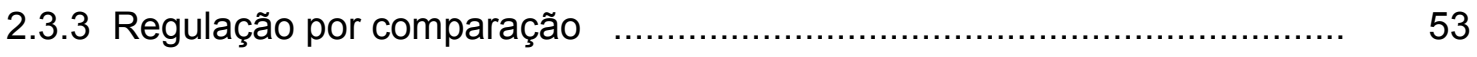

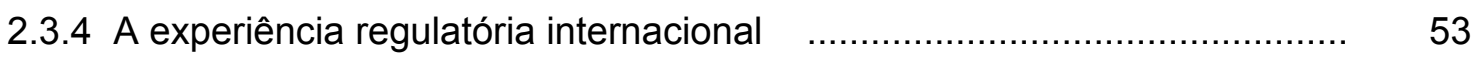

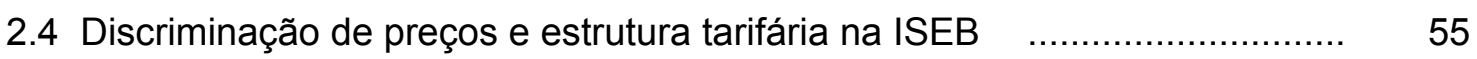

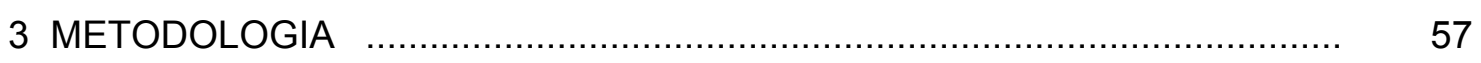

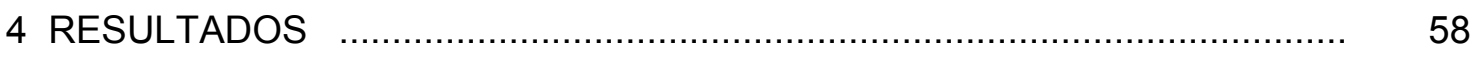

4.1 Evolução da Tarifa Social na ISEB ................................................ 58

4.1.1 Tarifa Social : período 1974-1985 ….............................................. 59

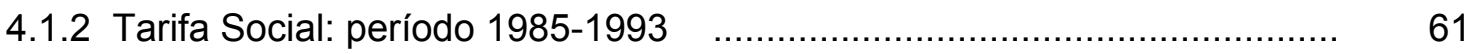

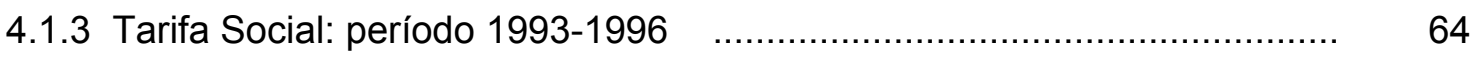

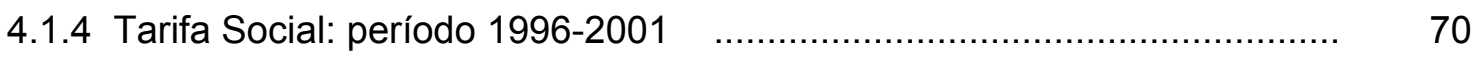

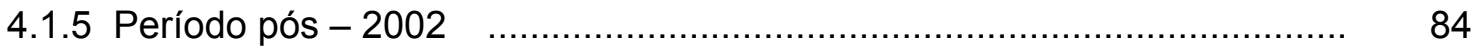

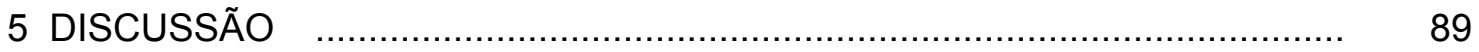

5.1 A experiência internacional: Tarifa Social na Ucrânia $\quad$............................. 109

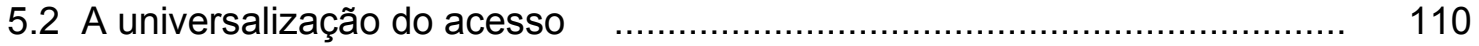

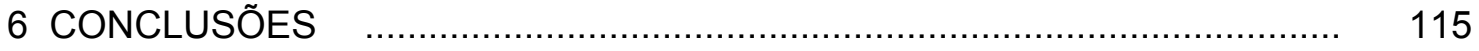

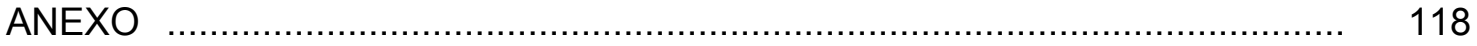

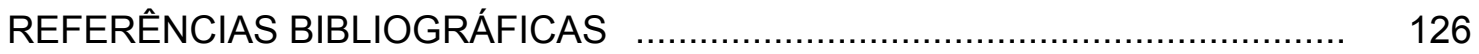




\section{LISTA DE FIGURAS}

Página

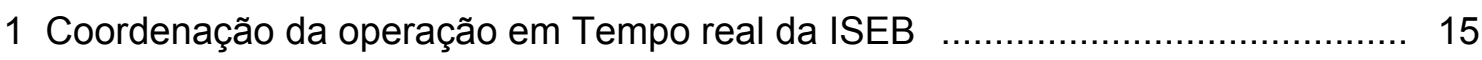

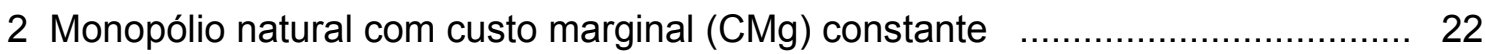

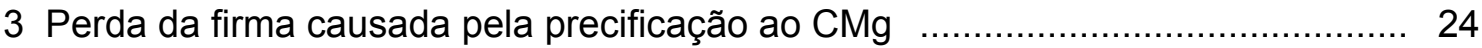

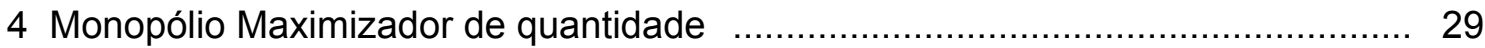

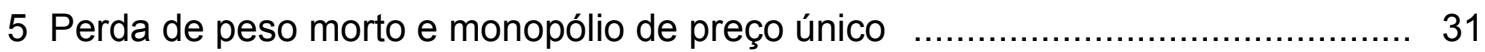

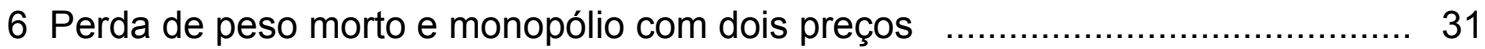

7 Diferenciação da demanda e preço em função da renda ................................... 34

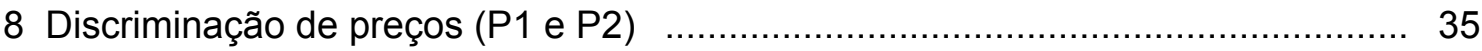

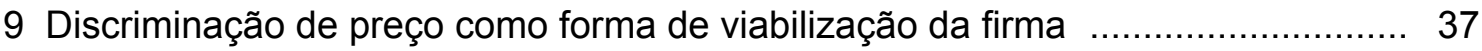

10 Composição da Conta de Energia ............................................................. 51

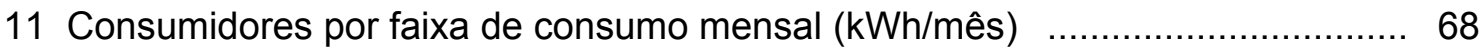

12 Distribuição de consumidores de baixa renda - faixas de consumo .................. 74

13 Consumo per capita de energia elétrica versus renda per capita $\quad$.................... 80

14 Aumento real da tarifa "residencial baixa renda" por nível de consumo mensal 84

15 Evolução da tarifa de energia elétrica média - setor residencial $\quad$.................... 106

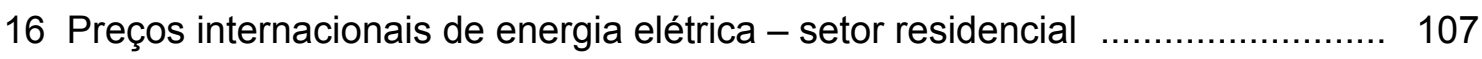

17 Preços da energia elétrica residencial em países em desenvolvimento ........... 107

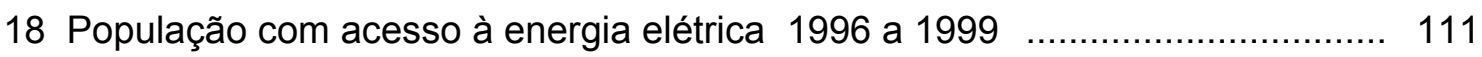

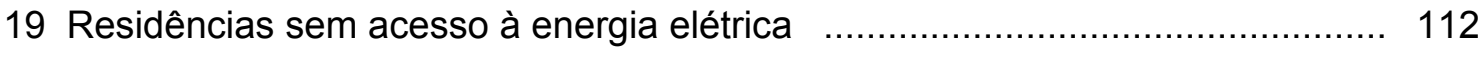




\section{LISTA DE QUADROS}

Página

1 Características de políticas regulatórias (taxa de retorno e price cap) $\ldots \ldots \ldots \ldots \ldots . . . . . .45$

2 Evolução Real das Tarifas Residenciais de Eletricidade ................................... 49

3 Composição do preço final da energia elétrica ............................................... 50

4 Tarifa Média por Setor de Consumo entre 1981 e 1992 .................................. 64

5 Reajustes das tarifas de energia elétrica em novembro de 1995 ........................66

6 Descontos da Subclasse Residencial Baixa Renda - (1995) …......................... 67

7 Efeitos da mudança dos critérios da tarifa social em $1995 \quad$............................... 68

8 Evolução das taxas de desconto por faixa de consumo - Tarifa Social .............. 69

9 Consumidores da subclasse residencial Baixa Renda (\%) ............................ 72

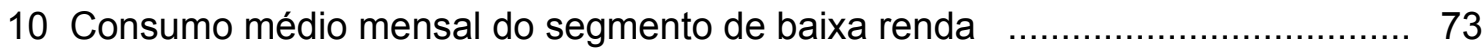

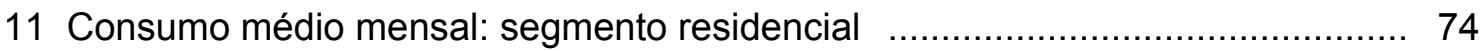

12 Posse de eletrodomésticos nas residências (Eletropaulo S.A.) …................... 75

13 Ausência de equipamentos x rendimento mensal - Estado de São Paulo 199877

14 Domicílios de baixa renda e domicílios com a Tarifa Social .............................. 81

15 Evolução das tarifas médias setoriais e inflação ......................................... 83

16 Faixas de desconto para a Tarifa Social 2003 ........................................... 85

17 Resumo da Simulação de Descontos de Baixa Renda .................................. 87

18 Evolução da regulamentação da Tarifa Social 1974-2003 ................................ 90

19 Gastos com energia elétrica - (\%) renda - 1987 e $1996 \quad$............................... 105

20 Percentual de cobertura de serviços públicos em 1993 e $2001 \quad$...................... 111

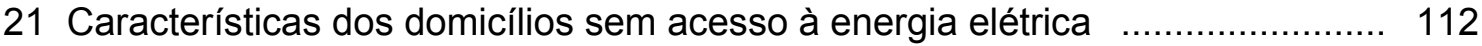

22 Parcela de excluídos elétricos por faixa de renda, participação das faixas de renda sobre o total da população e percentual de excluídos por faixa de renda sobre o total da população 
23 Tarifas diferenciadas em função do hábito de consumo (horários) ................. 120

24 Tarifas diferenciadas em função da quantidade e destinação do consumo $\quad$....... 121

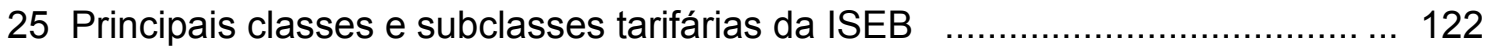




\section{LISTA DE TABELAS}

Página

1 Regressão linear: consumo domiciliar de energia elétrica versus renda $\quad \ldots \ldots \ldots \ldots . . . . . .78$

2 Regressão linear: consumo de energia elétrica per capita versus renda $\quad$.............. 79

3 Regressão linear: consumo em função de renda per capita, $n^{\circ}$ de moradores e $n^{\circ}$

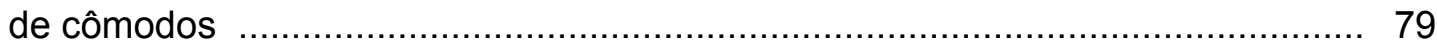

4 Regressão linear: consumo per capita como função de renda per capita e número de moradores e número de cômodos ............................................... 79 


\section{LISTA DE ABREVIATURAS E SIGLAS}

\begin{tabular}{ll} 
ABRADEE & Associação Brasileira de Distribuidoras de Energia Elétrica \\
ANEEL & Agência Nacional de Energia Elétrica \\
BNDE & Banco Nacional do Desenvolvimento Econômico \\
CANAMBRA & Comitê de Estudos Canadenses-Americano-Brasileiro \\
CBEE & Comercializadora Brasileira de Energia Emergencial \\
CCC & Conta de Consumo de Combustíveis Fósseis \\
CEAL & Companhia Energética de Alagoas \\
CEB & Companhia Energética de Brasília \\
CELESC & Centrais Elétricas de Santa Catarina S/A \\
CELG & Companhia Energética de Goiás \\
CEMIG & Companhia Energética de Minas Gerais \\
CENF & Companhia de Eletricidade Nova Friburgo \\
CEPISA & Companhia Energética do Piauí \\
CESP & Companhia Energética do Estado de São Paulo \\
CESP & Companhia Energética de São Paulo \\
CFLCL & Companhia Força e Luz Cataguases-Leopoldina \\
CHESF & Companhia Hidroelétrica do São Francisco \\
CPFL & Companhia Paulista de Força e Luz \\
CRC & Conta de Recursos a Compensar \\
CRMSE & Comitê de Revitalização do Modelo do Setor Elétrico \\
DENAEE & Departamento Nacional de Águas e Energia Elétrica \\
DNPM & Departamento Nacional da Produção Mineral \\
ELETROBRÁS & Centrais Elétricas Brasileiras S/A \\
ELETROPAULO & Eletropaulo Metropolitana Eletricidade de São Paulo \\
EME & Escala mínima eficiente \\
\hline
\end{tabular}




\begin{tabular}{ll} 
EXIMBANK & Export-Import Bank of the United States \\
FERC & Federal Energy Regulatory Commission \\
FFE & Fundo Federal de Eletrificação \\
GCE & Câmara de Gestão da Crise de Energia Elétrica \\
GCOI & Grupos Coordenadores para a Operação Interligada \\
GCPS & Grupo Coordenador do Planejamento do Setor Elétrico \\
ISEB & Indústria de Serviços Elétricos Brasileira \\
IUEE & Imposto Único sobre Energia Elétrica \\
MAE & Mercado Atacadista de Energia \\
MME & Ministério de Minas e Energia \\
MRE & Mecanismo de Realocação de Energia \\
ONS & Operador Nacional do Sistema \\
PNAD & Pesquisa Nacional por Amostragem de Domicílios \\
PND & Programa Nacional de Desestatização \\
PPT & Programa Prioritário de Termoelétricas \\
PPV & Pesquisa de Padrões de Vida \\
PRS & Plano de Recuperação do Setor de Energia Elétrica \\
REC & Regional Electricity Companies \\
RENCOR & Reserva Nacional de Compensação de Remuneração \\
REVISE & Revisão Institucional do Setor \\
RGG & Reserva Global de Garantia \\
RGR & Sistema Interligado Nacional \\
SAELPA & Redade Contas da União \\
TCU & Reral de Reversão \\
& Re Anônima de Eletrificação da Paraíba \\
\hline
\end{tabular}




\title{
ANÁLISE E EVOLUÇÃO DA TARIFA SOCIAL DE ENERGIA ELÉTRICA NO BRASIL, 1985/2002
}

\author{
Autor: MAURICIO LOPES TAVARES \\ Orientador: Prof. Dr. PEDRO VALENTIM MARQUES
}

\section{RESUMO}

Esse estudo teve como objetivo descrever de forma sistemática a evolução da política de preços da Tarifa Social de energia elétrica no período 1985/2002, de forma que fosse possível sua análise, superando as análises fragmentadas até então realizadas. A Tarifa Social consiste em um programa implementado pelo Ministério de Minas e Energia (MME), de barateamento do preço da energia elétrica para consumidores residenciais de energia elétrica, especialmente para famílias de baixa renda. A implementação da Tarifa Social foi caracterizada pela utilização dos mais diversos critérios para a concessão do benefício, foi influenciada por diferentes limites e condições regionais, sofreu alterações no montante do desconto concedido e na forma de cálculo do desconto. A diversidade de características na implementação dessa política tarifária dificultou a obtenção dos resultados pretendidos pelo Governo quando da sua implementação e a própria análise dessa iniciativa como uma política pública coerente ao longo do período considerado. A eficiência da política de Tarifa Social de energia elétrica apresenta-se de grande relevância pois pode implicar na inclusão ou exclusão de um grande número de famílias no mercado de consumo de energia elétrica. Atualmente o custo de concessão desses descontos concedidos à população de baixa renda superam $\mathrm{R} \$ 500$ milhões anuais em diminuição na receita das formas distribuidoras, custo esse que é compensado com tarifas mais elevadas 
aos consumidores de energia elétrica situados em outras classes. A descrição da evolução da Tarifa Social em função da evolução institucional da indústria de serviços elétricos brasileira (ISEB) permite superar a excessiva fragmentação de características que impedia a sua análise direta, dada a pressuposição de que sua evolução é dependente dos objetivos e parâmetros fixados para toda a indústria. Além da descrição da evolução da Tarifa Social realizou-se a análise da adequação dessa política aos pressupostos de eficiência econômica na fixação de preços descritos na literatura econômica. Para tanto essas políticas foram analisadas em função dos modelos descritos na teoria microeconômica, em especial aqueles da Teoria do Monopólio sob o enfoque do comportamento da firma monopolista de discriminação de preços. Também são descritas e analisadas outras políticas oficiais de ampliação do acesso da população de baixa renda ao serviço de energia elétrica, com enfoque na universalização do acesso físico da população às redes de distribuição de energia elétrica. 


\section{SOCIAL TARIFF OF ELECTRIC ENERGY IN BRAZIL, ANALYSIS AND EVOLUTION 1985/2002}

Author: MAURICIO LOPES TAVARES

Advisor: Prof. PEDRO VALENTIM MARQUES

\section{SUMMARY}

This study had the goal to describe systematically the evolution of the electricity's price policy, referred as Social Tariff, between 1985 and 2002, to make possible the analysis of this price policy overcoming the partial analysis that had been made up to this time. The Social Tariff consists in a program of the Mining and Energy Ministry to charge lower tariffs for residential consumers of electricity, especially for the families with low incomes. Since the Social Tariff was implemented, had been used many different conditions for the concession of this benefit, as different regional limits, different amounts of discount and different procedures to calculate this discount. That variety of conditions and characteristics of the Social Tariff made hard to achieve the goal of the Mining and Energy Ministry as to analyze the efficiency of this price policy in the referred period. The efficiency of this electricity's price policy for the low income families is relevant because it can implies in inclusion or exclusion from a large number of families in this market. Currently, the cost of these discounts for the electricity's consumption of low income families exceed $\mathrm{R} \$ 500$ millions/year, in form of lower revenues for the electricity's distribution firms. That revenue losses are compensate with higher tariffs imposed to the other consumers, classified in different tariff classes. 
The goal of this study was make possible analysis e describe the evolution of the Social Tariff, overcoming the major fragmentation of characteristics that avoid the direct analysis, comparing its evolution face to face with the evolution of institutional history of the electricity's industry, assumed that the definition of a tariff policy depends of the goals and characteristics fixed for the industry. This study also analyze this tariff policy as an efficient way to fix prices in terms of economic efficiency, as defined in the economic theory. These price policies where analyzed in terms of the microeconomics models, specially in terms of the Monopoly Theory and the behavior of the monopolistic firm that uses price discrimination. Other official policies implemented to improve the access of low income families to electricity's services where referred, specially the ones that intends to achieve the complete access of population to electricity's distribution network. 


\section{INTRODUÇÃO}

O objeto deste estudo está ligado aos critérios de determinação da tarifa (preço) de energia elétrica aplicado aos consumidores residenciais, considerado o objetivo declarado pelo Governo de ampliar o acesso da população de baixa renda a esse serviço público. Essa análise leva em conta a evolução histórica da indústria de serviços elétricos brasileira (ISEB) e suas características estruturais.

A análise das tarifas praticadas na ISEB considera a existência de um ente regulador que determina exogenamente seu valor tendo em vista o interesse público, não sendo permitido que as firmas, que operam em regime de monopólio, fixem livremente a tarifa.

Um dos critérios que podem ser utilizados pelo ente regulador, para a definição do valor da tarifa, privilegiando a eficiência alocativa, é a tarifação igualada ao custo marginal de prestação do serviço. Entretanto, com relação à Indústria do Setor Elétrico Brasileira-ISEB, bem como em quaisquer outras indústrias caracterizadas como monopólios naturais, a tarifação ao custo marginal se revelaria inadequada tendo em vista os elevados investimentos iniciais necessários para essa atividade. Essa característica dos monopólios naturais implica que o custo médio seja superior ao custo marginal de fornecimento dentro do intervalo relevante de produção, inviabilizando o alcance do equilíbrio econômico da firma que opera nesse regime de tarifação ao custo marginal.

Além dessa restrição quanto à eficiência, decorrente do fato que o preço não

pode ser igualado ao custo marginal, a experiência internacional e a literatura demonstram que a definição de tarifas em regimes de monopólio natural apresenta diversas dificuldades, sendo sido adotadas as mais diversas fórmulas e modelos. Uma característica comum a quase todos os modelos tarifários consiste na utilização de políticas tarifárias diferenciadas entre os consumidores, tais como níveis tarifários 
menores para setores considerados estratégicos ou para consumidores de baixa renda.

Nessas hipóteses, além de definir-se o modelo de cálculo das tarifas em geral, procede-se a adoção de critérios adicionais que diferenciam a tarifa "normal" para uma classe especial de consumidores dos quais é cobrada uma tarifa "especial", baseada em critérios decorrentes de uma política governamental de intervenção no domínio econômico, seja de cunho social ou desenvolvimentista.

Mesmo que não seja possível, ou desejável, a determinação da tarifa em um nível ótimo do ponto de vista da eficiência alocativa (preço igual ao custo marginal), a escolha final do modelo de cálculo de tarifas, bem como do "sub-modelo" de cálculo das tarifas especiais, não pode negligenciar uma solução eficiente em relação à adequada remuneração das firmas e dos demais objetivos do ente regulador.

Essas considerações são necessárias para o estudo das políticas tarifárias de cunho social praticadas na ISEB em diversas modalidades, especialmente aquelas voltadas para as famílias de baixa renda, que consiste no objeto principal do presente estudo. Nesse estudo será adotado o termo "Tarifa Social", que é a terminologia utilizada no pioneiro estudo do Ministério de Minas e Energia (MME) (Bitu, 1985), como generalização dos modelos tarifários adotados na ISEB visando privilegiar os consumidores residenciais de baixa renda com tarifas menores das praticadas para outros consumidores.

Em junho de 1985 o Ministério das Minas e Energia (MME) editou a Portaria $\mathrm{n}^{\circ} 817$, de 28 de junho de 1985, determinando que o Departamento Nacional de Águas e Energia Elétrica (DNAEE) apresentasse uma proposta de tarifas residenciais de cunho social, definindo o perfil consumidores de "baixa renda" a serem atingidos por essas tarifas.

O diagnóstico do MME (Bitu, 1985) foi que, apesar da tarifa residencial brasileira ser uma das mais baratas do mundo e ter sofrido desvalorização de $50 \%$ gradativamente no período de 1977 a outubro de 1985, ela ainda mostrava-se cara para a maioria da população quando comparada à renda média da população. $O$ resultado do estudo concluía pela necessidade da adoção de iniciativas, inclusive tarifárias, que garantissem à população de baixa renda o "consumo mínimo essencial" para: 
“- não inibir o uso mínimo dos eletrodomésticos essenciais para a família que já dispõe desses equipamentos;

- facilitar à família que ainda não dispõe dos eletrodomésticos essenciais, o acesso a seus usos mínimos." (Bitu, 1985, p.5)

Foi proposta uma tarifa residencial "transitória" e uma tarifa residencial "definitiva" para atender o objetivo de ampliação do acesso à energia elétrica às famílias de baixa renda. A implementação da nova política tarifária pelas empresas estatais foi adiada em decorrência da situação macroeconômica adversa decorrente da edição do Plano Cruzado (Bitu, 1985).

As opções de política tarifária apresentadas consistiam na implementação da Tarifa Social através de um preço maior às famílias mais ricas em favor da concessão de descontos às famílias mais pobres com base do nível de consumo mensal, impondo preços maiores a cada unidade de energia elétrica fornecida à medida que aumentasse o consumo, política essa decorrente da pressuposição de que riqueza e nível de consumo estariam diretamente correlacionados (França 1999). Essas alternativas de políticas tarifárias consistiam em ajustes da política vigente desde 1974, quando foi instituída a equalização de tarifas em nível nacional e eram concedidos descontos indiscriminados às famílias com menores consumos.

Além dessa iniciativa do MME de barateamento do consumo, algumas concessionárias de distribuição de energia elétrica já possuíam programas próprios de cunho social, como o de eletrificação de favelas, programas de atendimento a cortiços e de descontos e financiamentos na construção dos padrões de ligação à rede pública, conforme França (1999). Segundo Araújo (1997), iniciativas dessa natureza não se restringiam às empresas do setor elétrico, sendo praticadas por outras empresas de prestação de serviços públicos, como empresas de saneamento básico, telefonia e transportes, tanto no Brasil como em outros países em desenvolvimento.

Nos anos que se seguiram, a Tarifa Social passou por diferentes fases, com diferentes fundamentos, objetivos e resultados, os quais serão objeto de análise deste trabalho.

Essa análise considera, ainda, que a política tarifária de energia elétrica praticada para o seguimento residencial apresenta relevância crescente ao longo dos últimos anos no faturamento das concessionárias de distribuição de energia elétrica, 
além da evidente importância social do preço de acesso a um serviço público essencial, especialmente para a população de baixa renda.

\subsection{O problema da pesquisa}

Em diferentes épocas, por iniciativas das próprias concessionárias, do MME, do DNAEE ou da ANEEL mais recentemente, foram criados esquemas tarifários e não-tarifários que tinham como objetivo declarado pelo ente regulador propiciar a ampliação do acesso da população de baixa renda à energia elétrica.

Essas iniciativas adotaram formas diversas e heterogêneas ao longo do tempo quanto aos fundamentos técnico e teórico então utilizados. A fragmentação dessas iniciativas e a constante alteração dos critérios para a concessão dos descontos apresentou, ao longo do tempo, importantes reflexos sobre a porção da renda familiar consumida no pagamento da energia elétrica.

A análise dessas diferentes políticas tarifárias de concessão de descontos às famílias de baixa renda (Tarifa Social) irá considerar a mutação dos programas ao longo do período 1985-2002 descrevendo-os. Nessa análise também serão consideradas outras razões para implementação desses programas, em algumas oportunidades expressas e em outras omitidas, tais como o controle da inflação, o combate ao furto de energia, estímulo ao consumo de energia elétrica e de eletrodomésticos e ampliação do mercado e do faturamento das distribuidoras de energia elétrica. Um fator relevante nessa análise é que esses diferentes modelos tinham como restrição a auto-sustentabilidade financeira dada a necessidade de manter a estabilidade do faturamento das empresas concessionárias de distribuição de energia elétrica, conforme declarado expressamente em 1985 pelo Ministério das Minas e Energia (Bitu, 1985).

Esse trabalho buscará integrar a análise dessas diferentes políticas tarifárias, especialmente no período 1974-2002 à luz da Teoria do Monopólio, descrevendo as diferentes iniciativas em seus principais caracteres. Essa abordagem pretende contornar a escassez de dados que inviabilizam a análise empírica, pretendendo, entretanto, fornecer alguns subsídios para uma maior compreensão do tema que, até o momento, não foi objeto de estudos mais aprofundados. 


\subsection{Objetivos}

Pretende-se, inicialmente, descrever as características de operação e planejamento da ISEB de forma a verificar se o modelo de organização dessa indústria, em relação à estrutura do mercado, pode ser caracterizado como um monopólio natural, bem como a adequação da política tarifária, em especial a Tarifa Social, a essa estrutura de mercado.

O objetivo deste trabalho consiste em descrever a natureza das políticas referentes à Tarifa Social de energia elétrica implementadas no período 1985/2002, avaliando a sua adequação às características da ISEB, bem como à Teoria do Monopólio. 


\section{REVISÃO BIBLIOGRÁFICA}

\subsection{Características estruturais do setor elétrico brasileiro}

A caracterização da ISEB e sua evolução histórica é relevante no presente trabalho para a identificação das razões que justificam sua análise segundo a Teoria do Monopólio, iniciando-se por uma exposição da evolução institucional do setor.

Uma das características fundamentais do sistema brasileiro, que o diferencia de outros países, é que quase $90 \%$ da capacidade de geração instalada é de origem hidráulica e em termos de produção efetiva essa proporção chega, em média, a 95\% do total. A dependência da matriz energética nacional dessa forma de geração de energia deve se perpetuar nas próximas décadas apesar dos investimentos em outras formas de geração de energia como a nuclear (Angra I e II) e mais recentemente as usinas termelétricas do Programa Prioritário de Termoelétricas - PPT, projeto implementado após a crise de racionamento de 2001 e das formas de geração alternativas (eólica, biomassa e solar) previstas na Lei n 10.438/2002.

A capacidade de geração hidráulica instalada conta com grandes reservatórios de capacidade de regularização plurianual, implementados em diferentes bacias hidrográficas em diversas regiões do país (MME, 2003). Essas plantas de geração são interligadas aos centros de consumo por diversas redes de alta e extra-alta tensão, o que permite a coordenação da produção em diferentes partes do país, de acordo com o regime de chuvas peculiar de cada região. Essa característica única no mundo faz com que qualquer arranjo institucional que se pretenda implantar respeite essa especificidade.

Esse arranjo produtivo começou a ser implementado a partir da década de 1950, com a crescente intervenção estatal na ISEB que até então era formada por diversas empresas concessionárias de pequeno porte de atuação em âmbito 
municipal ou regional, em sua maioria de capital estrangeiro. O planejamento de geração, distribuição e transmissão através do governo federal tornou-se mais amplo quando o Presidente Jânio Quadros sancionou a lei de criação da Centrais Elétricas Brasileiras S/A (Eletrobrás) em 1961.

Até 1934, que marca o início da intervenção estatal na ISEB, a exploração de serviços relacionados ao fornecimento de energia elétrica elétrico era regido por acordos bilaterais de concessão (contratos), sendo concedentes as municipalidades. As concessionárias eram geralmente geradoras locais, cuja produção visava atender serviços tipicamente municipais, como iluminação pública e tração. Esses contratos de concessão se distinguiam pela cláusula contratual de garantia de retorno financeiro, que para as empresas nacionais consistia na garantia de uma remuneração mínima que variava de 5 a $10 \%$, enquanto para as empresas de capital estrangeiro vigorava a "cláusula-ouro", pela qual se garantia a equivalência entre as tarifas e a cotação do ouro. O Código de Águas de 1934 visava permitir uma maior participação do Estado no setor, tanto por investimentos diretos, como por um maior controle das concessionárias, por intermédio do Serviço de Águas Departamento Nacional da Produção Mineral (DNPM), que foi o primeiro órgão regulador do setor elétrico.

Essa primeira regulamentação da ISEB baseava-se em duas inovações: 1) atribuía à União a propriedade das fontes de energia hidráulica - o que transferia para a União o poder de outorgar concessões; 2) adotava o modelo tarifário do "custo de serviço" - remuneração com base no ativo imobilizado destinado à prestação do serviço - para determinação da remuneração da empresa, sendo as tarifas definidas em função desse parâmetro.

A necessidade de aumentos expressivos na capacidade de produção instalada para atender à crescente demanda, conjugada ainda à natural predominância da produção hidrelétrica que necessita de elevados investimentos iniciais e longo período até o retorno financeiro desse investimento, levou a uma progressiva transformação do setor que passou de predominantemente particular para quase que integralmente estatal. Para responder à necessidade de financiamento do setor, foi criado, em 1952, o Banco Nacional de Desenvolvimento Econômico (BNDE) como uma agência nacional voltada para o investimento no setor elétrico em contrapartida das verbas internacionais aportadas pelo Eximbank; além da criação do Fundo Federal de Eletrificação (FFE), com recursos do Imposto Único sobre Energia Elétrica. 
Com tais recursos a expansão do setor elétrico avançou para a consolidação do modelo de geração estatal (criação de Furnas Centrais Elétricas, em 1957), complementado pela organização de distribuidoras estaduais e de interligação dos sistemas das variadas bacias hídricas por meio de ampliação dos sistemas de transmissão. Esse período, de 1945 a 1962, se caracterizou pelo início do predomínio do investimento estatal sobre o capital privado.

A Eletrobrás, que foi constituída em 1962, tinha como objetivos básicos administrar a participação do governo federal no setor de eletricidade e promover a expansão da oferta de energia. As preocupações com o domínio do setor por empresas de capital estrangeiro num cenário de tarifas elevadas, ausência de investimentos na expansão da capacidade de geração e distribuição e o crescente consumo decorrente da industrialização levaram o governo a investir cada vez mais nesse setor (Abreu, 1999), financiada através de uma ampla recuperação de defasagens tarifárias anteriores. Entre 1964 e 1967 as tarifas foram reajustadas em média em $62,4 \%$ ao ano, enquanto a inflação cresceu em média $39 \%$ ao ano (Borestein \& Camargo, 1997).

Até 1963, os sistemas elétricos eram de pequeno porte, espalhados pelo país e construídos e operados por empresas privadas e por algumas empresas estatais que se consolidavam, como a Companhia Hidroelétrica do São Francisco (CHESF) e Furnas Centrais Elétricas, em âmbito federal, e a Companhia Energética de Minas Gerais (CEMIG) no plano estadual. As redes de transmissão então existentes eram bastante modestas, à exceção daquelas que alimentavam São Paulo e Rio de Janeiro (Santana \& Oliveira, 1999), além de não haver integração dos principais ramais.

$\mathrm{Na}$ primeira metade da década de 70 , em decorrência de planos regionais elaborados pelo Comitê de Estudos Canadenses-Americano-Brasileiro (CANAMBRA) para as regiões Centro-Oeste, Sudeste e Sul, iniciou-se a interligação dos sistemas regionais, marco inicial do Sistema Interligado Nacional (SIN), que ainda hoje é a base da operação da ISEB. Nesse período verificou-se um amadurecimento institucional das empresas do setor, além da compra pelo governo brasileiro das ações da Brascan Limited (Light), que levou que em janeiro de 1979 todas as concessionárias do setor de energia elétrica fossem constituídas totalmente por capital nacional. Da mesma forma, as decisões de investimento para a construção de novas hidroelétricas passou 
a ser feito de forma integrada, com enfoques supra-regionais (Borestein \& Camargo, 1997) de maximização do potencial de diferentes bacias hidrográficas.

$\mathrm{Na}$ segunda metade da década de 70 as empresas estatais foram utilizadas para a captação de financiamentos internacionais para a compra de equipamentos além das necessidades de expansão e operação do setor elétrico, como forma de captação de divisas, gerando o endividamento do setor em moeda estrangeira e um excesso de capacidade instalada. A partir de 1982 o setor sistematizou-se sob intensa coordenação da Eletrobrás e através do Grupo Coordenador do Planejamento do Setor Elétrico (GCPS), com planejamento integrado entre as empresas federais e estaduais. No plano técnico consolidaram-se as metodologias de base probabilística (que determinava a necessidade de expansão da capacidade de geração com base na probabilidade de não-suprimento de energia) em detrimento da metodologia determinística de garantia de "energia firme" suficiente para atendimento da demanda (Borestein \& Camargo, 1997).

Essa estrutura da ISEB só veio a ser alterada na segunda metade da década de 90, com o processo de privatização e com a substituição da Eletrobrás pelo Operador Nacional do Sistema (ONS) e pelo Mercado Atacadista de Energia Elétrica (MAE) na função de coordenação da operação do sistema e na substituição do $\mathrm{MME}$ pela Agência Nacional de Energia Elétrica (ANEEL) na função de regulação das relações entre os diversos agentes e consumidores.

Nesse novo modelo as atividades de geração, transmissão, distribuição e comercialização de energia elétrica deveriam ser fortemente segmentados, sendo vedado que as empresas da ISEB possuíssem ativos vinculados a mais de uma dessas atividades. Isso implicou, inclusive, que diversas empresas de atuação verticalizada em todos esses setores fossem cindidas, quando do processo de privatização, em empresas que atuassem em apenas uma dessas atividades.

A razão dessa segmentação da atuação das firmas que compõem a ISEB era permitir introduzir mecanismos de mercado, especialmente concorrência entre os agentes em todas as atividades em que isso fosse possível. A atividade de geração de energia foi considerada um setor que poderia funcionar sob o regime de concorrência, a transmissão deveria permanecer como uma atividade "neutra" sob controle estatal e a distribuição de energia deveria funcionar sob o regime de monopólio em sua área de concessão, no que se denominou de "mercado cativo", à exceção de grandes 
consumidores que receberam autorização para adquirir energia de qualquer empresa distribuidora. A atividade de comercialização consiste na autorização para que determinadas empresas atue na atividade de arbitragem do comércio de energia, exercendo a contratação da geração e revenda aos consumidores, sendo exercido de maneira competitiva, por conta e risco dos empreendedores, mediante autorização da ANEEL.

Tendo em vista o objetivo desse estudo de analisar a Tarifa Social e a ISEB no contexto da Teoria do Monopólio faz-se necessário descrever cada uma dessas atividades quanto à estrutura de mercado no contexto da ISEB.

\subsubsection{Atividade de geração}

A participação da energia hidráulica na matriz energética nacional é da ordem de $42 \%$ e a geração hidrelétrica tem garantido, nos últimos anos, a produção de cerca de $95 \%$ da eletricidade consumida no país. A capacidade instalada atualmente é da ordem de $61 \mathrm{GW}$, o que representa cerca de $37 \%$ do potencial de geração já inventariado e $23 \%$ do potencial de geração estimado (ANEEL, 2002). Devido à importância da energia de origem hidráulica na ISEB, no presente estudo as referências à atividade de geração de energia considerarão somente essa fonte.

Apesar da tendência de aumento da participação de outras fontes de geração de energia elétrica (principalmente termoelétrica) tudo indica que a energia hidráulica continuará sendo, nos próximos anos, a principal fonte geradora de energia elétrica do Brasil. Embora os maiores potenciais hidráulicos remanescentes estejam localizados em regiões distantes dos principais centros consumidores, a ANEEL estima que nos próximos anos pelo menos $50 \%$ da necessidade de expansão da capacidade de geração seja de atendida pela geração hidráulica. A crescente participação de outras formas de geração decorre não só do estímulo governamental para diversificação da capacidade de geração, mas também da crescente resistência social à construção de grandes reservatórios, seja pelos impactos sociais (remoção de população local e inundação de terras agriculturáveis), seja pelos impactos ecológicos que essas obras acarretam. Estima-se que a área inundada por aproveitamentos hidrelétricos no Brasil seja, atualmente, equivalente a $82 \%$ da extensão territorial do Estado do Rio de Janeiro e $0,4 \%$ de todo o território brasileiro. 
Segundo a ANEEL, o potencial hidrelétrico brasileiro é estimado em cerca de $260 \mathrm{GW}$, dos quais 40,5\% estão localizados na Bacia Hidrográfica do Amazonas. Entre as demais bacias, destacam-se a do Paraná, com 23\% desse potencial, a do Tocantins $(10,6 \%)$ e a do São Francisco (10\%). As bacias do Uruguai e do Atlântico Leste representam cerca de $5 \%$ cada uma e as demais (Atlântico Sudeste e Atlântico Norte/Nordeste) somam juntas apenas $5 \%$ do referido potencial. Contudo, apenas $63 \%$ desse potencial foi inventariado, de modo que essas proporções mudam significativamente em termos de potencial conhecido. A Bacia do Amazonas possui apenas $19,4 \%$ do seu potencial de geração inventariado (ANEEL, 2002).

A geração hidrelétrica no Brasil é constituída essencialmente de grandes empreendimentos. Num universo de 433 centrais hidrelétricas registradas junto à ANEEL, destacam-se as 23 centrais hidrelétricas com capacidade de geração superior a $1.000 \mathrm{MW}$ correspondem a $71,4 \%$ da capacidade instalada no país. Os 337 empreendimentos com potência igual ou inferior a $30 \mathrm{MW}$ representam apenas 2,4\% da capacidade instalada (ANEEL, 2002). Ilustrativamente, tem-se que somente a Hidrelétrica de Itaipu é responsável atualmente por cerca de $25 \%$ de toda energia elétrica consumida no Brasil, sendo que sua tarifa é vinculada à taxa de câmbio do dólar norte-americano, em decorrência da propriedade binacional Brasil-Paraguai dessa usina.

O setor de geração foi considerado como adequado para a promoção de um ambiente concorrencial no novo modelo da ISEB, implementado no contexto de privatização da segunda metade da década de 1990. Nesse contexto foram implementados o MAE e determinada a diminuição da energia contratada de longo prazo entre as empresas distribuidoras e geradoras, de forma que a negociação ocorresse no mercado "spot".

Considerando-se que essencialmente a capacidade de geração de energia elétrica na ISEB é de natureza hidráulica deve-se destacar cinco características dessa forma de geração de energia que são relevantes no âmbito do presente estudo, especialmente quanto a sazonalidade da produção, a necessidade de grandes investimentos para construção das plantas e a necessidade de coordenação dos agentes produtores.

Teoricamente, uma usina hidrelétrica poderia operar continuamente 365 dias por ano; isto é, com um fator de capacidade de $100 \%$ ou em valores próximos a esse. 
Essa capacidade é verificada em usinas de geração que utilizam outras tecnologias como a nuclear ou termoelétrica, sendo necessárias interrupções na produção apenas para manutenção de equipamentos. Para as usinas hidroelétricas esse índice é da ordem de apenas 40\%, em função da necessidade de manutenção e das características de vazão da bacia hidrográfica em que se situa.

Essa influência das características da bacia hidrológica implica na necessidade de adequação da vazão para outros fins como a manutenção de certo nível adequado do reservatório para a captação de água para abastecimento, navegação ou irrigação. A grande extensão territorial e as variações climáticas e hidrológicas do país, tende a gerar excedentes de produção hidrelétrica em determinadas regiões e períodos do ano. Apesar do dimensionamento dos reservatórios para incluir a variação sazonal pluviométrica essa capacidade é limitada e influenciada por longos períodos de estiagem, circunstância que pode levar a usina a interromper a produção de energia.

A partir da promulgação da Lei n. ${ }^{\circ} 9.433 / 97$ os recursos hídricos deixaram expressamente de ser controlados pelo setor elétrico e passam a serem controlados pelo Sistema Nacional de Gerenciamento de Recursos Hídricos, sendo priorizado o uso múltiplo das águas e não da produção de eletricidade.

Ao contrário de outras tecnologias de geração de energia, especialmente a termoelétrica, a construção de novas plantas de geração hidráulica envolve grandes investimentos iniciais e um período de aproximadamente 10 a 15 anos para que a usina entre em operação, ao contrário dos 3 anos necessários para uma termoelétrica. Essa característica faz com que a expansão da capacidade de geração com base hidráulica, e da mesma forma as usinas nucleares, envolva projeções sobre o aumento da demanda em horizontes muito maiores do que as usinas termoelétricas, com maior incerteza.

Essa desvantagem da tecnologia hidráulica (e nuclear) quanto ao alto investimento inicial e do elevado custo médio é compensada pelo baixo custo marginal de geração, que permite o fornecimento de energia por preços muito inferiores às usinas termoelétricas, especialmente pelo elevado custo dos insumos (carvão, óleo ou gás) que inexiste nas usinas hidrelétricas e nucleares.

A maioria das usinas hidrelétricas na ISEB foram construídas sob a lógica da gestão integrada e de longo prazo do estoque de água. Em sua maioria foram 
construídas por empresas estatais federais de atuação multi-regional e permanecem estatais até o presente momento, não tendo sido incluídas no processo de privatização da segunda metade da década de 1990, à exceção de algumas geradoras estaduais de dimensão relevante, especialmente no Estado de São Paulo, com a Companhia Energética do Estado de São Paulo (CESP), que foram privatizadas.

Nesse sistema, as usinas estão interligadas, não só pelo sistema de transmissão, mas também hidraulicamente, uma vez que se situam em seqüência nos diversos rios onde estão localizadas. A água liberada por um reservatório afeta o reservatório de todas as usinas a jusante e pode ser armazenado, vertido (liberação de água do reservatório sem geração de energia) ou utilizado na geração de energia.

A possibilidade de regularização da quantidade ótima de água a ser utilizada para a produção de energia elétrica em todas usinas de uma mesma bacia hidrogáfica, aliada à interligação elétrica das usinas, possibilita um gerenciamento eficiente dos recursos hídricos (Abreu, 1999). Essa estrutura permite a exploração dos potenciais de forma integrada, proporcionando uma capacidade de produção de energia elétrica superior à simples agregação das capacidades individuais. Esse aumento de eficiência é obtido pela programação conjunta da produção de energia das usinas do sistema, evitando-se o vertimento de água de cada usina em separado, preservando o armazenamento e as alturas de quedas d'água do sistema como um todo.

\subsubsection{Atividade de transmissão}

A grande dependência da ISEB da energia hidráulica, com os melhores potenciais hidrelétricos do país localizados distante dos grandes centros consumidores, implicou no desenvolvimento de um complexo de transmissão de grandes quantidades de energia elétrica e, posteriormente, a interligação do sistema visando garantir flexibilidade e confiabilidade do fornecimento.

Além da finalidade de distribuição espacial da energia gerada, conectando as usinas geradoras às subestações de distribuição, o setor de transmissão foi arquitetado visando à otimização temporal e econômica da geração, isto é, a alocação eficiente e racional da geração de energia através da operação interligada. Essa 
característica permite que um déficit na geração de energia em uma determinada região possa ser compensada pelo excesso de capacidade de geração em outra.

A existência da interligação do sistema de transmissão de energia elétrica entre diversas regiões do país permite que, sob a regência do ONS, seja otimizada a geração de energia elétrica, que prioritariamente será gerada nas plantas com menor custo marginal e que apresentem condições hidrológicas favoráveis (reservatórios cheios), independentemente de sua localização física.

Desequilíbrios locais entre consumo e produção são automaticamente compensados pelas regiões próximas que serão solicitadas a consumir ou a produzir de acordo com o desequilíbrio apresentado. Entretanto, caso o desequilíbrio supere a capacidade técnica das instalações de regiões próximas ou problemas técnicos interrompam a transmissão em redes de relevância, a sobrecarga rapidamente se propaga por todo o sistema, interrompendo seu funcionamento.

A operação do SIN, atualmente a cargo do ONS, consiste na apuração instantânea da quantidade de energia demandada pelos consumidores. Em função dessa demanda o ONS, na hipótese atual, determina que determinadas plantas das mais diversas firmas, estejam nas Regiões Sul, Sudeste ou Nordeste, entrem em operação, de acordo com o equilíbrio de carga do sistema. Num primeiro momento é determinada a produção nas plantas hidráulicas de menor custo. À medida que a demanda de energia aumenta, sucessivamente é determinado o início da produção de plantas com custos de geração superiores, até que a demanda seja completamente atendida.

A organização institucional implementada na segunda metade da década de 1990 manteve essa atividade sob controle do Estado, sem a alienação do controle sobre a infra-estrutura existente via privatização, sendo permitida a participação da iniciativa privada na construção de novas linhas segundo licitações promovidas pela ANEEL. Mesmo com a autorização da participação da iniciativa privada tal atividade deve permanecer sob a estrutura de monopólio coordenado pelo ONS, sendo vedada a concorrência entre as firmas que atuam nessa atividade. A concorrência nesse setor certamente seria inviável do ponto de vista técnico sob pena de congestionamento das redes de transmissão que ofertassem o serviço à menor tarifa, levando ao colapso do sistema. 
Constitui obrigação do ONS, em substituição ao GCPS da Eletrobrás, garantir o tratamento isonômico e neutro no estabelecimento dos parâmetros e na formulação dos despachos e coordenação e controle da operação das atividades de geração e transmissão de energia elétrica no SIN. Para esse fim seu Conselho de Administração é composto por representantes da atividades de Geração (7 membros), Transmissão (4 membros), Distribuição (7 membros) e do Poder Concedente, indicado pelo MME (1 membro).

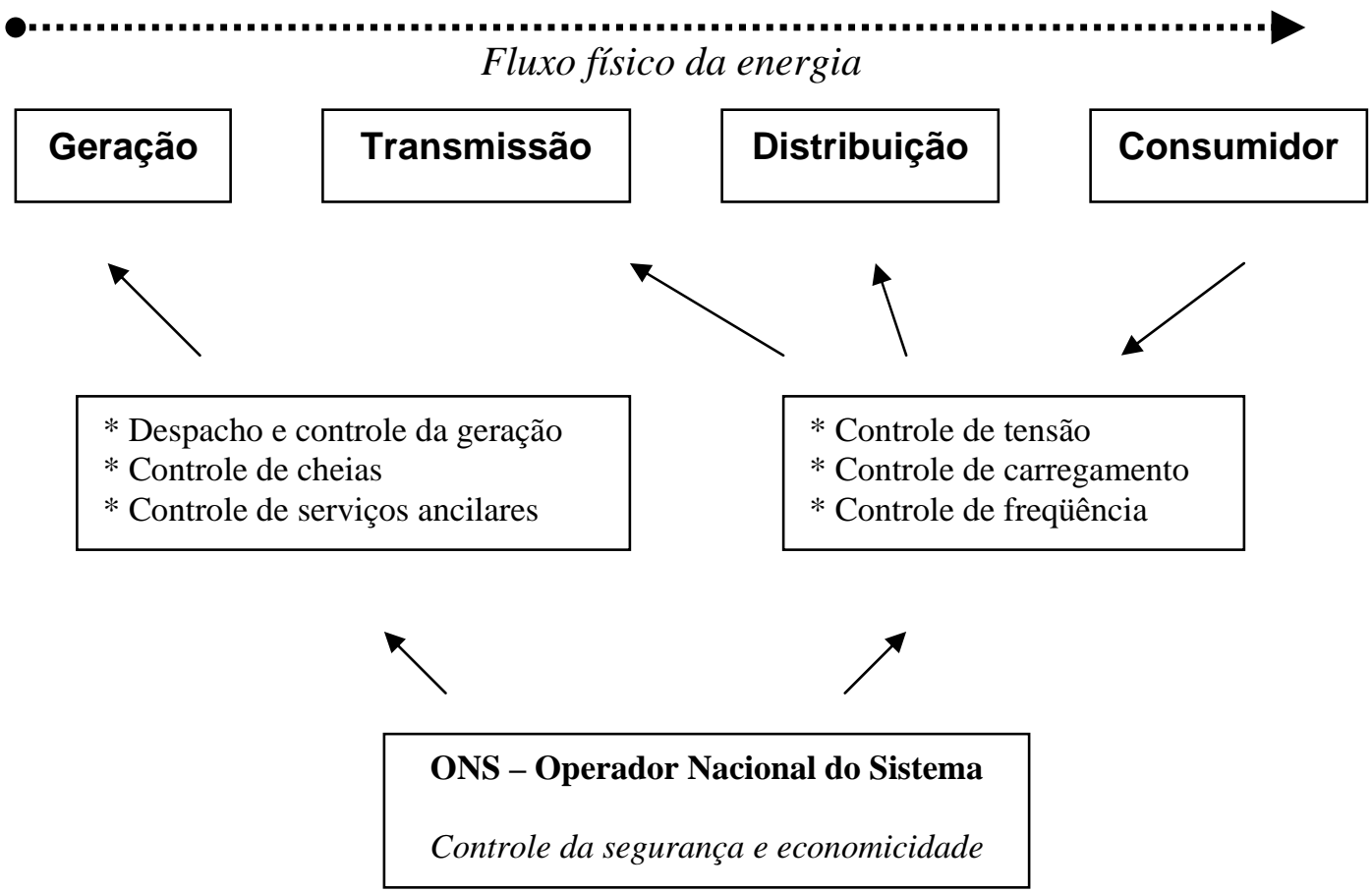

Figura 1 - Coordenação da operação em Tempo real da ISEB.

Fonte: adaptado de Abreu (1999)

Suas principais atribuições são a realização do "despacho centralizado", ou seja a ordem para entrada em operação de cada usina geradora ligada ao SIN, com base nos custos de geração e a implementação do Mecanismo de Realocação de Energia - MRE, com as conseqüentes contabilizações do fluxo físico de energia que permitirão o cálculo da remuneração de cada usina ou empresa geradora interligada.

O despacho com base em custos visa assegurar a operação ótima do sistema e, ao mesmo tempo, evitar a formação e exercício de poder de mercado entre as empresas geradoras na fixação da quantidade e preço da energia ofertada. Essa forma de administração dos potenciais hídricos envolve o cálculo centralizado dos 
custos de oportunidade associados à água armazenada nos reservatórios, através de um modelo matemático previamente definido e de conhecimento de todos os agentes da ISEB. Desta forma, as empresas de geração hidroelétrica não podem definir os preços e a quantidade da energia gerada ou ofertada.

O Mecanismo de Realocação de Energia (MRE) é outro ponto central do modelo comercial da ISEB. Tal mecanismo consiste em um arranjo de mitigação de riscos financeiros que venham a ser impostos às firmas possuidoras de plantas de geração hidroelétrica devido à variabilidade das vazões, que implica na quantidade de energia a ser gerada, despachada e remunerada, através do compartilhamento destes riscos pelo conjunto de geradores.

Em seu nível mais elementar, o MRE assegura a cada usina hidroelétrica um valor fixo denominado "Energia Assegurada" correspondente à capacidade de geração ideal e em cada evento de contabilização utilizada na repartição da produção e faturamento total do conjunto de usinas hidroelétricas interligadas ao SIN.

O sistema de "despacho" centralizado operado tecnicamente pelo ONS tem relevância para o presente estudo ao determinar que o produto de cada firma integrada ao SIN, em especial as usinas hidroelétricas e as empresas de transmissão, não é determinado pela firma, mas sim segundo um algoritmo baseado em dados históricos de capacidade de geração em função do custo de oportunidade de utilizar determinado reservatório ou não, confrontados com informações atualizadas a cada momento das capacidades hídricas verificadas em cada bacia hidrológica.

\subsubsection{Atividade de distribuição}

O mercado de distribuição de energia elétrica é atendido por 64 concessionárias de serviços públicos, estatais ou privadas, que abrangem todo o País. As concessionárias estatais estão sob controle dos governos federal, estaduais ou municipais. Em várias concessionárias privadas verifica-se a presença, em seus grupos de controle, de diversas empresas nacionais, norte-americanas, espanholas e portuguesas. São atendidos cerca de 47 milhões de unidades consumidoras, das quais $85 \%$ são consumidores residenciais, em mais de 99\% dos municípios brasileiros. O consumo residencial representa cerca de $27 \%$ do consumo total, 
enquanto que sua participação na receita dos concessionários é de aproximadamente 40\% (MME, 2003).

A atividade de distribuição de energia elétrica compreende o atendimento final da demanda, consistindo na captação da energia das redes de transmissão, sua transformação em subestações para tensões adequadas ao consumo final e o transporte local até os consumidores através de redes localizadas especialmente em vias públicas. É nesse elo da cadeia de fornecimento de energia em que ocorre o relacionamento direto com o consumidor, a tributação e cobrança de todos encargos estabelecidos em favor de outros agentes do setor. Suas obrigações incluem a manutenção de todos os equipamentos necessários à atividade, o atendimento aos pedidos de novas ligações e o combate ao furto de energia.

Tradicionalmente a atividade de distribuição é exercida em regime de monopólio sobre todas as unidades consumidoras localizadas na área de concessão de cada firma, sejam consumidores de energia industriais, comerciais, residenciais ou do setor público, o que é conhecido como "mercado cativo". A vedação à concorrência nessa atividade decorre da necessidade de duplicação das redes para que uma empresa concorrente atue no mesmo mercado, o que torna irracional essa solução.

A atuação dessas empresas em regime de monopólio sobre as áreas concedidas é limitada no tempo, em prazos que variam em torno de 20 a 30 anos para a exploração da atividade, findo o qual todos os ativos reverterão ao Estado que poderá assumir o serviço ou concedê-lo a outra empresa.

A tarifa que pode ser cobrada dos consumidores "cativos", ou seja, de todos aqueles que estejam localizados na área de concessão da empresa que não preencham os requisitos legais para tratamento como "consumidores livres", são fortemente reguladas pelo ente regulador, segundo regras definidas previamente no contrato de concessão e na legislação específica. No regime atual tal controle é exercido pela ANEEL que procede anualmente ao reajuste das tarifas pelos índices de inflação verificados no período e a cada 5 anos, em média, efetua o processo de revisão tarifária, onde é reavaliada em profundidade a adequação das tarifas autorizadas. Como será detalhado adiante, esse regime tarifário é denominado "pricecap" e define as tarifas máximas que podem ser praticadas. 
A concorrência na atividade de distribuição ocorre somente em relação aos "consumidores livres" que são autorizados a contratar o fornecimento da concessionária de distribuição local ou de qualquer outra. Os consumidores que são incluídos nessa categoria dependem de critérios fixados na legislação, essencialmente a característica de serem usuários de grandes quantidades de energia.

Quando é contratado o fornecimento de uma distribuidora diferente daquela que detém a concessão local, não são construídas quaisquer redes físicas. Essa negociação é liquidada essencialmente em termos contábeis, pois a energia não é fornecida fisicamente pela concessionária contratada, mas sim pela concessionária local. Apurado o consumo, a concessionária local é remunerada pela utilização de sua rede (por uma tarifa denominada "valor normativo", que idealmente remunera os custos de manutenção, medição e faturamento) e a concessionária contratada recebe a tarifa pela energia efetivamente utilizada. Esse sistema é semelhante ao implementado no setor de telecomunicações e que permite ao consumidor a escolha da prestadora do serviço interurbano e internacional de ligações, independentemente da concessionária que atende à região, monopolista em relação às ligações locais.

Esse mecanismo de inserção de competição no setor tem apresentado resultados significativos, sendo que as tarifas cobradas do "consumidor livre" tem sido sensivelmente inferiores às praticadas com as demais classes de consumidores. A ANEEL vem progressivamente incluindo consumidores nessa categoria, ao diminuir as exigências quanto ao consumo mensal para que sejam beneficiados por esse mecanismo.

\subsubsection{Atividade de comercialização}

A atividade de comercialização de energia elétrica compreende a compra, a importação, a exportação e a venda de energia elétrica no âmbito do Mercado Atacadista de Energia- MAE a outros comercializadores, ou a consumidores que tenham livre opção de escolha do fornecedor por empresas autorizadas pela ANEEL que não detenham ativos de geração, transmissão e distribuição.

Por se tratar de atividade de arbitragem e de negociação financeira no âmbito do MAE essa atividade não possui maior relevância para o presente estudo. 


\subsection{Monopólio e a Indústria de Serviços Elétricos Brasileiro (ISEB)}

A ISEB é uma indústria onde a atuação das firmas é fortemente regulada pelo Estado, especialmente pela ANEEL. A forte intervenção estatal regulando o comportamento das firmas nessa indústria impõe restrições ao comportamento das firmas tais como condições de produção, de comercialização e preços (tarifas). A regulação estatal é aplicada pois a maioria dos consumidores de energia encontra-se em situação de enfrentar uma empresa de distribuição de energia que atua de forma monopolística sobre a sua região. Dado o presumido objetivo de maximização de lucros essas firmas, na ausência de regulação estatal, tenderiam a aumentar seus preços (tarifas), atendendo apenas parte da demanda pelo serviço a preços muito superiores ao custo de prestação do serviço, além de investir em níveis inferiores ao desejado socialmente na expansão e qualidade dos serviços.

Dessa forma, é desejável que ocorra a regulação de mercados que apresentem imperfeições como a do setor elétrico, onde é inviável pela tecnologia existente que seja implementado um ambiente concorrencial. A regulação da atividade pode ser exercida (Borestein \& Camargo, 1997) com o objetivo de:

a) proibição de determinados comportamentos, isto é, vedação de certas ações expressas nos objetivos da regulação;

b) mediação, isto é, atuando como um filtro entre o público e o privado, num processo de troca ou de relação, através do agente regulador;

c) promoção, isto é, incentivo de certos comportamentos através da concessão de benefícios.

A situação de monopólio é verificada quando o mercado é constituído por apenas uma empresa. Por sua vez, a estrutura do mercado de monopólio é definida de acordo com os seguintes critérios:

a) Quanto à dimensão e número de consumidores: há um elevado número de consumidores de pequena dimensão individual no mercado, de forma que as compras de cada um são infinitesimais em relação ao volume agregado de transações; 
b) Quanto à dimensão e número de produtores: há apenas uma firma produtora ou ofertante no mercado sendo que as suas vendas representam o total do volume agregado de transações da indústria; o que faz com que a distinção entre indústria e empresa deixe de fazer sentido;

c) Quanto ao grau de substitubilidade do produto: a empresa produz um produto para o qual não há um substituto próximo;

d) Quanto às condições de entrada: há barreiras legais, tecnológicas ou outras que bloqueiam a entrada de novas empresas.

Do ponto de vista do consumidor de energia elétrica, que se relaciona diretamente com as firmas que atuam na atividade de distribuição de energia elétrica, o mercado de energia elétrica pode ser qualificado como um monopólio pois são preenchidas as condições descritas acima.

A curva de demanda de uma firma monopolista possui as mesmas propriedades gerais da curva da demanda agregada da indústria num mercado de concorrência perfeita. Ela resulta da agregação das curvas da procura ordinária individuais dos consumidores que têm inclinação negativa (à exceção dos bens inferiores). Ela pode ser expressa em sua forma inversa como Dy = Dy (Py).

A receita média do monopolista, $\mathrm{RMe}$, tal como para a empresa concorrente perfeita, coincide com a função demanda $\mathrm{RMe}=\mathrm{Py}=\mathrm{Dy}(\mathrm{Py})$. Porém, a receita marginal, RMg, é RMg = Py $-(1-1 / E)$ onde E é a elasticidade demanda-preço em sua forma direta. A curva de RMg do monopolista está sempre abaixo da curva de demanda, exceto quando o nível de produção é nulo, ou seja, Py $>$ RMg para y $>0$.

Dado que o monopolista tem como objetivo a maximização do seu lucro, no curto prazo ele só deve manter-se no mercado se conseguir cobrir os custos variáveis médios (CVMe), o que é possível tendo em vista o preço superior ao $\mathrm{CMg}$ que fixa para o seu produto.

Em uma situação de monopólio, a firma tende a ofertar sua produção a um preço superior ao seu custo marginal, fazendo com que para o consumidor haja uma perda, representada por uma menor quantidade ofertada a um nível de preço maior do que se a firma estivesse operando em uma situação de competição. 
Considerando-se que o objetivo do agente regulador é a maximização do bemestar social, deve ser buscada a otimização dos excedentes do produtor e do consumidor (Pinto Júnior \& Silveira, 1999).

Nesse contexto o excedente do consumidor, pode ser calculado como a diferença na receita a ser apropriada pela firma em função do preço máximo que o consumidor estaria disposto a adquirir de um bem e o preço a que é efetivamente adquirido. Do lado do produtor, o excedente corresponde à diferença entre o preço efetivamente recebido e o preço por unidade que seria suficiente para tornar racional sua produção e oferta (Pinto Júnior \& Silveira, 1999). Ordinariamente, com exceção da situação do chamado monopólio natural como será demonstrado, esse valor mínimo necessário à decisão de ofertar uma unidade adicional consistiria no custo marginal de produção.

Se for considerado como medida do bem estar social o excedente total, isto é, a soma dos excedentes dos consumidores e dos produtores, vê-se claramente que a passagem de uma situação concorrencial para uma situação de monopólio implica uma redução do nível de bem estar: há uma mera transferência do excedente dos consumidores na forma de renda apropriada pelo produtor monopolista, mas há também uma perda do excedente total, causada pelo menor nível de produção associado ao monopólio, que simplesmente não é apropriada nem pelo monopolista, nem pelos consumidores (o "peso morto" do monopólio, dead weight loss). $\mathrm{Na}$ situação de concorrência perfeita, não haveria excedente dos produtores, mas o excedente global (que era idêntico ao excedente dos consumidores) seria superior à soma dos excedentes do monopolista e dos consumidores sob monopólio (Fiani, 1998).

\subsubsection{Monopólio natural}

A análise da ISEB no contexto da Teoria do Monopólio deve considerar que a atividade de distribuição de energia elétrica, onde é praticada a Tarifa Social objeto do presente estudo, pode ser melhor descrita considerando-se o modelo do Monopólio Natural, demonstrando a importância que a regulação do Estado ou da Agência apresenta em indústrias que operam sob esse regime. 
A regulação de preço assume importância uma vez que a mesma pode interferir na condição de alocação do excedente de maneira a maximizá-lo. A tarefa principal do regulador consiste em fixar regras que compatibilizem o interesse dos consumidores juntamente com a garantia da firma permanecer operando, principalmente em se tratando de monopólio natural (Pinto Júnior \& Silveira, 1999).

O termo monopólio natural se refere a uma indústria se

$$
C\left(\sum_{i} Y_{i}\right)<\sum_{i} C\left(Y_{i}\right), i \geq 2
$$

Onde Yi é a produção, C(Yi) a função de custos, e i o número de firmas.

Essa condição significa que uma única firma pode produzir a quantidade demandada pelo mercado a um custo menor do que duas ou mais firmas. O caso mais comum é o monopólio natural com custos médios decrescentes. Essa configuração de mercado é comum na indústria de distribuição de energia elétrica. Existem altos custos relativos em levar a linha de distribuição de energia elétrica a um usuário, mas constante ou decrescentes custos marginais em Ihe prover o serviço. Como resultado, o custo marginal nessa atividade é constante ou decrescente, e o custo médio decrescente em relação ao aumento na produção (Vakhitova, 1998).

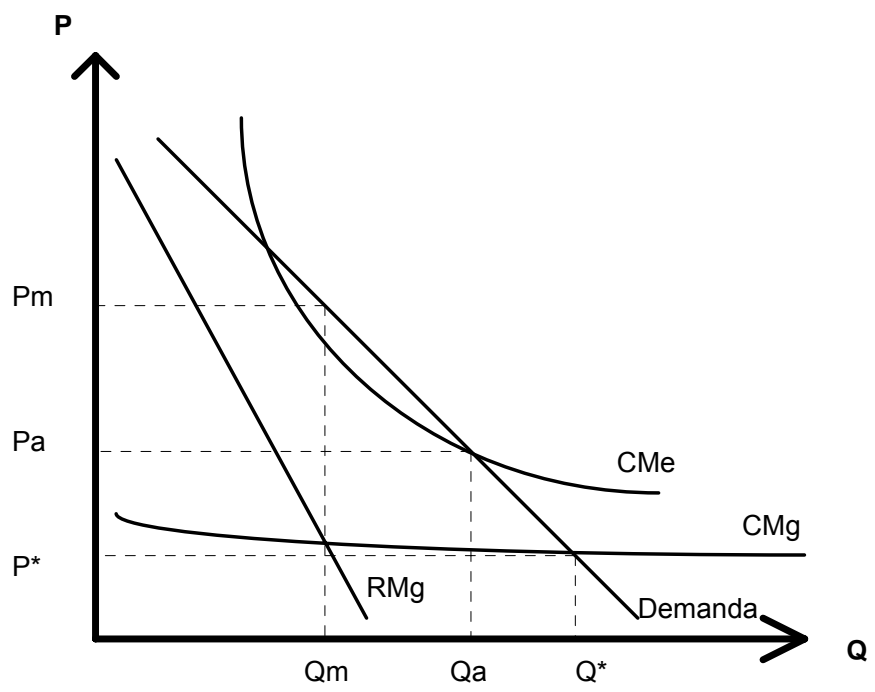

Figura 2 - Monopólio natural com custo marginal (CMg) constante. Fonte: Vakhitova (1998) 
Quando considera-se o problema da regulação do preço ou tarifa, em especial da Tarifa Social, a hipótese de que ao regulador caberia apenas fixar o preço da energia no nível do custo marginal de fornecimento é inadequada.

Em uma indústria caracterizada como um monopólio natural, entendido aquele como um monopólio em que a curva de custo médio é decrescente ao longo de toda a curva de demanda do mercado, o estabelecimento do preço aos níveis do custo marginal geraria lucros negativos para a firma, levando o monopolista a abandonar a atividade a não ser que receba subsídios que compensem esses prejuízos (Pinto Júnior \& Silveira, 1999). Por outro lado se o monopólio não é regulado, tende à ineficiência em função do preço ser superior ao custo marginal (Vakhitova, 1998).

Tratando-se de monopólio estatal é possível ajustar-se o preço ao nível do custo marginal fazendo com que o nível de bem-estar social seja privilegiado em detrimento da maximização do lucro. Essa solução foi adotada em diversos países com economias de mercado, inclusive na Grã-Bretanha, EUA e Suécia.

Tais experiências, entretanto, apresentaram poucas evidências de performances eficientes já que se caracterizaram, muitas vezes, por uma superavaliação dos custos de produção o que eliminava os potenciais ganhos dessa política, num fenômeno cuja causa é descrita pela literatura como efeito AverchJohnson.

As dificuldades na implementação da precificação com base no custo marginal, fizeram com que essa hipótese seja tida, na maioria dos países, como um referencial teórico para os demais casos (Vakhitova, 1998).

Esta situação pode ser representada na Figura 3. A quantidade $Q$ é eficiente, porém, não é lucrativa para a firma, pois a interseção entre a curva de demanda e custo marginal localiza-se abaixo da curva de custo médio. Se o regulador fixar este nível de preços, provavelmente o monopolista abandonará a atividade (Pinto Júnior \& Silveira, 1999). 


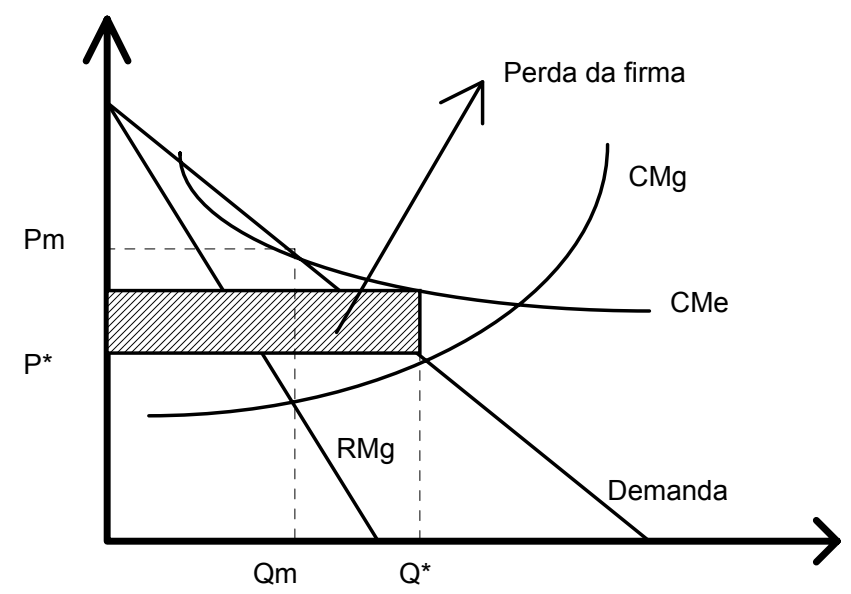

Figura 3 - Perda da firma causada pela precificação ao CMg.

Fonte: Pinto Júnior \& Silveira (1999)

A sociedade pode manter um monopólio natural operando com preço igual ao custo marginal através de subsídios (Vakhitova, 1998), numa quantidade igual ao lucro perdido. Por outro lado, alguns autores argumentam que subsidiar um monopólio privado pode ser politicamente inaceitável apesar de economicamente eficiente. Se os custos de administração são baixos e o monopólio é subsidiado através de receita tributária eficientemente fixada, a sociedade estará em uma melhor situação em relação à ausência de regulação. Nesse caso o subsídio consistiria em uma transferência de riqueza, sem implicações quanto à eficiência econômica.

Na ausência de subsídios ou transferências, a firma deverá produzir uma dada quantidade "Q" que será vendida a um preço "P" correspondente ao cruzamento da curva de custo médio e de demanda. Embora ela consiga cobrir seus custos, a quantidade é muito inferior ao que seria ótimo do ponto de vista social. Essa solução é conhecida como "segunda melhor" para um monopolista natural, por definir que os preços serão igualados aos custos médios (Pinto Júnior \& Silveira, 1999).

O estabelecimento do preço pelo custo marginal (CMg), mesmo utilizando-se o custo marginal de longo prazo (CMgLP), pode levar a dois diferentes problemas quanto à lucratividade de uma empresa elétrica em regime de monopólio: lucratividade excessiva ou a incapacidade de compensação dos custos. Esses problemas derivam do fato de que a precificação ao custo marginal não inclui os custos irrecuperáveis (sunk costs), mas representam apenas os custos adicionais incorridos com a unidade 
adicional que é demandada. Um preço que é baseado no custo marginal levará ao lucro se o custo marginal for superior ao custo médio (que incluí custos fixos e variáveis) ou ao prejuízo se o custo marginal for inferior, como ocorre no monopólio natural.

O problema dos custos irrecuperáveis, decorrente da precificação pelo custo marginal, pode inviabilizar a existência da empresa. Os altos investimentos iniciais na geração, transmissão e distribuição de energia elétrica, comparados aos relativamente pequenos custos de produção implicam necessariamente em um custo médio superior o custo marginal, resultando em prejuízos crescentes caso a precificação tenha como base o custo marginal. Nesse caso somente a concessão de subsídios pode evitar que a firma venha a interromper suas operações (Pineau, 2003).

A regulação de preço assume importância uma vez que a mesma pode interferir na condição de alocação do excedente de maneira a maximizá-lo. A tarefa principal consiste em fixar regras que compatibilizem o interesse dos consumidores juntamente com a garantia da firma permanecer operando, principalmente em se tratando de monopólio natural.

Para que o regulador estabeleça uma tarifa que beneficie tanto o consumidor como o produtor, cabe a análise tanto do nível geral de preços, como da estrutura de preços relativos para o caso de uma firma multi-produto.

Para uma firma ofertante de um único produto o regulador buscaria combinar preço e produto, de forma a maximizar o excedente total, ou seja, $\mathrm{P}=\mathrm{Cmg}$. Essa situação denomina-se "primeira melhor", ofertando Qs unidades. Porém, uma solução seria o estabelecimento da regra "segunda melhor" de maneira à torná-la financeiramente viável, igualando-se o preço ao custo médio, por exemplo.

A possibilidade de fixação do preço em função do custo médio permite que a firma opere sem incorrer em perdas. Os consumidores são beneficiados por essa precificação pois podem adquirir uma maior quantidade do bem a preços menores. Embora essa solução seja sub-eficiente - as perdas de peso morto são minimizadas a implementação dessa solução (second best) também apresenta sérias dificuldades, especialmente por exigir que o regulador seja capaz de impor que a firma opere em um nível de minimização do custo de produção, já que sua remuneração é fixada em função dos custos, em um contexto de assimetria de informações (Vakhitova, 1998). 
Para uma firma multi-produto: a solução "primeira melhor" consistiria na fixação de preço em que cada produto igualasse seu preço ao custo marginal e a "segunda melhor" seguiria a fixação de preços de Ramsey, na qual é satisfeita a restrição econômica-financeira da firma e os preços são desviados de seus custos marginais em razão inversa à elasticidade da demanda, de maneira a minimizar o peso morto da perda de bem-estar.

Dada a prática comum de impor às empresas do setor elétrico uma restrição consistente na capacidade de autofinanciamento de suas operações e instalações, uma opção de precificação com característica "second-best" pode ser desenvolvida para que as receitas necessárias sejam obtidas. Essa opção (Ramsey pricing) consiste na fixação de preços com base em custos marginais considerados em relação às diferentes elasticidades preço dos consumidores, de forma que os preços sejam baseados nos custos marginais, mas ajustados de forma que a receita total se iguale ao custo total. O fundamento dessa precificação é a discriminação entre grupos de consumidores com diferentes elasticidades preço, sendo imposto um preço mais elevado para os consumidores com demanda mais inelástica e preços menores para aqueles com demandas mais elásticas (Pineau, 2003).

Outra possibilidade de regular preços do monopólio seria a introdução de concorrência em mercados monopolizados, mesmo que em regime de monopólio natural, como forma de melhorar o bem-estar social ou, pelo menos, o bem-estar do consumidor, com a melhoria tecnológica dos serviços e a redução de preços. A implementação de concorrência em indústrias de rede consiste em permitir-se que diversas empresas possam utilizar a rede existente, pagando os encargos acrescidos à empresa inicial que possui e mantém a infra-estrutura (preços de acesso).

Os preços de acesso são hoje praticados em inúmeras indústrias que operam em rede (companhias de aviação, ferroviárias, telecomunicações, etc.) tendo sido implementadas recentemente na ISEB com a definição do "valor normativo" que permite o fornecimento de energia elétrica de forma concorrencial aos "consumidores livres". A viabilidade e utilidade desse mecanismo depende de não se deixar as infraestruturas sub-utilizadas, ficando a infra-estrutura existente à disposição da utilização de todos os concorrentes por um preço razoável.

No caso do monopólio natural, a estrutura de custos é caracterizada por economias de escala em todos os níveis da faixa relevante de produção (região até o 
ponto onde a curva de demanda de mercado cruza com uma curva de custo médio de longo prazo, $\mathrm{CMe}_{\mathrm{LP}}$ ). As indústrias de infra-estrutura são um bom exemplo de monopólio natural. No Brasil, setores de energia elétrica e telecomunicações foram desenvolvidos com uma estrutura de monopólio natural de propriedade estatal (Looty \& Szapiro, 2002).

Os setores de infra-estrutura possuíam, historicamente, uma série de características econômicas que levaram que fossem considerados monopólios naturais, pois exigem investimentos intensivos em capital e a execução dos projetos envolve longo prazo de maturação. Além disso, os serviços de infra-estrutura estão sujeitos à obrigação jurídica de fornecimento, em razão de se constituírem como serviços públicos e gerem importantes externalidades (Pires \& Piscinnini, 1999).

A literatura indica que uma das causas do monopólio natural é a apresentação de uma estrutura de custos caracterizada por economias de escala em todos os níveis da faixa relevante de produção, entendida como a região em que a curva de demanda cruza com a curva de custo médio de longo prazo - $\mathrm{Cme}_{\mathrm{LP}}$, o que implica que a escala mínima eficiente (EME) da planta é tão grande que supre toda a demanda de mercado (Looty \& Szapiro, 2002).

Os ganhos de especialização são uma das fontes das economias de escala no setor elétrico. A natureza do serviço exige mão-de-obra altamente especializada bem como bens de produção igualmente especializados, construídos sob estritos requisitos técnicos e praticamente inúteis em outras atividades que não a produção de energia elétrica (fato esse que representa os elevados custos irrecuperáveis associados a essa indústria).

A indivisibilidade técnica, compreendida como a possibilidade de expansão produtiva a taxas constantes, com CMe decrescentes, em função do uso de equipamentos anteriormente subutilizados (bens discretos) é outra fonte potencial de economias de escala verificada no setor elétrico brasileiro (Looty \& Szapiro, 2002).

Outra fonte potencial de economia de escala está diretamente associada ao tamanho da planta produtiva ("lei dos grandes números"), entendida nesse contexto como a somatória de todas as plantas das firmas que integram essa indústria, e as reduções de custos de mão-de-obra de manutenção bem como os estoques de peças de reposição, sendo ainda relevante a diminuição de custos com a manutenção de 
capacidade de reserva a ser utilizada em momentos de manutenção ou de falha no processo produtivo (Looty \& Szapiro, 2002).

No planejamento da operação do sistema hidrolelétrico brasileiro, por exemplo, seja na fase estatal ou privada, adotou-se por um longo período o conceito de "energia firme" (capacidade mínima de geração garantida tecnicamente e inferior à capacidade plena de produção) como variável relevante no planejamento do setor. Esse conceito representa a prática de manter-se, ao menos, uma turbina de reserva nas UHEs, que somente entra em operação na hipótese de manutenção ou falhas em outras turbinas o que significa, também, que raramente as UHEs produzem energia elétrica em sua capacidade plena.

Essa característica de operação interligada, típica de uma indústria em rede, permite a obtenção de economias de escala relacionadas ao aspecto multiplanta do setor elétrico e de especialização de produção nas diferentes plantas.

A capacidade de alternância entre geração hidrelétrica e termelétrica é uma possível fonte de economias de escala ao nível multiplanta decorrente da possibilidade de flexibilização da operação, possibilitada pela capacidade de compensação do fluxo produtivo entre as múltiplas plantas, no caso de ocorrência de flutuações produtivas entre as mesmas, ou no caso de redução da demanda, quando é possível interromper a operação das plantas de maior custo, utilizando a capacidade instalada de modo mais eficiente (Looty \& Szapiro, 2002).

\subsubsection{Monopólio maximizador de quantidade}

Outra característica relevante da ISEB relevante para o presente estudo, especialmente na fase em que esteve majoritariamente sob controle estatal, quanto à forma de operação do sistema elétrico brasileiro é que o mesmo adota um comportamento equivalente ao de um monopólio maximizador de quantidade.

Essa hipótese teórica implica que o monopolista não oferte a quantidade corresponde ao trecho elástico da curva de demanda (hipótese na qual estaria maximizando seu lucro), operando no trecho inelástico, próximo à quantidade total demandada pelo mercado. A opção desse modelo é pela produção relacionada com a 
maior receita total que satisfaça um lucro mínimo, embora um nível menor de receita possa gerar o lucro máximo.

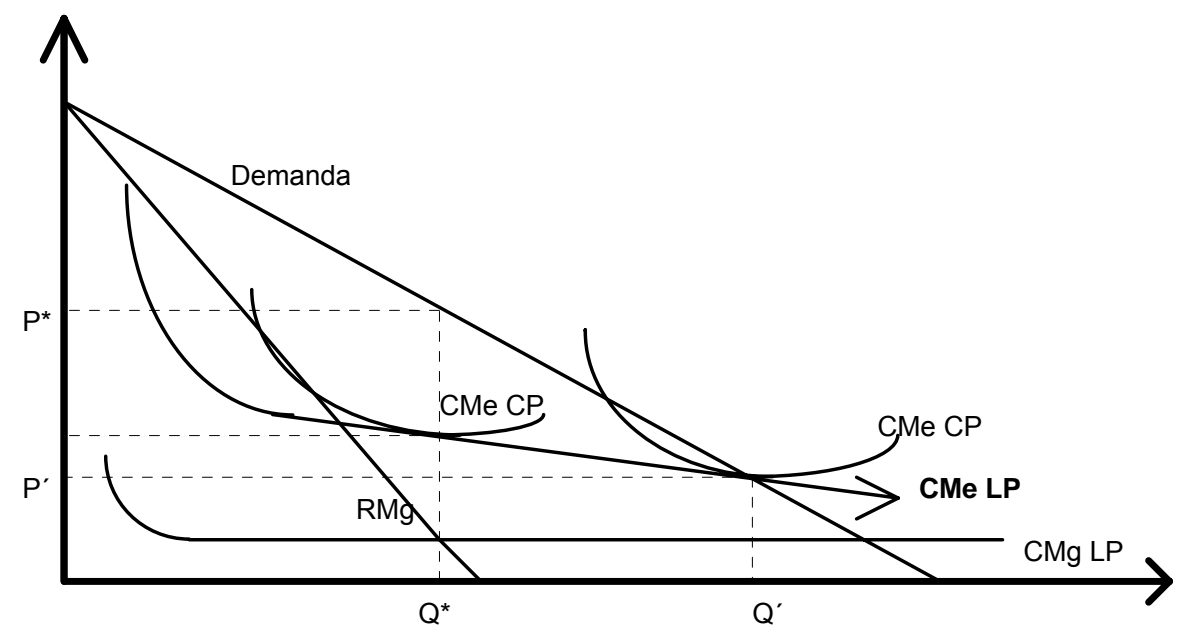

Figura 4 - Monopólio Maximizador de quantidade.

Fonte: Frank (1997)

\subsubsection{Discriminação de preços}

Uma forma diferenciada de regulação dos preços que são praticados por uma firma em situação de monopólio natural é permitir que o monopólio natural pratique a discriminação de preços.

A discriminação de preços pode ser definida como a prática de diferentes preços para diferentes consumidores que adquirem o mesmo bem, sendo que os custos de produção desse bem para ambos consumidores seja idêntico, ou ainda, mesmo que os custos variem, a diferenciação no preço supere a variação dos custos.

Formalmente, a discriminação de preços consiste em:

$$
\frac{p_{k}}{C M g_{k}} \neq \frac{p_{n}}{C M g_{n}}
$$

Onde $\mathrm{P}$ é preço, $\mathrm{CMg}$ representa o custo marginal, $\mathrm{K}$ e $\mathrm{N}$ definem dois diferentes segmentos de mercado (Vakhitova, 1998). 
$\mathrm{Na}$ teoria econômica define-se três tipos de discriminação de preços. A discriminação de primeiro grau, ou discriminação de preço perfeita, implica que de cada consumidor é cobrado o seu preço de reserva para o bem, o que permite ao monopolista capturar todo o excedente do consumidor. A discriminação de preços de segundo e terceiro graus se referem à discriminação imperfeita, em que o monopolista pode capturar apenas parte do excedente do consumidor (Vakhitova, 1998). A discriminação de preços de segundo grau consiste na prática de impor preços diferentes para cada unidade do mesmo produto, dependendo de quantas unidades o consumidor adquira (tarifação decrescente por blocos, tarifa de duas partes etc.).

O monopolista pode discriminar preços de diversas formas:

a) em relação a cada consumidor e a cada unidade vendida para um mesmo consumidor (discriminação de primeiro grau) esgotando todo seu excedente através do conhecimento perfeito da propensão a pagar de cada consumidor, por cada unidade do bem;

b) em relação ao número de unidades vendidas para um mesmo consumidor (discriminação de segundo grau), através da cobrança de preços diferentes por unidades vendidas para um mesmo consumidor. Nessa forma de discriminação de preços cada quantidade é vendida por um mesmo preço para todos os consumidores;

c) em relação aos diferentes consumidores (discriminação de terceiro grau) através da cobrança de preços diferentes para diferentes consumidores, mas cobrando-se um mesmo preço por todas as unidades vendidas para um mesmo consumidor;

Considerando-se o custo marginal (CMg) constante, a perda de peso morto de um monopólio com preço único pode ser assim representada: 


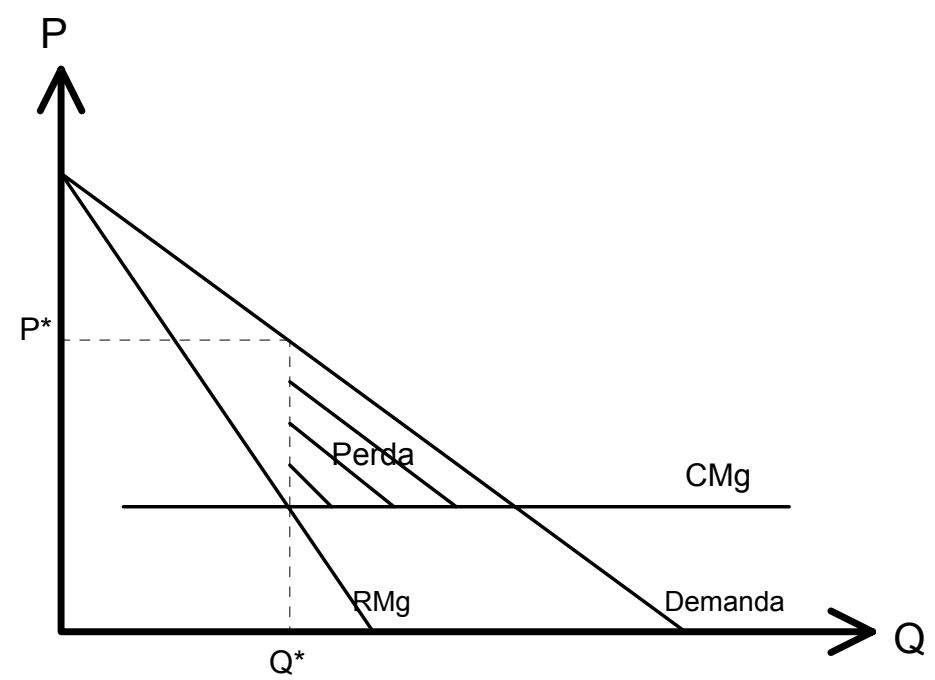

Figura 5 - Perda de peso morto e monopólio de preço único.

Fonte: adaptado de Varian (1999)

A possibilidade do monopolista segmentar o mercado através da imposição de uma barreira permite que a imposição de um preço mais elevado $\left(P_{H}\right)$ aos consumidores de alta renda, vendendo a quantidade $\left(Q_{H}\right)$ e um preço reduzido $\left(P_{L}\right)$ aos consumidores de baixa renda, vendendo a quantidade $\left(Q_{H}+Q_{L}\right)$. Nessa hipótese a perda de peso morto $(\mathbf{W})$ é reduzida

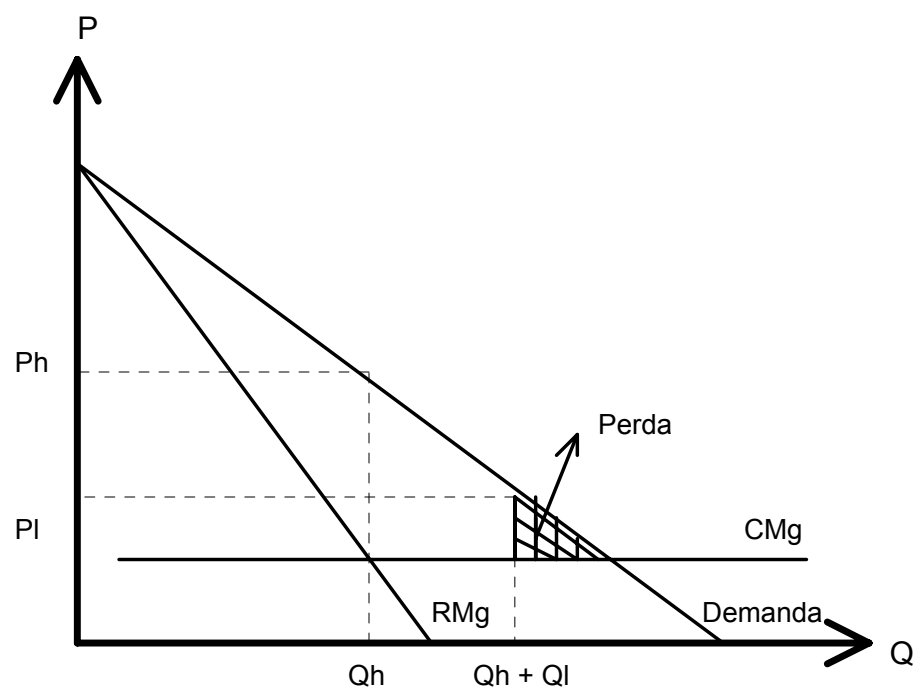

Figura 6 - Perda de peso morto e monopólio com dois preços.

Fonte: adaptado de Varian (1999) 
A discriminação de preços é possível e lucrativa nas seguintes condições:

a) a empresa deve ser fixadora do preço - neste caso, enfrenta uma procura negativamente inclinada, podendo cobrar preços diferentes a clientes diferentes;

b) a empresa necessita identificar o perfil da procura de cada consumidor potencial e

c) os consumidores não podem desenvolver atividades de arbitragem, comprando o bem num mercado a preços mais baixos para revenda noutro mercado a preços mais elevados.

Para que haja discriminação de preços um mesmo produto tem que ser vendido a diferentes preços para diferentes compradores. O custo de produção é o do monopolista, isto é, o mesmo para todos os produtos vendidos. O produto é idêntico, os consumidores não percebem qualquer diferença nos produtos vendidos.

A discriminação de preços vai depender da renda dos consumidores, das suas preferências, da localização e da facilidade de encontrar substitutos para o produto, além do conhecimento pelo monopolista das preferências e propensões a pagar dos consumidores.

O poder do monopolista permite que ele tenha uma política de discriminação de preços voltada para extrair o máximo possível de excedente do consumidor e para aumentar a sua receita total. Os serviços pessoais são raramente transferíveis e a sua venda faculta freqüentemente uma oportunidade para fazer discriminação pelo preço. Por sua vez, a revenda de eletricidade - que requer mecanismos de transferência, sejam redes de distribuição ou de transmissão - é extremamente difícil, inviabilizando a sua aplicação, além de ser ilegal. A discriminação de preço pode, então, ser praticada na fixação dos preços, refletindo diferentes custos marginais em diferentes períodos (por exemplo, tarifas mais elevadas em "períodos de ponta", ou tarifas reduzidas para grandes consumidores).

\subsubsection{Discriminação de preços de $1^{\circ}$ grau}

A discriminação de preços de primeiro grau consiste no comportamento adotado pelo monopolista que cobra preços diferentes para as várias unidades 
consumidas de um bem, diferenciando também em relação aos diferentes consumidores, de acordo com sua disposição a pagar do(s) consumidor(es), fixando o preço do bem ao nível do preço de reserva do consumidor.

Como cada ponto de uma curva da procura representa o preço mais elevado que os consumidores estão dispostos a pagar para a quantidade correspondente do produto se, por simplicidade, supusermos que os efeitos-rendimentos são nulos, então, as curvas da procura ordinária e compensadas coincidem e o excedente do consumidor corresponderá à área entre a curva da procura e o preço pago pelos consumidores para a quantidade transacionada no mercado.

Em certos casos, o monopolista é capaz de segmentar o seu mercado de modo a vender cada unidade adicional do bem ao montante máximo que os consumidores estão dispostos a pagar.

A condição de $1 .^{a}$ ordem de maximização do lucro da discriminação de preços de primeira ordem é equivalente à condição de concorrência perfeita, com a diferença que, agora, o preço não é constante, mas é dado pela função procura. Daqui se conclui que, no caso de discriminação perfeita, a $R M g$ é igual à função procura. Da condição de 2. ${ }^{a}$ ordem resulta que a inclinação da curva do custo marginal deverá ser maior do que a da curva da procura.

O monopolista que pratica discriminação de primeiro grau maximiza o seu lucro vendendo a quantidade que corresponde à intersecção entre a curva da procura e a curva do custo marginal. O preço praticado não é um preço uniforme mas varia ao longo da curva da procura de forma que o monopolista consegue absorver todo o excedente do(s) consumidor(es). Essa precificação faz com que o nível do produto ofertado seja idêntico ao que seria ofertado na presença de concorrência, o que implica em uma transferência de excedentes dos consumidores ao produtor, sem que seja causada distorção quanto à eficiência (Vakhitova, 1998).

As outras formas de discriminação de preço não implicam nesse resultado pois, dependendo dos formatos das curvas de demanda e de custos, a discriminação de preços pode ser melhor ou pior do que o preço de monopólio, sob o ponto de vista da eficiência. Há duas possíveis fontes de ineficiência, sendo a primeira uma diminuição no nível do produto e a segunda associada ao consumo (Vakhitova, 1998) situações que serão abordadas em seguida. 


\subsubsection{Discriminação de preços de $2^{\circ}$ grau}

Na discriminação de preços de segunda ordem o monopolista vende diferentes unidades do produto a preços diferentes, mas todos os compradores que adquirem a mesma quantidade pagam o mesmo preço. O preço por unidade não é constante, depende da quantidade que o consumidor compra. Os preços estabelecidos pelo monopolista têm um comportamento não-linear (Melo, 2002).

Trata-se de um caso de discriminação de preços que pressupõe patamares de preços cobrados aos consumidores consoante o seu nível de consumo. Assim, por exemplo, as empresas distribuidoras de eletricidade fixam tarifas por escalões de consumo aos clientes industriais, diminuindo a tarifa cobrada de cada unidade de energia à medida que seu consumo total aumenta. A discriminação de preços de segundo grau, por outro lado, não parece ser uma solução adequada ao problema do monopólio natural pois pode induzir ao consumo excessivo (Vakhitova, 1998).

\subsubsection{Discriminação de preços de $3^{\circ} \mathrm{grau}$}

A discriminação de preços de terceiro grau consiste no comportamento do monopolista que vende o produto para diferentes compradores por preços diferentes, mas cada unidade vendida para um grupo de compradores é vendida ao mesmo preço (Melo, 2002).

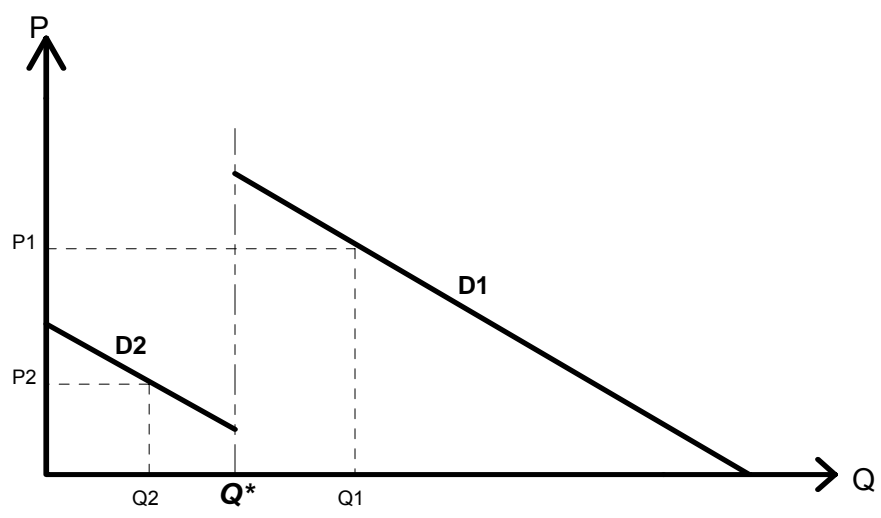

Figura 7 - Diferenciação da demanda e preço em função da renda.

Fonte: adaptado de Araújo (1997)

D1- Demanda de consumidores com renda alta

D2- Demanda de consumidores com renda baixa

Q*- Quantidade limite 
Para que seja implementada essa prática (Vakhitova, 1998) é necessário que:

a) diferentes segmentos de mercado possam ser claramente identificados;

b) cada segmento de mercado apresente diferentes elasticidade preço demanda;

c) seja impossível a arbitragem.

A discriminação de preços de terceiro grau pode ser representada graficamente, considerando D1 e D2 as curvas de demanda de dois mercados distintos, e as respectivas curvas de receita marginal Rmg1 e Rmg2.

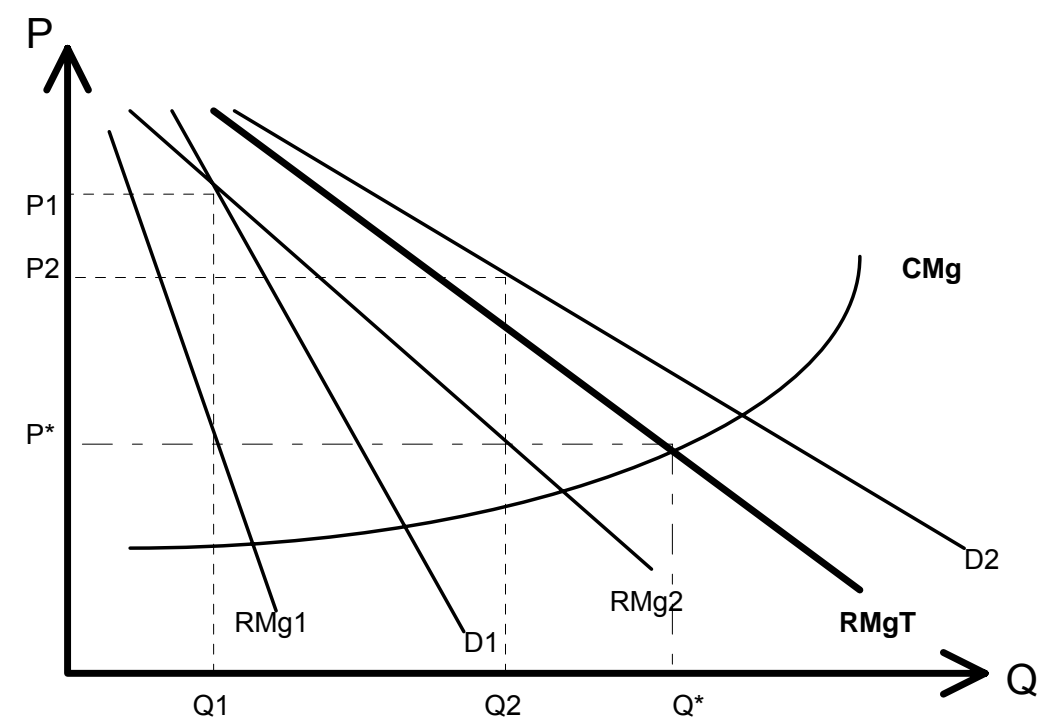

Figura 8 - Discriminação de preços (P1 e P2).

Fonte: adaptado de Vakhitova (1998)

Nessa situação as curvas de receita marginal podem ser somadas horizontalmente para obter-se RmgT. A produção será dada pelo ponto onde a receita marginal total RmgT se iguala ao custo marginal (CMg). Essa quantidade de produto será ofertada nos dois diferentes segmentos de mercado aos preços P1 e P2, onde as receitas marginais são iguais (Vakhitova, 1998).

Essa solução pode ser representada algebricamente, considerando-se que a curva de demanda de cada sub-mercado pode ser representada como: 


$$
\begin{aligned}
& q_{1}=D_{1}\left(p_{1}\right) \\
& q_{2}=D_{2}\left(p_{2}\right)
\end{aligned}
$$

Onde qi: produção vendida para o sub-mercado da classe $i(i=1,2)$ e pi é o preço cobrado no sub-mercado da classe. Agregando-se essas curvas, a curva de demanda total do mercado consiste em

$$
q=D_{1}(p)+D_{2}(p)
$$

A curva de demanda inversa de cada classe pode ser expressa como

$$
\begin{aligned}
& p_{1}=p_{1}\left(q_{1}\right) \equiv D_{1}^{-1}\left(q_{1}\right) \\
& p_{2}=p_{2}\left(q_{2}\right) \equiv D_{2}^{-1}\left(q_{2}\right)
\end{aligned}
$$

Considera-se uma estrutura de custos, receitas e lucro como

Receitas:

$$
\begin{aligned}
& R T_{1}\left(q_{1}\right) \equiv p_{1}\left(q_{1}\right) q_{1} \\
& R T_{2}\left(q_{2}\right) \equiv p_{2}\left(q_{2}\right) q_{2} \\
& R T\left(q_{1}, q_{2}\right) \equiv R T_{1}\left(q_{1}\right)+R T_{2}\left(q_{2}\right)
\end{aligned}
$$

Custos:

$$
\begin{aligned}
& C T\left(q_{1}, q_{2}\right)=C T\left(q_{1}+q_{2}\right)=C T(q) \\
& q \equiv q_{1}+q_{2}
\end{aligned}
$$

Lucro:

$$
\begin{aligned}
& \Pi\left(q_{1}, q_{2}\right)=R T\left(q_{1}, q_{2}\right)-C T\left(q_{1}, q_{2}\right) \\
& =R T_{1}\left(q_{1}\right)+R T_{2}\left(q_{2}\right)-C T\left(q_{1}+q_{2}\right)
\end{aligned}
$$

O problema da firma monopolista pode ser expresso como encontrar $\left(q_{1}^{M}, q_{2}^{M}\right)$ tal que:

$$
\left(q_{1}^{M}, q_{2}^{M}\right)=\underset{q_{1}, q_{2}}{\arg \max } \Pi\left(q_{1}, q_{2}\right)
$$


Condição de maximização de $1^{\mathrm{a}}$ ordem:

$$
\begin{aligned}
& \frac{\partial \Pi\left(q_{1}^{M}, q_{2}^{M}\right)}{\partial q_{1}}=\frac{\partial R T_{1}\left(q_{1}^{M}\right)}{\partial q_{1}}-\frac{\partial C T\left(q_{1}^{M}+q_{2}^{M}\right)}{\partial q}=0 \\
& \frac{\partial \Pi\left(q_{1}^{M}, q_{2}^{M}\right)}{\partial q_{2}}=\frac{\partial R T_{2}\left(q_{2}^{M}\right)}{\partial q_{2}}-\frac{\partial C T\left(q_{1}^{M}+q_{2}^{M}\right)}{\partial q}=0
\end{aligned}
$$

Esse resultado indica que para atingir a maximização do lucro através da discriminação de preços o preço mais alto é cobrado da classe com menor elasticidade preço-demanda, ou seja

$$
\left|\varepsilon_{1}^{M}\right|>\left|\varepsilon_{2}^{M}\right|
$$

A discriminação de preços permite a obtenção de receita muito superior àquela que seria obtida através de um sistema de preço único. Existem algumas situações em que os custos de produção são tão elevados que a receita não pode cobri-los a não ser que a discriminação esteja envolvida.

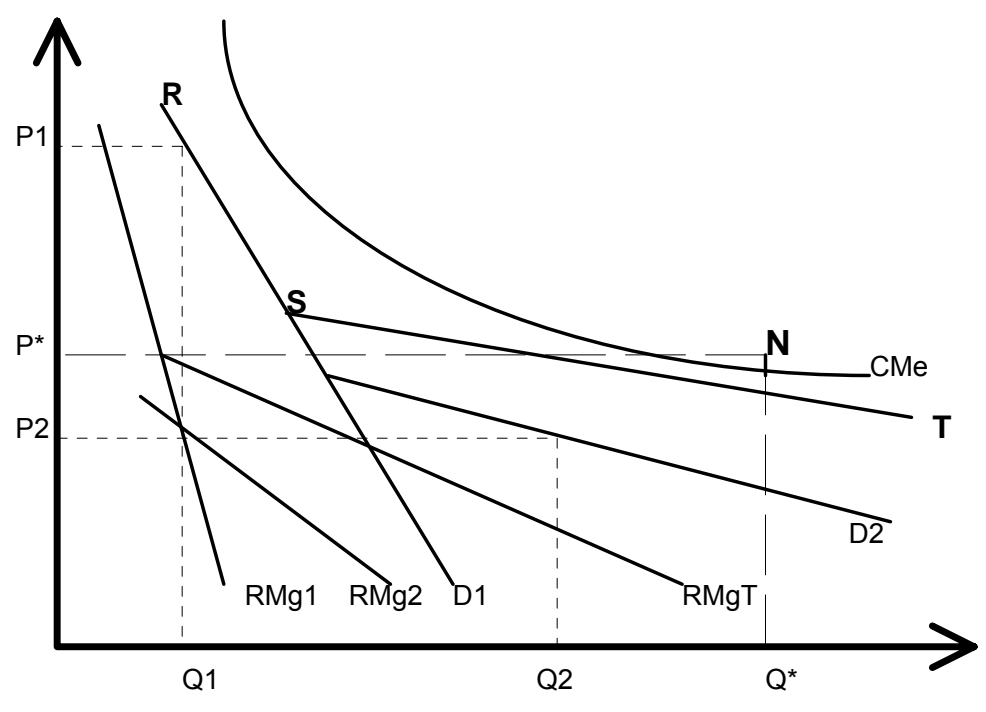

Figura 9 - Discriminação de preço como forma de viabilização da firma.

Fonte: adaptado de Vakhitova (1998)

RST: Curva de demanda total

$\mathrm{Q}^{*}=\mathrm{Q} 1+\mathrm{Q} 2$

$\mathrm{P}^{*}=$ preço médio 
Essa hipótese pode ser apresentada como um mercado com duas classes de consumidores e suas respectivas curvas de demanda para um determinado bem, D1 e D2. Somando essas duas curvas obtém-se a curva de demanda total RT. Sem discriminação de preços, não haveria produção pois em qualquer nível de produto o preço seria superior ao custo médio descrito como curva $\mathrm{CMe}$. Com a discriminação de preços, uma quantidade Q1 poderia ser vendida ao preço P1, outra quantidade Q2 poderia ser vendida ao preço $P 2$, e a quantidade total $Q^{*}=Q 1+Q 2$ produz a receita total OQ*NP3, ao preço médio P3 (Vakhitova, 1998). Em situações como essa a discriminação de preços pode ser uma solução apropriada ao problema do monopólio natural.

A relevância da possibilidade de discriminação de preços para o monopólio é que é possível que o produto total aumente, o que implicaria no aumento da eficiência. Se o produto permanecer constante ou diminuir quando a discriminação de preços é implementada, o bem-estar total diminuirá, significando que o aumento no produto deve ser grande o suficiente para superar a ineficiência do consumo. A discriminação de preços de terceiro grau, particularmente, pode beneficiar a sociedade quando permite que um pequeno mercado seja servido, que, de outra forma, sequer existiria (Vakhitova, 1998). A discriminação de preços de segunda ordem, por outro lado, com preços decrescentes para maiores quantidades, pode consistir num estímulo ao consumo excessivo.

\subsection{Modelos tarifários da ISEB}

Alguns dos principais objetivos da regulação são:

a) garantir simultaneamente preços baixos e elevados níveis de produção;

b) resolver as tensões entre eficiência alocativa, distributiva e produtiva; e

c) incorporar mecanismos de indução à eficiência dinâmica;

Para atingi-los um dos meios mais utilizados é o estabelecimento de políticas de tarifação ajustadas aos objetivos regulatórios que são fixados pela legislação ou pelo Governo. Outros meios utilizados freqüentemente incluem a definição de uma legislação de proteção ao consumidor, uma legislação anti-truste, padrões mínimos de qualidade do serviço e a definição de recompensas pelo cumprimento de metas de preço ou de expansão do serviço, ou punições às condutas inadequadas da firma. 
No presente estudo a análise dos instrumentos regulatórios será descritiva, elencando as principais técnicas utilizadas internacionalmente e concentrada na análise de políticas tarifárias implementadas na ISEB, especificamente nas tarifas finais praticadas pelo sistema de distribuição de energia. Tais políticas tarifárias consistem na definição na forma de remuneração das firmas atuantes na ISEB e permitem a definição da tarifa normal, sobre a qual é calculada a Tarifa Social através da aplicação de descontos. Pode-se verificar que a evolução histórica das diferentes políticas tarifárias consistiu em um aperfeiçoamento na forma de contabilização dos custos incorridos pelas firmas, a forma de controle sobre preços finais, e a forma atual que representa uma mescla dos dois sistemas, implementada pela ANEEL em 2003 sobre a ISEB.

\subsubsection{Modelos baseados no custo}

Segundo o método do "custo histórico" para a definição da remuneração das firmas, os ativos utilizados na prestação do serviço são valorizados a partir do seu valor original de compra. Por esse método, busca-se garantir à firma a remuneração em função do custo de oportunidade do capital investido na prestação do serviço, sendo que essa taxa ou percentual seria definido na legislação ou pelo ente regulador, segundo a taxa média ou "justa" de remuneração que esse mesmo capital renderia em outras atividades econômicas.

No entanto, apesar de apresentar praticidade esse método não considera o princípio da eficiência alocativa, levando a distorções, como a perda da relação entre o valor do ativo das firmas e o custo que um novo participante no mercado incorreria para instalar uma rede e prestar serviços similares aos prestados pela empresa regulada. Esta distorção pode ser causada pela inflação - no caso em que o valor do ativo regulatório estaria sub-avaliado - ou pelo progresso tecnológico - situação em que o valor dos ativos regulatórios estariam superavaliados.

Neste procedimento, fixa-se a taxa de remuneração do capital investido e as tarifas são calculadas de modo a satisfazer essa taxa, para um nível de consumo previsto.

Uma característica central deste procedimento é que a Base de Capital inclui apenas investimentos efetivamente realizados no passado. Um dos efeitos adversos 
quanto à eficiência que podem decorrer dessa modalidade tarifária é o estímulo à firma a um sobre-investimento em bens de capital, em detrimento da investimentos no capital humano necessário para realizar a mesma atividade de forma eficiente.

Esse sistema foi utilizado na ISEB a partir de 1934, com a prévia nacionalização de diversas empresas e a edição do Código de Águas. A preocupação deste diploma legal era de impor uma tarifa "neutra", por expressar os custos do sistema e cobrar uma tarifa eqüitativa, no sentido de que a cada grupo de consumidor fosse atribuído a fração equivalente do custo do serviço prestado (Barbosa, 1991).

O Código de Águas estabeleceu que o custo compreenderia :

a) todas as despesas de operações, impostos e taxas de qualquer natureza, lançadas sobre a empresa, excluídas as taxas de benefícios;

b) as reservas para depreciação, e

c) a remuneração de capital da empresa.

A avaliação do capital efetivamente utilizado pela empresa, menos a depreciação, devia ser calculada ao "custo histórico", sem permitir que o seu valor nominal fosse corrigido de acordo com a inflação. Segundo Barbosa (1991), essa situação anômala só foi mudada cerca de trinta anos depois, em 1964, quando se permitiu a correção monetária do ativo imobilizado, para o cálculo do investimento remunerável, protegendo os investimentos no setor de energia elétrica da corrosão inflacionária.

O aspecto negativo desse modelo de determinação das tarifas, decorria do fato de que a firma possuía mais informações que o órgão regulador sobre a sua estrutura de custos e características da demanda. A cada período o órgão regulador, a partir dos dados contábeis, da política de depreciação e da inflação no período, fixava níveis tarifários sob dadas hipóteses de comportamento da demanda (Araújo, 1997).

O método do "custo corrente" implementado na ISEB constitui em um refinamento do método do custo histórico baseado na utilização de ajustes ao valor contábil histórico para refletir a inflação, subtraída a depreciação.

Esse método também era objetivo o suficiente para não desestimular o investimento pelos concessionários privados, além de preservar 0 valor do investimento e da sustentabilidade financeira da concessionária. 
Entretanto, essa política tarifária pode conduzir a distorções na medida em que também não considera critérios de eficiência alocativa (distorção tecnológica) e pela possibilidade de super-avaliação de ativos defasados tecnologicamente em virtude da correção pela inflação.

O método do "custo de reposição" estabelece que o valor de cada ativo é dado pelo custo corrente de substituí-lo por outro bem que efetue os mesmos serviços e tenha a mesma capacidade do ativo existente. A diferenciação em relação os métodos do custo histórico e corrente é que o capital utilizado pela firma na prestação do serviço não é avaliado pelo que custou no passado, mas sim pelo custo de equipamentos mais modernos. Da mesma forma que o método do custo corrente representou um avanço sobre uma das falhas do método do custo histórico (efeito da inflação e depreciação sobre os ativos) o método do custo de reposição buscou suprir a outra falha do método do custo histórico com a incorporação da variável tecnológica, buscando refletir os ganhos de produtividade obtidos com o avanço tecnológico.

O método do "custo de serviço" consiste em fixar uma taxa de remuneração do capital investido, considerada "justa" pelo regulador em função dos custos de prestação do serviço e não do valor dos ativos empregados na prestação do serviço, como no método do custo histórico e dos métodos dele derivados. Sob essa política tarifária as tarifas são calculadas baseadas nesta taxa de remuneração, dado um nível de consumo (comportamento da demanda) previsto. Compete à firma definir os insumos a serem utilizados e executar suas decisões quanto a outros custos e receitas à qual a sua taxa de retorno não exceda a taxa estipulada. Assim, o preço do serviço é dado no ponto onde a curva de demanda encontra a curva de custo médio (Pinto Júnior \& Silveira, 1999) conforme o modelo "second-best" descrito na literatura.

No cálculo da tarifa eram consideradas as seguintes parcelas do investimento total (Barbosa, 1991): a) os bens e instalações em efetiva operação ou utilização no serviço; b) os materiais de almoxarifado, indispensáveis ao funcionamento ou à expansão do sistema elétrico e à administração da empresa; c) o capital de giro necessário à movimentação da empresa. O investimento remunerável era igual à diferença entre o investimento total e a soma das seguintes deduções: a) reserva para depreciação; b) a reserva de amortização, se houver; c) os adiantamentos, contribuições e doações referentes aos bens e instalações incluídos no investimento total; d) o valor das obras pioneiras dos bens e instalações para uso futuro e de 
propriedade da união em regime especial de utilização e e) o saldo da Conta de Resultados a compensar.

O preço estipulado pelo regulador não deveria exceder o total dos custos e da taxa de retorno fixada legalmente, por unidade produzida. Este cálculo revelou-se bastante complexo, pois, a cada período, a partir dos resultados contábeis, a política de depreciação vigente e a inflação do período, o regulador deveria fixar as tarifas. Essa complexidade não impediu a implementação dessa política tarifária, especialmente no período em que a ISEB estava sob controle estatal direto e, supostamente, o regulador conheceria as estruturas de custos das firmas, superandose com relativo sucesso as conseqüência do efeito Averch-Johnson.

Os ativos detidos ou pretendidos pela firma para expansão ou modernização do serviço não seriam considerados no cálculo da remuneração a ser obtida via tarifária; a não ser como exceção ao sistema, desde que se provassem absolutamente necessários sob critério do ente regulador, o que permitiria o repasse às tarifas (Pinto Júnior \& Silveira, 1999).

A diferença entre a remuneração resultante da aplicação do valor percentual aprovado pelo Poder Concedente e a efetivamente verificada no resultado do exercício era registrada na Conta de Resultados a Compensar, do concessionário, para fim de compensação dos excessos e insuficiência de remuneração.

No cálculo do custo do serviço também era computada uma quota anual de $5 \%$ sobre o investimento total, depositados em duodécimos, em duas contas da Eletrobrás, a conta denominada Reserva Global de Reversão que fica com $60 \%$ da quota, e os $40 \%$ restantes que são destinados à conta Reserva Global de Garantia, que foi substituída posteriormente pela Conta Reserva Nacional de Compensação de Remuneração (RENCOR). A Eletrobrás podia movimentar a primeira conta para aplicação em casos de reversão, de encampação de serviços públicos de energia elétrica, ou em empréstimos a concessionárias para expansão dos respectivos serviços. A Conta da Reserva de Garantia provia recursos para a garantia do equilíbrio econômico e financeiro das concessões, sendo movimentada pela Eletrobrás, sob expressa determinação do DNAEE (Barbosa, 1991).

A equalização tarifária da energia elétrica em todo o território nacional, estabelecida em 1974, implicou em uma violação desse sistema em relação às firmas, 
ao dissociar a tarifa do custo do serviço. Porém a coerência do modelo foi mantida no nível agregado da ISEB, pois eram considerados os custos agregados do serviço e as tarifas idênticas de todas as firmas.

A implementação desta política de equalização acarretou mudanças na metodologia de cálculo das tarifas feitas pelo DNAEE. Cada empresa de energia elétrica possuía uma estrutura tarifária por nível de tensão, que refletia seus custos.

O DNAEE considerou, então, que no regime de tarifas equalizadas não havia necessidade de cada empresa fazer seus cálculos de custos, pois o problema de cada empresa resumia-se agora à obtenção ou não de cobertura de seus custos globais, a partir da receita das tarifas.

As empresas passaram a apresentar não mais o roteiro dos custos por nível de tensão, mas sim seus custos globais. A partir desses dados o DNAEE equiparou gradativamente as tarifas das empresas. Entretanto, ficou mantida a classificação dos consumidores por nível de tensão. Conseqüentemente, as tarifas por nível de tensão sofreram afastamentos inevitáveis com relação ao princípio do serviço pelo custo para cada grupo de consumidor (Barbosa, 1991).

A tarifa de suprimento inter-setorial passou a ser o vaso comunicante na distribuição dos recursos financeiros. Nos casos em que este procedimento era insuficiente para a rentabilidade da empresa, usava-se a conta Reserva Global de Garantia (RGG), que deixou de ser um percentual sobre o valor das instalações e passou a ser determinada sobre a diferença positiva entre a remuneração da empresa e a remuneração média do setor elétrico (Barbosa, 1991).

Este dispositivo possibilitou a transferência de um volume maior de recursos através da conta RGG, retirando-se das tarifas de suprimento o papel de vasos comunicantes dos recursos financeiros do setor elétrico. A equalização tarifária provocou transferências de rendas das regiões com empresas que produziam energia elétrica de maneira mais eficiente a custos mais baixos, para empresas com custos mais altos.

A preocupação de estabelecer preços não-discriminatórios fez com que, durante muito tempo, o regime tarifário pelo custo do serviço não abordasse devidamente as diferenças de custos existentes com relação às diversas categorias de consumidores, resultando em ineficiências alocativas. Se, por um lado, esse critério 
tinha um apelo social ao buscar preservar a garantia de universalidade e igualdade de tratamento entre os consumidores, por outro, arbitrava aleatoriamente a distribuição dos custos dos serviços prestados entre eles em função da eficiência da firma que os atendia (Pires \& Piccinini, 1998).

\subsubsection{Modelo baseado no preço teto (price cap)}

Dentre os mecanismos de tarifação, o mecanismo do "price-cap" (ou "preçolimite") é adotado atualmente no Brasil, bem como em diversos países. O mecanismo de price cap tem por objetivo estabelecer estímulos à eficiência produtiva, uma vez que confere ao regulador o poder de definir um teto para os preços médios ou de cada produto da firma (Salgado, 2003), corrigido-os de acordo com a evolução de um índice de preços aos consumidores, subtraído de um percentual equivalente ao fator de produtividade, para um período prefixado de anos.

A percepção de que os modelos tarifários baseados nos custos das firmas geravam, entre outros, problemas derivados da assimetria de informação entre a firma regulada e o órgão regulador (efeito Averch-Johnson) fez com que esquemas alternativos de regulação fossem criados.

Estes métodos buscam a regulação por incentivos, implementando-se regras que induzam as firmas reguladas a atingir metas desejáveis, através da concessão de algum direito (Pinto Júnior \& Silveira, 1999). As tarifas seriam reajustadas em um nível inferior ao da inflação quando a taxa de retorno excedesse uma taxa limite, sendo esse ajuste parcial, para que a firma fique com parte do lucro realizado em decorrência dos ganhos de produtividade que conseguisse obter.

As razões apontadas pela literatura para adotar esse mecanismo envolvem a busca a redução dos riscos e dos custos da ação reguladora, dispensando-a de controles que necessitem de informações sobre os custos das firmas reguladas.

O price cap é apontado na literatura como um método tarifário adequado para as empresas em regime de monopólio natural, além de estimular ganhos de produtividade e sua transferência parcial para os consumidores (Salgado, 2003).

O preço é fixado juntamente com uma fórmula para a execução de reajustes. $\mathrm{Na}$ fórmula consta a inflação medida no período, um termo referente ao ganho de 
produtividade e um termo aleatório, no caso de contingências não esperadas (Pinto Júnior \& Silveira, 1999).

A principal diferença para a regulação dita tradicional consiste na separação entre os custos e preços. Significa dizer que, mesmo na presença de assimetrias de informação, a firma regulada procurará reduzir seus custos, pois, uma vez que os preços não são determinados pelos custos adicionais incorridos, a firma regulada poderá aumentar seu lucro através do corte de custos sem que haja uma queda automática nos preços (Pinto Júnior \& Silveira, 1999).

\begin{tabular}{|c|c|c|}
\hline Tipo de Regulação & $\begin{array}{c}\text { Taxas de Retorno (remuneração } \\
\text { com base nos custos) }\end{array}$ & $\begin{array}{c}\text { Price-cap (remuneração com } \\
\text { base em preço limite) }\end{array}$ \\
\hline $\begin{array}{c}\text { Objetivos/ } \\
\text { Características }\end{array}$ & $\begin{array}{l}\text { Assegurar o reajuste de preços que } \\
\text { permita o reembolso integral dos } \\
\text { custos. }\end{array}$ & $\begin{array}{c}\text { Assegurar um preço teto, menos } \\
\text { um índice negociável } \mathrm{X} \text {, fixado } \\
\text { exante (indicador de } \\
\text { produtividade RPI-X). }\end{array}$ \\
\hline Vantagens & $\begin{array}{l}\text { Assegurar a viabilidade econômica } \\
\text { da firma; } \\
\text { Incitar o investimento, aspecto } \\
\text { importante em fase de forte } \\
\text { expansão. }\end{array}$ & $\begin{array}{l}\text { Proteção dos consumidores; } \\
\text { Incitar a redução de custos. }\end{array}$ \\
\hline Desvantagens & $\begin{array}{l}\text { Tendência à má alocação de } \\
\text { recursos (efeito Averch-Johnson); } \\
\text { Multiplicação de reajustes; } \\
\text { Nenhuma incitação à redução de } \\
\text { custos. }\end{array}$ & $\begin{array}{l}\text { Necessidade de definição de um } \\
\text { padrão mínimo de qualidade; } \\
\text { Critério para a revisão do } \\
\text { parâmetro X (assimetria de } \\
\text { informação); } \\
\text { Se ambiente econômico incerto: } \\
\text { price cap é alto, ou prazo para a } \\
\text { revisão de X longo. }\end{array}$ \\
\hline
\end{tabular}

Quadro 1 - Características de políticas regulatórias (taxa de retorno e price cap). Fonte: adaptado de Pinto Júnior \& Silveira (1999)

A precificação de energia elétrica no modelo de price-cap, na presença de incerteza quanto à demanda futura, implica, que os preços nunca serão inferiores ao 
preço que seria determinado de forma competitiva, havendo um incentivo para o subinvestimento e racionamento na quantidade ofertada.

Em indústrias prestadoras de serviços isto se manifestaria com uma degradação da qualidade do serviço, razão pela qual essa forma de regulação de preço deve ser implementada na presença de padrões de qualidade do serviço, que sejam fiscalizados e estimulados (Vakhitova, 1998) pelo agente regulador.

O sistema de tarifação pelo método do "price cap" consiste nas fórmulas de reajuste referidas que devem ser aplicados periodicamente sobre uma "tarifa inicial". A definição da tarifa inicial pode ocorrer na legislação, em atos do poder regulador ou segundo um valor definido no contrato de concessão.

$\mathrm{Na}$ ISEB o processo de privatização das distribuidoras de energia elétrica na segunda metade da década de 1990 e a conseqüente assinatura dos respectivos contratos de concessão determinou a maioria das tarifas iniciais que servem de parâmetro para as tarifas atualmente aplicadas. As empresas que não foram privatizadas e que não assinaram novos contratos de concessão tiveram suas tarifas iniciais definidas em atos do ente regulador baseados nas tarifas já praticadas, com revisão de valores em alguns casos.

Entre 1995 e 1998, o programa brasileiro de privatização gerou US\$ 60 bilhões aos cofres da União e dos estados, além de transferir as dívidas das empresas estatais que foram assumidas pelo setor privado, em um valor superior a US\$8,6 bilhões (Salgado, 2003).

Apesar da dívidas assumidas pelos investidores privados serem relativamente altas, o atual nível de endividamento do setor elétrico do Brasil não é maior que o patamar verificado nos Estados Unidos. Comparando-se as maiores 29 empresas brasileiras e 26 norte-americanas, obteve-se que a relação da dívida total sobre o patrimônio líquido no Brasil é de cerca de $82 \%$, contra uma média de aproximadamente $200 \%$ nos EUA (ANEEL, 2002).

A privatização das empresas prestadoras do serviço de distribuição de energia elétrica dependeu da aprovação em 1995 da Lei de Concessões (Lei $n^{\circ}$ 8.987/95), que veio a ser complementada pela Lei $n^{\circ}$ 9.074/95, que renovou e prorrogou as concessões em vigor. Para auxiliar no processo de definição do novo modelo do setor 
elétrico a ser aplicado após a privatização das demais empresas o Governo Federal contratou em 1997 a empresa de consultoria Coopers \& Lybrand.

O novo modelo do setor elétrico proposto por essa empresa de consultoria passou a ser implementado em setembro de 1998 com a criação do Mercado Atacadista de Energia (MAE) e do Operador Nacional do Sistema (ONS), sendo fortemente inspirado pelo modelo implementado na Grã-Bretanha na primeira metade da década de 1990 de criação de concorrência nos setores em que fosse possível.

Os três pilares básicos do modelo são: a) a competição na geração e na comercialização de energia elétrica; $b$ ) a criação de instrumental regulatório para a defesa da concorrência nos segmentos competitivos (em particular com a desintegração vertical, a definição de tarifas de uso da rede não-discriminatórias e a garantia do livre acesso nos sistemas de transporte (transmissão e distribuição)); e $c$ ) o desenvolvimento de mecanismos de incentivos nos segmentos que permanecem como monopólios naturais (distribuição de energia para o mercado cativo e transmissão).

A ANEEL também definiu limites de concentração de mercado em níveis nacionais e regionais para as capacidades de distribuição e geração, separando-as, ainda. Foi definido também um cronograma que regulava a expansão do número de "consumidores livres" (Ferreira, 2000).

O antigo DNAEE, ente regulador da ISEB até a criação da ANEEL, participou ativamente da redação dos contratos de concessão assessorando o Poder Executivo no processo de privatização. Esses contratos eram descritos nos editais de venda, que por sua vez, além de conter metas de qualidade, traziam nas cláusulas tarifárias as tabelas para as tarifas iniciais que foram consideradas nas avaliações do valor econômico da empresa.

A privatização no setor elétrico foi mais complexa do que a privatização do setor de telecomunicações, dada a diversidade de controle das empresas do setor. $O$ Governo Federal era proprietário das mais importantes empresas de geração e transmissão, enquanto os governos estaduais possuíam a maioria das empresas de distribuição de energia elétrica, além de algumas empresas, tanto federais como estaduais, serem integradas possuindo capacidades relevantes em todas essas atividades (Ferreira, 2000). Em 1995 as empresas estaduais eram responsáveis pela 
geração de $38 \%$ da energia elétrica nacional, além da quase totalidade do mercado de distribuição.

Diferentemente do setor de telecomunicações, que dispunha de um novo modelo regulatório quando da privatização das empresas, a privatização da maioria das empresas elétricas ocorreu enquanto ainda eram discutidos os contornos do novo ambiente regulatório. Em 1997 nove empresas estaduais de distribuição foram privatizadas e mais cinco foram privatizadas em 1998. Assim, dezoito empresas já estavam privatizadas antes que dois atores centrais do novo modelo regulatório (MAE e ONS) estivessem legalmente estabelecidos.

Isso contribuiu para que o processo regulatório do setor elétrico fosse prejudicado, já que a definição de novas regras regulatórias dependiam da "concordância" dos novos controladores das empresas recém privatizadas, em função da cláusula do "equilíbrio econômico-financeiro" dos contratos de concessão e da própria Constituição Federal, que prevê que após a concessão não podem ser impostos novos ônus e encargos às concessionárias, sem a devida compensação.

A nova regulação do setor também teve dificuldades para garantir aos controladores privados de empresas de geração a justa remuneração, cujo cálculo era complexo tendo em vista que a geração de energia dependia de plantas com bases tecnológicas e estruturas de custos diversas. A definição do preço de energia passaria a considerar um mix da energia fornecida pelas antigas usinas hidrelétricas cujo Megawatt/hora era vendido entre US\$ 10 e US\$12, a energia das usinas hidrelétricas mais recentes ccom o Megawatt/hora vendido entre US\$32 e US\$34 e a energia das empresas termoelétricas cujo MWh era vendido entre US\$ 39 e US\$ 41.

O processo de outorga da concessão mediante licitação conjunta da empresa e da concessão quando da privatização foi fundamentado no critério de maior proposta de pagamento pela outorga da concessão e não de menor tarifa para prestação do serviço. Esse critério era previsto no Programa Nacional de Desestatização - PND, que determinava a utilização do critério do fluxo de caixa descontado e de fixação e reajuste das tarifas para arbitramento do preço mínimo.

Apesar dos reajustes tarifários na ISEB serem inferiores aos que foram verificados no setor de telecomunicações, igualmente privatizados, alguns estudos 
indicam que em termos absolutos as tarifas de energia elétrica seriam elevadas em comparação com as praticadas em outros países.

\begin{tabular}{|c|c|c|c|c|c|c|c|c|c|}
\hline Países & $\mathbf{1 9 8 9}$ & $\mathbf{1 9 9 0}$ & $\mathbf{1 9 9 1}$ & $\mathbf{1 9 9 2}$ & $\mathbf{1 9 9 3}$ & $\mathbf{1 9 9 4}$ & $\mathbf{1 9 9 5}$ & $\mathbf{1 9 9 6}$ & $\mathbf{1 9 9 7}$ \\
\hline Brasil & 100 & 152 & 136 & 147 & 152 & 177 & 189 & 240 & 240 \\
\hline EUA & 100 & 104 & 107 & 109 & 109 & 111 & 111 & 111 & 111 \\
\hline França & 100 & 106 & 104 & 108 & 108 & 108 & 108 & 109 & 109 \\
\hline Noruega & 100 & 107 & 111 & 118 & 123 & 118 & 120 & 125 & 125 \\
\hline R. Unido & 100 & 106 & 111 & 119 & 114 & 116 & 114 & 114 & 114 \\
\hline OECD & 100 & 105 & 109 & 114 & 115 & 117 & 120 & 118 & 118 \\
\hline
\end{tabular}

Quadro 2 - Evolução real das tarifas residenciais de eletricidade.

Fonte: adaptado de Abreu (1999)

O método do price cap, ou preço limite, tem como fundamento o reajuste anual da tarifa inicial através da aplicação de um índice de preços ao consumidor que, na maioria das distribuidoras de energia da ISEB é o IGPM da Fundação Getúlio Vargas. Além dos reajustes anuais que buscam evitar a corrosão inflacionária das tarifas de energia elétrica, periodicamente as tarifas praticadas pela distribuidoras são submetidas à revisão pelo agente regulador.

A revisão tarifária periódica constitui em um instrumento regulatório do novo regime econômico e financeiro implementado a partir de 1995 mediante o qual se assegura que os ganhos de eficiência empresarial se expressem em tarifas inferiores. $\mathrm{Na}$ revisão tarifária as tarifas são alteradas segundo uma metodologia que consiste em revisar as condições de desempenho da concessionária.

A tarifa do serviço de distribuição de energia elétrica é então reposicionada num novo patamar de "preço máximo" de forma a expressar os ganhos de eficiência obtidos e apropriados pela concessionária e ao longo dos anos que antecedem a primeira revisão tarifária contratual.

O prazo de revisão tarifária varia de quatro a sete anos, segundo o contrato de concessão de cada distribuidora, sendo a maioria realizada a cada cinco anos. Em cada revisão tarifária o agente regulador realiza uma ampla avaliação da performance da distribuidora buscando identificar os ganhos de produtividade obtidos pelas firmas com a incorporação de novas tecnologias e novas técnicas de gestão. 
O objetivo dessa revisão é garantir que parte dos ganhos de produtividade obtidos pela empresa sejam repassados aos consumidores através da definição de um percentual " $X$ " que será abatido do índice de preços aplicável nos próximos reajustes tarifários. Esse método tarifário faz com que anualmente as tarifas sejam reajustadas em níveis inferiores ao da inflação (Pires \& Piscinnini, 1999).

Nesse sistema as contas de energia são divididas em duas parcelas " $A$ " e "B", segundo os contratos de concessão. A Parcela "A", inclui os custos "não gerenciáveis" pelas distribuidoras, tais como, o valor da energia comprada, os encargos setoriais (contribuição para a ANEEL, tarifa de transmissão de energia, Conta de Consumo de Combustíveis Fósseis-CCC, Reserva Geral de Reversão-RGR) e os impostos que incidem sobre o consumo de energia.

A Parcela "B", que é a parte do faturamento da venda de energia ao consumidor final constitui a renda da empresa distribuidora e é a responsável por custear todas as despesas da empresa com pessoal, materiais, investimentos na expansão, na manutenção e na melhoria da qualidade do sistema elétrico, serviços de terceiros, melhoria da qualidade do sistema elétrico e lucro dos acionistas.

\begin{tabular}{|c|c|}
\hline \multicolumn{2}{|c|}{ Variação 1998-2002 } \\
\hline IGPM & $55 \%$ \\
\hline Tarifa & $89 \%$ \\
\hline Parcela A & $148 \%$ \\
\hline Parcela B & $2 \%$ \\
\hline
\end{tabular}

\begin{tabular}{|c|c|}
\hline \multicolumn{2}{|c|}{ Maiores Variações na Parcela A } \\
\hline Tributos & $100 \%$ \\
\hline Encargos & $200 \%$ \\
\hline Geração & $182 \%$ \\
\hline Transmissão & $117 \%$ \\
\hline
\end{tabular}

\begin{tabular}{|c|c|c|}
\hline Receita & $\begin{array}{c}\text { Parcela A } \\
\text { Custos não gerenciáveis } \\
\end{array}$ & $\begin{array}{c}\text { Parcela B } \\
\text { Custos Gerenciáveis }\end{array}$ \\
\hline Tarifa $\times$ Volume de energia & $\begin{array}{l}\text { Energia Comprada } \\
\quad \text { Transmissão } \\
\text { Encargos Setoriais }\end{array}$ & $\begin{array}{c}\text { Custos Operacionais } \\
\text { Depreciação } \\
\text { Remuneração do capital }\end{array}$ \\
\hline Regras de revisão & Repasse total dos custos & $\begin{array}{c}\text { Atualização monetária } \\
\text { via IGPM (anual) } \\
\text { Revisão tarifária a cada } 5 \text { anos } \\
\text { Fator X } \\
\end{array}$ \\
\hline Destino dos recursos & $\begin{array}{l}\text { Repasse para geradoras e } \\
\text { Governo }\end{array}$ & Receita das distribuidoras \\
\hline
\end{tabular}

Quadro 3 - Composição do preço final da energia elétrica.

Fonte: adaptado de Sambo (2003) 
A Parcela "A" da tarifa, é corrigida anualmente pela variação dos custos comprovados pela empresa e de conhecimento da ANEEL. A Parcela "B" é corrigida anualmente pelo IGPM e, a cada quatro anos, passa pelo processo de revisão tarifária. Nos últimos quatro anos, a receita real das distribuidoras (Parcela B), segundo campanha divulgada na imprensa nacional pela Associação Brasileira de Distribuidoras de Energia Elétrica-ABRADEE, foi afetada pelo não-repasse integral dos custos com a energia comprada e pela redução do consumo de energia.

Segundo enquanto a Parcela A subiu acima da inflação. Segundo esses dados o aumento dos gastos pelo consumidor final com o serviço de energia elétrica foi decorrente do aumento de encargos impostos pelo Governo Federal (148\% no período) e não do aumento de receita das empresas distribuidoras ( $2 \%$ no período).

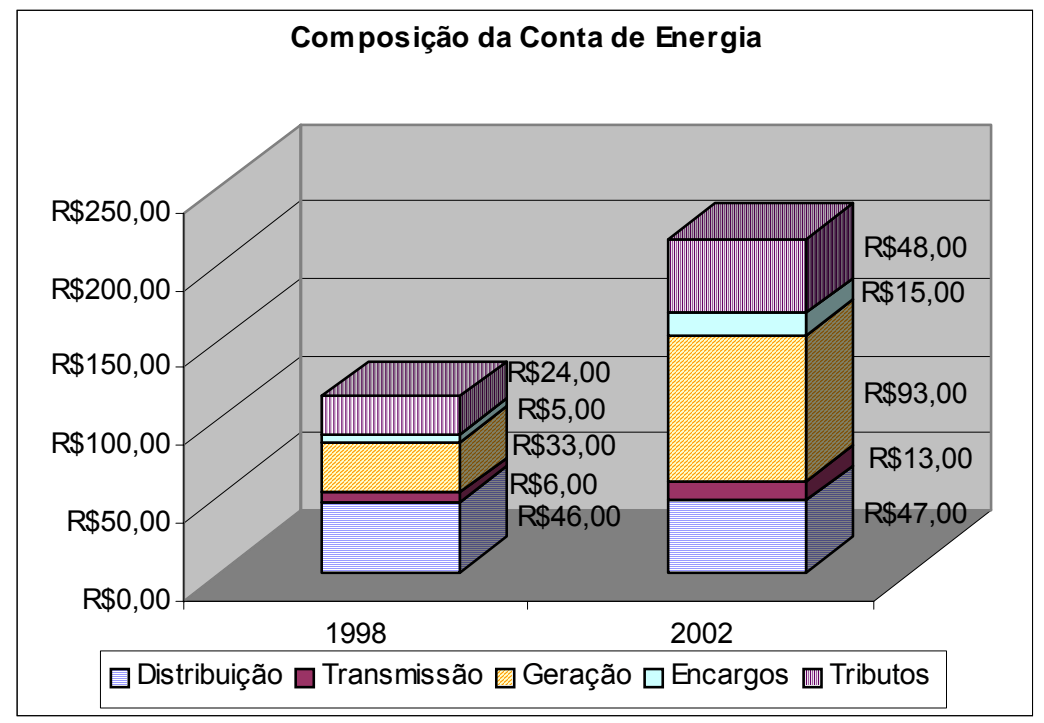

Figura 10 - Composição da Conta de Energia.

Fonte: adaptado de CPFL Energia (2003)

A maioria das empresas privatizadas adotou os seguintes métodos para aumentar a receita e diminuir os custos (Abreu, 1999):

a) dispensar grande parte dos funcionários das antigas estatais e optar por admitir outros, com salários menores;

b) a terceirização de diversos serviços que eram prestados por pessoal próprio; 
c) fiscalização da operação e manutenção das redes, tendo como finalidade a obtenção de ganho com as reduções das perdas no sistema de transmissão e distribuição; além de detectarem e eliminarem os pontos, nos quais existiam ligações clandestinas.

Durante o processo de revisão tarifária as distribuidoras de energia elétrica indicaram ao ente regulador uma série de custos que foram impostos à sua atividade e que não foram repassados às tarifas. Esses custos, no período de 1997 a 2000 , decorriam principalmente do não-repasse para as tarifas da variação integral dos preços da energia que as distribuidoras compravam das geradoras, principalmente de Itaipu, em função da variação cambial no período.

Em função do racionamento de 2001 as empresas distribuidoras enfrentaram uma redução de suas vendas por força de determinações de racionamento do Governo Federal e da incapacidade das empresas geradoras (em sua maioria sob controle do Governo Federal) de adimplir os contratos firmados de entrega de determinada quantidade de energia. As sanções pelo descumprimento de tais contratos (Anexo $\mathrm{V}$ dos contratos de concessão) implicariam em grandes penalidades às empresas geradoras, calculadas com base na variação do preço spot da energia no MAE que, em poucos meses de 2001, variaram de $\mathrm{R} \$ 4,50 / \mathrm{MWh}$ a $\mathrm{R} \$ 214,00 / \mathrm{Mwh}$ quando foram congelados pelo Governo Federal.

Essas multas seriam devidas às distribuidoras, em sua maioria privatizadas, em razão da incapacidade de entrega da energia contratada. A cobrança dessas multas não foi autorizada pelo Governo Federal, dado o risco de falência das empresas geradoras. A solução dessa controvérsia veio com a celebração do Acordo Geral do Setor Elétrico de 2001 entre todas as firmas da ISEB e a entidade reguladora (ANEEL) quando passou a vigorar a Conta de Variação de Valores de Itens da parcela A (CVA) e os aumentos de custos foram registrados para compensação no reajuste seguinte. O mesmo acordo criou o Ativo Regulatório, mecanismo no qual foram parcialmente compensadas as perdas nas vendas de energia durante o racionamento de energia em 2001, além de parte da variação cambial e seus reflexos sobre os custos das empresas distribuidoras.

Os custos de tal acordo foram repassados aos consumidores de energia elétrica através de reajustes tarifários, imposição de "encargos tarifários" que devem 
ser repassados ao Governo Federal e às estatais e aumento dos tributos incidentes sobre o consumo final.

\subsubsection{Regulação por comparação}

Além da regulação tarifária o ente regulador pode intervir na atividade das empresas que atuam sob o regime de monopólio através do estabelecimento de padrões de performance decorrentes da comparação dos resultados da empresa sob análise com o resultado de empresas que atuam em mercados similares ou até mesmo firmas "teóricas" obtidas da média do desempenho de todas as firmas ou de padrões fixados na legislação. O método de comparação, ou yardstick competition, de desempenho consiste em uma forma de reproduzir artificialmente um ambiente competitivo, quando, por motivos de organização industrial, a oferta deve, necessariamente, assumir a forma de um monopólio natural.

Por esse mecanismo, o regulador dispõe de um padrão de avaliação de desempenho das firmas, podendo-se comparar monopólios regionais em condições semelhantes. A remuneração de uma firma é definida comparando o seu desempenho com o de outras, tornando-a sensível aos custos e aos preços das demais firmas (Salgado, 2003).

O regulador deve utilizar mecanismos para estimular eficiência nos investimentos realizados pela empresa regulada, de forma que a base de remuneração reflita o nível de investimentos efetivamente necessários para a prestação do serviço regulado, com os níveis de qualidade exigidos.

A ANEEL estabeleceu como metodologia da revisão tarifária o conceito de "empresa de referência" para o levantamento do custo mínimo ideal de funcionamento das concessionárias, o que influenciou os parâmetros de reajuste tarifário.

\subsubsection{A experiência regulatória internacional}

A lei britânica determinou a desverticalização das atividades de geração (Salgado, 2003), transmissão e distribuição, criou a atividade de comercialização de 
energia e introduziu incentivos à eficiência nos segmentos de monopólio natural (transmissão e distribuição).

No Reino Unido os reguladores de utilities (gás, energia e água) determinam o valor inicial do investimento a ser remunerado com base no valor econômico de mercado da concessão, representado pela cotação média em bolsa de valores das ações negociadas de empresas recém privatizadas. No caso das companhias britânicas regionais (British Regional Electricity Companies - RECs), o regulador permitiu a incorporação de um acréscimo de $15 \%$ no valor do investimento em função da flutuação das ações no final do primeiro dia de pregão após a privatização.

Consistente com o método de financial capital maintanance, o regulador de energia elétrica tem permitido que a base de remuneração seja indexada pelo índice de preços ao consumidor. A depreciação de ativos anteriores à privatização, nos segmentos de transmissão e distribuição de energia elétrica - com exceção da Northern Ireland Electricity - é calculada pelo método linear considerando os ativos como um único item, cuja vida útil estimada pela média dos itens que formavam a base de remuneração naquele momento.

Após uma década de privatização na indústria elétrica britânica, ainda não foi possível promover-se a concorrência de fato em setores potencialmente competitivos, como o de geração. Criou-se, nesse segmento, um duopólio, que tem recorrentemente sido objeto de processos, por práticas de cartelização e abuso de posição dominante. Por outro lado, o mercado atacadista, onde se esperava operar a maior parte das transações de energia em bases competitivas, responde hoje por menos de $10 \%$ da energia comercializada. A reestruturação britânica mostra a importância da regulação da concorrência para o controle do processo de concentração e de práticas anticompetitivas (Salgado, 2003), diante dos riscos de manipulação de preços, da assimetria de informações e do comportamento oportunista na declaração de capacidade e de custos.

No sistema regulatório implementado na Espanha o cálculo do "valor de referência" que serve de base para a remuneração das concessionárias inclui os custos de distribuição do ano anterior (investimentos, custo da energia contratada, gastos na operação e manutenção de máquinas/equipamentos e custos de gestão comercial), aplicando-se a variação do índice de preços ao consumidor e uma projeção para o incremento do consumo de energia. 
Nesse sistema não se considera nenhum critério de depreciação para os ativos do período anterior a 1998, uma vez que estes são medidos pelo valor de referência, o qual é definido pelo governo e informado às companhias anualmente. Quanto aos investimentos realizados após 1998, o cálculo da depreciação considera uma vida útil de 40 anos. Após este período, o Governo espanhol oferece um incentivo financeiro para a manutenção destes ativos, de acordo com a perspectiva de vida útil remanescente estimada. Novos investimentos em ativos devem ser autorizados pelo Governo, que calcula o valor global de investimentos anualmente, em valor compatível com o custo de reposição (Salgado, 2003).

Nos Estados Unidos da América a maioria dos Estados utiliza os conceitos da Federal Energy Regulatory Commission (FERC) a respeito de ativos, obrigações, renda e gastos para a definição da base de remuneração. Em termos gerais, todos os ativos (equipamentos de geração, transmissão e distribuição, serviços a clientes e ativos de suporte administrativo) com valor superior a US\$500,00, vinculados à prestação de serviços a clientes e que estejam em operação são incluídos na base de remuneração. Os ativos são avaliados em valor compatível ao custo de reposição. A descrição completa dos ativos e dos custos que podem ser considerados na base de ativos encontra-se no Electric Plant Accounts.

Os dois princípios básicos estabelecidos pelo Energy Policy Act norteamericano são a garantia do livre acesso aos sistemas de transmissão e a constituição de grandes mercados atacadistas. Para tanto, a FERC estimulou a constituição de operadores independentes do sistema (ISO's), para gerenciarem o despacho de energia (Salgado, 2003). Adicionalmente, incentivou-se a criação de Bolsas de Energia (Power Exchange), mercados nos quais se realizariam transações spot entre geradores e consumidores livres.

\subsection{Discriminação de preços e estrutura tarifária na ISEB}

A política tarifária praticada na ISEB á caracterizada por uma forte segmentação tarifária em função do tipo de atividade exercida pelo consumidor e pelo seu perfil de consumo, que são indicadores de sua demanda pela energia elétrica. Essa diferenciação tarifária possui base legal e está incorporada às práticas tarifárias da ISEB, desde a edição do Código de Águas na década de 1930. 
A segmentação tarifária no mercado de distribuição da ISEB consiste na cobrança de diferentes tarifas a diferentes classes de consumidores, em função da atividade exercida, as condições de fornecimento e o montante de consumo da atividade. A legislação autoriza a cada firma distribuidora a diferenciação tarifária, com a cobrança de 50 preços diferentes para a mesma unidade de energia, em função da relevância social das atividades (Vide Anexo). 


\section{METODOLOGIA}

O presente estudo tem natureza essencialmente analítica e descritiva, não tendo sido estabelecido nenhum modelo empírico de teste dos dados apresentados. Também não pretendeu-se a coleta de dados ou de séries temporais para análise da política de Tarifa Social implementada na Indústria do Setor Elétrico Brasileira - ISEB, limitando-se a uma descrição da evolução histórica dessa política tarifária e de suas características, em comparação com os modelos teóricos de discriminação de preços da Teoria do Monopólio.

A principal contribuição do presente trabalho é o esforço de descrição da evolução da Tarifa Social de energia elétrica brasileira, até então inédita. Para tanto foi necessária a descrição das principais características da ISEB, quanto à forma de operação das firmas que a integram, as características do produto e sua comercialização, as estruturas de poder que controlam as firmas e a regulação estatal que condiciona o comportamento das firmas, especialmente quanto à tarifa ou preço.

Procedeu-se a uma revisão da literatura de teoria econômica sobre a caracterização do monopólio, especificamente do monopólio natural, do comportamento monopolista e a possibilidade de discriminação de preços como estratégia de maximização de lucros. Discutiu-se também a adequação da caracterização da ISEB e das firmas que a integram de acordo com o modelo teórico da Teoria do Monopólio.

A descrição sistemática da evolução da Tarifa Social, das políticas tarifárias implementadas na ISEB e dos modelos implementados internacionalmente na regulação da indústria elétrica, em especial da política de Tarifa Social será analisada em termos qualitativos quanto à sua aderência aos modelos teóricos de discriminação de preços e os resultados ao consumidor final que foram obtidos nos últimos anos. 


\section{RESULTADOS}

O objeto principal do presente estudo consiste na apresentação das diferentes políticas tarifárias aplicadas à classe residencial no período 1985-2002, ou seja, quanto ao critérios para a concessão de descontos, o percentual de descontos e a forma de cálculo do desconto concedido. A descrição da política tarifária praticada em relação aos consumidores residenciais no período imediatamente interior ao abrangido no presente estudo (1974-1985) teve como objetivo fornecer um referencial de avaliação às políticas implementadas a partir de 1985. Nessa análise são descritos em detalhe os critérios utilizados para a discriminação dos consumidores residenciais de "baixa renda" e os consumidores residenciais "normais", que não receberiam os descontos sobre o total consumido.

A análise empreendida buscou identificar a adequação na concessão dos descontos da Tarifa Social não somente em relação aos objetivos declarados pelo Governo Federal de ampliação do acesso à energia elétrica à população de baixa renda (Bitu, 1985), mas especialmente em relação às conjunturas da ISEB ao longo do período considerado em comparação com os modelos descritos na literatura.

\subsection{Evolução da Tarifa Social na ISEB}

Foram criados no Brasil, durante o período em que o fornecimento de serviços públicos eram predominantemente prestados por empresas estatais, vários programas de atendimento a parcelas da população com menores níveis de renda (França, 1999). Enquanto coube ao Estado financiar os investimentos em setores de infra-estrutura, como o de energia elétrica, foi possível à implantação de vários programas sociais, consistentes em tarifas com descontos a determinadas classes de consumidores, através de critérios nem sempre objetivos (Ramalho, 2002). 
Essa prática não era restrita às concessionárias de distribuição de energia mas também concessionárias estatais de fornecimento de água, tratamento de esgotos, telefonia, transportes. Tais políticas eram freqüentemente utilizadas como ferramentas de redistribuição de renda no atendimento à população mais carente. Tais programas não consistiam apenas em programas de descontos, mas também de universalização do acesso, cabendo às empresas estatais estender suas redes de distribuição desses serviços, de forma permitir o acesso físico da maior parcela da população.

Apesar do relativo sucesso das empresas distribuidoras de energia elétrica na extensão de seus sistemas nos últimos 30 anos, permitindo o acesso físico de um crescente número de consumidores à rede de distribuição, a exclusão elétrica ainda é um problema relevante em algumas regiões do país. A exclusão elétrica é um fenômeno essencialmente regional e rural, sendo que $63,9 \%$ dos domicílios sem acesso à energia elétrica situam-se na região Nordeste e $81,6 \%$ dos domicílios sem acesso à energia elétrica estão situados na zona rural. Mais de $60 \%$ dos domicílios sem acesso à energia elétrica apresentam renda per capita inferior a meio salário mínimo (Campelo et. al., 2003), sendo que a maioria destes domicílios também não têm acesso aos serviços de distribuição de água, rede de esgotos ou coleta de lixo. A exclusão elétrica, em seu aspecto de política social, não pode ser diminuída apenas com a criação de programas de extensão física das redes devendo ser complementada por uma política tarifária adequada que permita que esses consumidores, em sua maioria de baixa renda familiar, possam pagar pela energia que é ofertada no seu local de residência.

\subsubsection{Tarifa Social: período 1974-1985}

A Lei no 5.899 , de 5 de julho de 1973, atribuiu à Eletrobrás a competência para promover, através de suas empresas de âmbito regional, a construção e a operação de sistemas de transmissão em alta e extra-alta tensões, visando à integração, à operação de sistemas e ao transporte de energia elétrica de Itaipu.

Em dezembro de 1973, instituiu-se a política de "equalização tarifária" que impunha tarifas idênticas a todas as regiões do País. Considerada a classificação do consumidor em uma das subclasses tarifárias, o preço de cada unidade de energia seria igual, independentemente da distribuidora monopolista local, de sua estrutura de 
custos ou das características do seu mercado. A definição da tarifa única para cada classe de consumo fez com que empresas distribuidoras fossem divididas em dois grupos - deficitárias e superavitárias - em função de sua estrutura de custos, amplamente diferenciada geograficamente e o nível tarifário médio definido para todo o País.

Mesmo com a quadruplicação do preço do petróleo em 1973, as tarifas de energia elétrica foram reajustadas em níveis inferiores ao da inflação (II PND) o que levou a uma diminuição da receita das firmas da ISEB, como forma de obter-se resultados macroecômicos de controle da inflação. Com a edição do Decreto 79.706/77 a competência para definição das tarifas de energia elétrica deixou de pertencer aos agentes do setor elétrico (MME, DNAEE, empresas estatais) passando ao Ministério da Fazenda, reforçando a tendência de gestão do setor elétrico como instrumento de política macroeconômica. Essa política tarifária de reajustes em níveis inferiores à inflação fez com que a tarifa média em 1979 correspondesse a apenas $76 \%$ do valor da tarifa média de 1975 (Borestein \& Camargo, 1997). A política de barateamento da eletricidade a partir de 1973, buscava uma redução da dependência energética nacional, especialmente dos derivados de petróleo, inclusive com a concessão ao setor industrial, via tarifa, de estímulos para substituição de equipamentos movidos por derivados de petróleo, por outros que utilizassem energia elétrica.

A equalização financeira do faturamento das distribuidoras era feita através da conta gerida pela Eletrobrás denominada de "Reserva Global de Garantia - RGG" (Lei n. 5.655/1971), que fazia a transferência de recursos entre as concessionárias superavitárias e deficitárias. Como conseqüências dessa política tarifária foram feitos investimentos energéticos em regiões rurais, em regiões de pouco potencial de retorno econômico devido à baixa renda da população atendida, em sistemas isolados, além de investimentos em tecnologias de elevado custo como as usinas nucleares de Angra dos Reis, com a cobrança de tarifas inferiores aos custos de fornecimento nos mercados atendidos por esses sistemas, conforme Barros (2000). Por outro lado, essa política desestimulava a busca de eficiência pelas empresas superavitárias, que operavam em mercados mais rentáveis ou possuíam uma estrutura de custo mais competitiva, pois não poderiam se apropriar do lucro de sua operação, que seria destinado a subsidiar as empresas deficitárias. 
Em 1979, com a compra pelo governo brasileiro das ações da Light (multinacional Brascan Limited), todas as concessionárias do setor de energia elétrica passaram a ser constituídas totalmente por capital nacional (Abreu, 1999).A partir de 1979, o endividamento externo do setor elétrico, contraído durante a década de 1970, foi agravado pelo aumento das taxas de juros internacionais e pela manipulação das tarifas que foram utilizadas como um mecanismo de controle da inflação especialmente no período 1982 a 1993. A utilização das empresas da ISEB, pelo Governo Federal, como instrumento de implantação de políticas de desenvolvimento industrial no país e agente de combate à inflação, levou a ISEB à estagnação por falta de recursos.

Essa política fez com que a dívida do setor elétrico chegasse a US\$24 bilhões em 1986, dos quais cerca de $80 \%$ em moeda estrangeira, inclusive gerando um grande nível de inadimplemento intra-setorial (Borestein \& Camargo, 1997). As concessionárias estaduais passaram a não recolher os valores devidos à Eletrobrás e a suas insumidoras (geradoras e transmissoras), alegando dificuldades financeiras de correntes da contenção tarifária e da inexistência de recursos para a expansão do sistema (Borestein \& Camargo, 1997).

\subsubsection{Tarifa Social: período 1985-1993}

A ISEB apresentou na década de 1970 uma forte expansão, tanto em capacidade instalada (geração), como em novos usuários conectados às redes de distribuição além de níveis de consumo mais elevados por unidade consumidora. Nesse período a participação da classe residencial se expandiu, com o número de usuários crescendo à taxa anual de $9,6 \%$ e o consumo em 13,3\% (contra um crescimento populacional de 1,7\%) ao ano, apesar de sua diminuição relativa no faturamento do setor devido à expansão do setor industrial (CESP, 1981).

A evolução da capacidade de geração teve como causa as medidas do II PND (1975-1979), quando a Eletrobrás elaborou o Plano 90, visando ao atendimento do mercado de energia elétrica até 1990, com uma projeção de crescimento do consumo em torno de $12 \%$ ao ano no período 1975-1980, e de 10\%, entre 1980 e 1990 (Dias, 1996). 
Em meados da década de oitenta, as empresas estatais começaram a ter problemas em manter a qualidade e a expansão do sistema, principalmente por dificuldades financeiras e administrativas, como também pela estagnação da demanda, em conseqüência da prolongada recessão e do otimismo das previsões do II PND quanto à expansão do mercado. Essas dificuldades se prorrogaram até o início da década de 1990, quando o sistema começou a apresentar enormes falhas e atingir o consumidor final de forma direta. $O$ programa de obras de geração foi praticamente paralisado e iniciou-se uma reorganização institucional do setor, com o objetivo de reduzir a presença do Estado na economia e no setor elétrico, o que levaria na mesma década à privatização das firmas da ISEB (Abreu, 1999).

A trajetória de expansão do setor elétrico verificada nos anos 1970 foi refreada pela recessão do início da década de 1980, através da redução do consumo de energia e da restrição para obtenção de novos financiamentos para ampliação da capacidade de geração, transmissão e distribuição. Em 1981, embora o mercado industrial tenha crescido à taxa negativa de $0,8 \%$, a capacidade instalada continuou sendo ampliada, com a conclusão de projetos em andamento. Esse descompasso que se manteve por algum tempo, gerou uma capacidade ociosa do sistema interligado, levando o setor a implantar, a partir de 1982 tarifas subsidiadas destinadas a substituição de derivados do petróleo por energia elétrica (Dias, 1996). A implementação das tarifas subsidiadas acabou por aumentar o consumo de energia elétrica, reduzindo a capacidade ociosa do sistema e justificando a manutenção de um patamar mínimo de investimento no setor elétrico.

As iniciativas do MME de implementação da Tarifa Social em 1985 estão inseridas, portanto, num contexto institucional em que se verifica:

a) excesso de capacidade de geração de energia elétrica, tornando racional a indução da expansão de seu consumo;

b) necessidade de expansão da base de usuários em um cenário de ausência de capacidade de investimento e alto endividamento do Setor Elétrico.

Em 1985, ISEB organizou um conjunto de medidas a serem propostas ao governo para a superação dessa crise dando origem ao Plano de Recuperação do Setor de Energia Elétrica (PRS), que se caracterizava pela proposta de alteração da estrutura de receitas e despesas do setor, bem como das condições de financiamento 
da expansão do sistema. Dentre as iniciativas de reforma da ISEB o MME propôs a implementação de políticas no escopo da Tarifa Social de barateamento do fornecimento da energia às famílias de baixa renda, especificamente com alterações quanto às situação de desequilíbrio constatadas quanto:

“- a existência de aproximadamente 1.600 .000 potenciais consumidores sob as redes de energia elétrica, ou próximos a elas, sem condições de auferirem em seus benefícios, por absoluta falta de recursos para os ramais de ligações, medidores e instalações internas;

- a incidência integral do Imposto Único sobre Energia Elétrica IUEE a partir do $31^{\circ} \mathrm{kWh}$ de consumo, criando uma descontinuidade no valor da conta quando consumo ultrapassa $30 \mathrm{kWh}$;

-a cobrança em alguns casos, da Taxa de lluminação Pública sobre as contas relativas a baixo consumo, às vezes, mais do que dobrando o valor da conta;

-a falta de comunicação efetiva entre concessionária e consumidor;

-a cobrança do acréscimo moratório, de 10\%, após o vencimento;

-no caso especial das habitações multifamiliares (cortiços) e multiresidenciais a distorção que leva a aplicação da tarifa de forma agregada em uma única conta, não permitindo o benefício dos descontos para os primeiros kWh consumidos em cada unidade familiar." (Bitu, 1985, p.6)

A Tarifa Social deveria representar, segundo essa iniciativa do MME, a partir de 1985, um aperfeiçoamento da política tarifária já praticada, desde meados da década de 1970, redefinindo-se os blocos de consumo e respectivos descontos (ampliação do desconto concedido nos primeiros $30 \mathrm{kWh}$ para os primeiros $50 \mathrm{kWh}$ ), eliminando-se a incidência do Imposto Único sobre Energia Elétrica - IUEE e diminuindo-se a multa de mora de $10 \%$ para $2 \%$, entre outras alternativas consideradas.

A implementação do Plano Cruzado em 1986 e os desequilíbrios macroeconômicos ocorridos nos anos seguintes ao estudo pioneiro do MME podem ser apontados como causas para que a implementação da Tarifa Social fosse adiada. Nova tentativa, igualmente inócua, ocorreu em 1987 com o programa proposto pela Eletrobrás denominado Revisão Institucional do Setor - REVISE (Borestein \& Camargo, 1997). A retomada de estudos para implementação de uma política tarifária 
de concessão de descontos às famílias de baixa renda ocorreu somente em meados da década de 1990 (Abreu, 1999), quando foi criada a Subclasse Residencial Baixa Renda.

\subsubsection{Tarifa Social: Período 1993-1996}

Apesar das conclusões do MME pela implementação da Tarifa Social na ISEB, a política tarifária de energia elétrica não foi alterada até 1993, quando a Lei 8.631, de 05 de março de 1993, procedeu a uma ampla reformulação do setor elétrico. As mudanças introduzidas na legislação buscavam permitir o saneamento financeiro do setor elétrico, cuja capacidade de investimento estava esgotada devido ao seu alto endividamento e o baixo valor das tarifas.

\begin{tabular}{|c|r|r|r|}
\hline Tarifa média por setor de consumo US\$/MWI Residencial & \multicolumn{1}{l|}{ Comercial } & \multicolumn{1}{l|}{ Industrial } \\
\hline $\mathbf{1 9 8 1}$ & 56,97 & 71,91 & 35,95 \\
\hline $\mathbf{1 9 8 2}$ & 53,63 & 69,46 & 33,82 \\
\hline $\mathbf{1 9 8 3}$ & 37,35 & 47,68 & 23,17 \\
\hline $\mathbf{1 9 8 4}$ & 34,09 & 43,44 & 23,18 \\
\hline $\mathbf{1 9 8 5}$ & 30,64 & 43,55 & 23,52 \\
\hline $\mathbf{1 9 8 6}$ & $\mathbf{2 9 , 3 0}$ & 46,14 & 24,68 \\
\hline $\mathbf{1 9 8 7}$ & 40,01 & 65,24 & 32,32 \\
\hline $\mathbf{1 9 8 8}$ & 43,30 & 75,16 & 36,35 \\
\hline $\mathbf{1 9 8 9}$ & 43,53 & 68,38 & 32,97 \\
\hline $\mathbf{1 9 9 0}$ & 66,02 & 84,12 & 43,49 \\
\hline $\mathbf{1 9 9 1}$ & 58,38 & 64,77 & 33,82 \\
\hline $\mathbf{1 9 9 2}$ & 64,03 & 71,72 & 38,65 \\
\hline
\end{tabular}

Quadro 4 - Tarifa Média por Setor de Consumo entre 1981 e 1992.

Fonte: adaptado de Abreu (1999)

Tais medidas compreendiam em síntese (Abreu, 1999):

a) o abandono da política de equalização tarifária;

b) a extinção da remuneração garantida (RENCOR- Reserva Nacional de Compensação de Remuneração);

c) liquidação dos saldos da Conta de Recursos a Compensar (CRC); 
d) a obrigatoriedade de adoção de "contratos de suprimento" entre as empresas de geração e distribuição de energia elétrica, gerenciados pelo GCOI da Eletrobrás S/A;

e) a reativação da Reserva Global de Reversão (RGR) como um fundo destinado compulsoriamente ao financiamento da expansão e melhoria dos serviços públicos de energia elétrica e aos programas de conservação de energia elétrica e de eletrificação;

f) adequação no rateio da Conta Nacional de Combustíveis (CCC).

Além de tais medidas, ainda em 1993 foi permitida a formação de consórcios entre concessionários e autoprodutores para a exploração de aproveitamentos hidrelétricos $^{1}$, o livre acesso à malha federal de transmissão e incentivada a competição nos segmentos de geração de energia elétrica².

A partir da Lei 8631 de 1993 as tarifas de distribuição de energia elétrica aos usuários finais passaram a sofrer reajustes periódicos, através da aprovação pelo DNAEE de planilhas enviadas por cada concessionária distribuidora. Esses reajustes eram autorizados periodicamente com o objetivo de garantir a cobertura do custo de serviço de cada concessionário, segundo suas características específicas, conforme definido pelo Decreto 774, de 18 de março de 1993, que regulamentou a Lei 8631.

Com a nova legislação, os saldos dos fundos setoriais foram transformados em títulos de securitização ("Elets") que puderam ser vendidos no mercado ou mesmo utilizados como "moedas podres" no processo de privatização. Assim, a Lei 8.631 representou o saneamento do setor elétrico e a redução do seu endividamento, que chegou, em 1995, a 14,43\% (Borestein \& Camargo, 1997).

O abandono da política de equalização tarifária não alterou a forma de tarifação do consumidor residencial. Apesar das tarifas estarem sendo fixadas em níveis superiores aos anteriores, iniciando um processo de recuperação das desvalorizações verificadas nos anos anteriores, os percentuais de descontos concedidos de acordo com o programa de Tarifa Social foram mantidos os mesmos, porém incidindo sobre tarifas sistematicamente mais elevadas.

\footnotetext{
${ }^{1}$ Decreto $n^{\circ} 915$ - Setembro de 1993

${ }^{2}$ Decreto n 1009 - Dezembro de 1993 e Portaria n. ${ }^{\circ} 337$ Abril de 1994.
} 
Os descontos referentes à Tarifa Social continuaram sendo concedidos a todos os consumidores residenciais, tendo como único critério o nível de consumo. A utilização desse único critério tinha como fundamento a suposta correlação entre consumo de energia elétrica e renda do consumidor.

A principal vantagem na utilização desse critério consistia no baixo custo de fiscalização envolvido na discriminação dos consumidores de baixa renda e o acompanhamento da política de concessão de descontos ao longo do tempo.

A aplicação indistinta desses descontos escalonados a todos os clientes residenciais representava uma importante distorção remanescente para o saneamento do Setor Elétrico, iniciado em 1993 (Prado Júnior, 1998) na medida em que reduzia a receita das firmas distribuidoras.

Em 1995 iniciou-se uma ampla reestruturação do setor elétrico, com a promulgação da Lei n.8.987 de fevereiro de 1995, que regulamentou as concessões desse serviço público, definindo normas que permitiriam a privatização. Nesse mesmo ano a Eletrobrás S/A foi incluída no Programa Nacional de Desestatização e foi autorizada a geração de energia elétrica através de produtores independentes.

Ao final de 1995, após 18 meses sem reajustes tarifários, período praticamente coincidente com a vigência do Plano Real, o DNAEE, reajustou linearmente em 20,5\% as tarifas de energia elétrica, contra uma inflação acumulada de 33,3\% (IGPM-FGV).

A classe residencial teve, no entanto, um tratamento diferenciado, pois o reajuste tarifário aplicado foi de apenas 3\% em algumas concessionárias e nulo nas demais (DNAEE- Portaria 437, de 06 de novembro de 1995), conforme Sauer (2002).

\begin{tabular}{|l|c|c|c|}
\hline Empresas & Alta tensão & Residencial & Rural \\
\hline CELESC & 13,5 & 0 & 13,5 \\
\hline CEMIG & 11,8 & 0 & 11,8 \\
\hline CERJ & 9,8 & 0 & 9,8 \\
\hline CESP & 20,5 & 3 & 20,5 \\
\hline COELBA & 19,5 & 0 & 19,5 \\
\hline COPEL & 12 & 0 & 12 \\
\hline CPFL & 11,1 & 3 & 11,1 \\
\hline ELETROPAULO & 12,3 & 3 & 12,3 \\
\hline ESCELSA & 6 & 0 & 6 \\
\hline LIGHT & 8 & 0 & 8 \\
\hline
\end{tabular}

Quadro 5 - Reajustes das tarifas de energia elétrica em novembro de 1995.

Fonte: adaptado de Abreu (1999) 
No aumento geral de tarifas ocorrido em novembro de 1995 a tarifa do setor residencial não teve aumentos significativos, mas por mudanças de enquadramento e redução da progressividade nos descontos das tarifas, a classe de consumidores residenciais arcou com aumentos substanciais nas contas de energia elétrica (Sauer, 2002), devido, principalmente, à diminuição do universo de beneficiados com os descontos escalonados da Tarifa Social pois passaram a pagar a tarifa de forma integral.

Para a implementação da nova Tarifa Social criou-se a "Subclasse Residencial de Baixa Renda" na Classe Residencial, a qual continuaria a receber descontos referentes ao consumo, porém com duas importantes distinções, conforme Quadro 6: a) o desconto deixaria de incidir "em cascata" sobre o consumo total e b) os percentuais de desconto de cada faixa de consumo foram reduzidos.

\begin{tabular}{|c|c|c|}
\cline { 2 - 3 } \multicolumn{1}{c|}{} & \multicolumn{2}{c|}{ DESCONTOS } \\
\hline $\begin{array}{c}\text { FAIXA DE CONSUMO } \\
\text { (kW/h mensais) }\end{array}$ & $\begin{array}{c}\text { ATÉ 1995 } \\
\text { Cl Cascata }\end{array}$ & $\begin{array}{c}\text { APÓS 1995 } \\
\text { S/Cascata }\end{array}$ \\
\hline $\mathbf{0 - 3 0}$ & 83 & 65 \\
\hline $\mathbf{3 1 - 1 0 0}$ & 55 & 40 \\
\hline $\mathbf{1 0 1 - 2 0 0}$ & 24 & 10 \\
\hline Maior que 200 & 0 & 0 \\
\hline
\end{tabular}

Quadro 6 - Descontos da Subclasse Residencial Baixa Renda - (1995).

Fonte: elaborado por Sauer (2002)

Segundo Sauer (2002), o impacto da mudança de sistemática foi desigual para os diferentes extratos de consumo afetando mais aqueles que consumiam até $30 \mathrm{kWh}$ e aqueles cujo consumo situava-se imediatamente acima do novo limite superior de consumo, pela perda total dos descontos, conforme Quadro 7, que foram definidos em: 


\begin{tabular}{|l|c|c|c|}
\hline \multicolumn{1}{|c|}{ Empresas } & $\begin{array}{c}\text { Limite de consumo } \\
\text { mensal com } \\
\text { desconto }\end{array}$ & $\begin{array}{c}\text { Aumento médio da } \\
\text { conta para consumo } \\
\text { logo abaixo do limite } \\
\text { de consumo mensal }\end{array}$ & $\begin{array}{c}\text { Aumento médio da conta } \\
\text { para consumo logo } \\
\text { acima do limite de } \\
\text { consumo mensal }\end{array}$ \\
\hline CELESC & 160 & $28,2 \%$ & $93,8 \%$ \\
\hline CEMIG & 180 & $26,6 \%$ & $84,0 \%$ \\
\hline CERJ & 140 & $30,6 \%$ & $108,0 \%$ \\
\hline CESP & 220 & $25,2 \%$ & $70,3 \%$ \\
\hline COELBA & 140 & $30,6 \%$ & $108,0 \%$ \\
\hline CPFL & 220 & $25,2 \%$ & $70,3 \%$ \\
\hline ELETROPAULO & 220 & $25,2 \%$ & $70,3 \%$ \\
\hline ESCELSA & 180 & $26,6 \%$ & $84,0 \%$ \\
\hline LIGHT & 200 & $25,4 \%$ & $76,8 \%$ \\
\hline
\end{tabular}

Quadro 7 - Efeitos da mudança dos critérios da tarifa social em 1995.

Fonte: elaborado por Sauer (2002)

O limite de consumo mensal foi definido segundo os perfis de consumo médio mensal em cada região do país, sendo menor na região nordeste e maior na região Sudeste.

Esse critério define um limite máximo de consumo mensal que sendo ultrapassado exclui a concessão de descontos da Tarifa Social, mesmo que a família preencha os demais requisitos. Conforme Figura 11 esses limites são adequados para a inclusão de aproximadamente 70 \% dos consumidores.

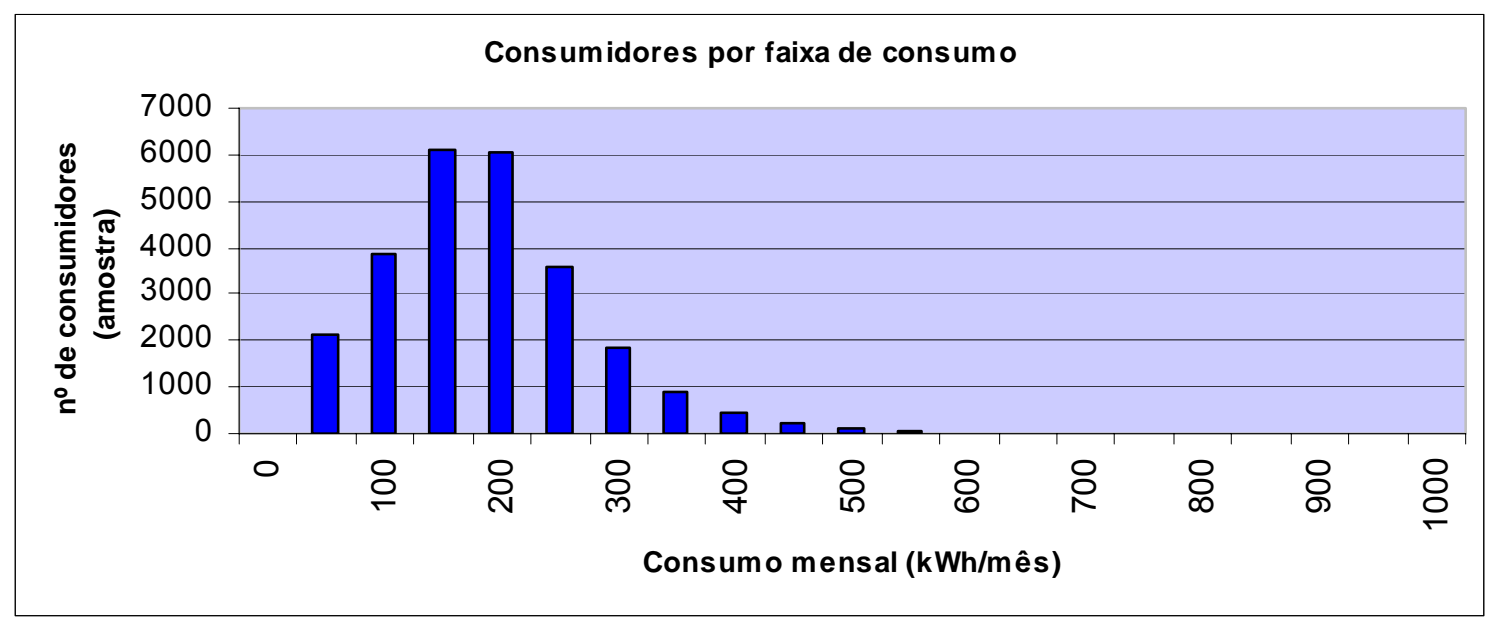

Figura 11 - Consumidores por faixa de consumo mensal (kWh/mês).

Fonte: elaborado a partir de Sauer et. al.(2000) 
Embora a Portaria 437/95 do DNAEE tenha criado a "Subclasse Residencial de Baixa Renda" não foram definidos os critérios que permitissem a diferenciação dos consumidores de "baixa renda" dos demais consumidores residenciais, para fins de concessão dos descontos. O estabelecimento dos critérios de classificação de tais consumidores foi delegado a cada concessionário, de acordo com o perfil dos consumidores de sua área de concessão (França, 1999).

Historicamente, a classe residencial tinha uma estrutura tarifária que concedia descontos para as primeiras faixas de consumo, independente do consumo total de energia elétrica. Mesmo um cliente residencial com um elevado consumo de $400 \mathrm{kWh} / \mathrm{mês}$, continuava a ter direito a desconto para as primeiras faixas de consumo.

Após a edição da Portaria 437/95, os descontos sobre as primeiras faixas de consumo foram limitados às unidades consumidoras classificadas na subclasse Residencial Baixa Renda (Campelo et. al., 2003).

\begin{tabular}{|l|c|c|c|c|c|}
\hline \multicolumn{7}{|c|}{ Percentual de desconto } \\
\hline $\begin{array}{c}\text { Faixas de } \\
\text { Consumo } \\
\text { (kWh/mês) }\end{array}$ & $\begin{array}{c}\text { a partir de } \\
\mathbf{1 4 / 0 1 / 8 9}\end{array}$ & $\begin{array}{c}\text { a partir de } \\
\mathbf{0 8 / 1 1 / 9 0}\end{array}$ & $\begin{array}{c}\text { a partir de } \\
\mathbf{0 1 / 0 2 / 9 1}\end{array}$ & $\begin{array}{c}\text { a partir de } \\
\mathbf{0 4 / 0 2 / 9 3}\end{array}$ & $\begin{array}{c}\text { a partir de } \\
\mathbf{0 5 / 1 1 / 9 5}\end{array}$ \\
\hline $\mathbf{0}$ a 30 & $89 \%$ & $70 \%$ & $60 \%$ & $81 \%$ & $65 \%$ \\
\hline $\mathbf{3 1}$ a 100 & $72 \%$ & $52 \%$ & $40 \%$ & $55 \%$ & $40 \%$ \\
\hline $\mathbf{1 0 1}$ a $\mathbf{2 0 0}$ & $65 \%$ & $45 \%$ & $35 \%$ & $24 \%$ & $10 \%$ \\
\hline $\mathbf{2 0 1}$ a 300 & $17 \%$ & $0 \%$ & $0 \%$ & $0 \%$ & $0 \%$ \\
\hline Acima de 300 & $0 \%$ & $0 \%$ & $0 \%$ & $0 \%$ & $0 \%$ \\
\hline
\end{tabular}

Quadro 8 - Evolução das taxas de desconto por faixa de consumo - Tarifa Social. Fonte: elaborado por França (1999)

O prazo de 90 dias para que os concessionários de distribuição apresentassem seus programas de "baixa renda" não foi cumprido pelas concessionárias e somente em abril de 1996 foram publicadas as primeiras Portarias de caracterização de unidades consumidoras enquadráveis na nova subclasse, enquanto que a conclusão do processo ocorreu em meados de 1997, quando muitas concessionárias já haviam sido privatizadas. 


\subsubsection{Tarifa Social: período 1996-2001}

A partir de 1996, num processo finalizado em 1997, o DNAEE definiu para cada concessionária de distribuição de energia elétrica os critérios para a classificação dos consumidores residenciais na nova Subclasse Residencial Baixa Renda que continuariam a receber a Tarifa Social. A definição dos critérios de classificação dos consumidores de "baixa renda" ocorreu de forma fragmentada, através da homologação quase integral pelo DNAEE das propostas de cada concessionária.

Em 1999, quando o novo modelo da ISEB já estava implementado e a maioria das empresas de distribuição de energia elétrica já privatizadas, a ANEEL determinou (Nota Técnica n. ${ }^{\circ}$ 021/1999-SRC/ANEEL, de 01/09/99) a realização de um estudo sobre os resultados da implementação da tarifa baixa renda. Esse estudo constatou que a política de aplicação da Tarifa Social, definida em 1996, apresentava deficiências em relação aos objetivos iniciais, em decorrência da fragmentação dos critérios de aplicação. Essas deficiências haviam gerado resultados que eram inconsistentes em nível nacional e demonstravam a inadequação do modelo, pois:

a) Os consumidores da Subclasse baixa renda representavam $38,66 \%$ do total dos consumidores residenciais do Brasil;

b) A região sudeste, a mais rica do Brasil, apresentava o maior índice de consumidores de "baixa renda", chegando a 50,94\% dos consumidores da classe residencial;

c) O Estado de Minas Gerais, área de concessão da Companhia Energética de Minas Gerais (CEMIG), apresentava o índice de $80,59 \%$ dos consumidores residenciais, classificados na subclasse de baixa renda.

d) O Estado do Piauí, área de concessão da Companhia Energética do Piauí (CEPISA), apresentava o índice de $0,13 \%$ de consumidores residenciais classificados na subclasse de baixa renda;

e) As concessionárias Companhia Força e Luz Cataguazes - Leopoldina (CFLCL) e Companhia de Eletricidade Nova Friburgo (CENF) não apresentavam nenhum consumidor residencial classificado na subclasse de baixa renda, em suas área de concessão, de acordo com os critérios estabelecidos nas Portarias do DNAEE; 
As distorções ocorriam também em nível regional, tal como o verificado entre a Companhia Energética de Goiás (CELG) e a Companhia Energética de Brasília (CEB), eis que a primeira apresentava um índice de $0,55 \%$ dos consumidores residenciais na subclasse baixa renda e a segunda onde o padrão de renda das famílias é muito mais elevado possuía $38,51 \%$ dos consumidores beneficiados com descontos. Outro exemplo consistia na situação da Companhia Energética de Alagoas (CEAL) que apresentava $1,95 \%$ de consumidores na subclasse residencial de baixa renda, enquanto a SAELPA S/A de Eletrificação da Paraíba possuía 43,98\%.

Era possível identificar esse desequilíbrio quanto ao universo de beneficiados com a concessão dos descontos da Tarifa Social nas diferentes distribuidoras, mesmo restringindo essa análise à região Sudeste, conforme o Quadro 9.

\begin{tabular}{|c|c|c|c|}
\hline Região SE & $\begin{array}{c}\text { Total de } \\
\text { Unidades } \\
\text { Consumidoras } \\
\text { Residenciais }\end{array}$ & $\begin{array}{c}\text { Unidades } \\
\text { Consumidoras } \\
\text { Residenciais } \\
\text { Baixa Renda }\end{array}$ & $\begin{array}{l}\text { Percentual de Baixa } \\
\text { Renda }\end{array}$ \\
\hline Caiuá Serviços de Eletricidade S/A & 127.577 & 459 & $0,36 \%$ \\
\hline \multicolumn{4}{|l|}{$\begin{array}{l}\text { Cia de Eletricidade de Nova Friburgo } \\
\left({ }^{*}\right)\end{array}$} \\
\hline Cia de Eletricidade do Rio de Janeiro & 1.193.108 & 76.690 & $6,43 \%$ \\
\hline $\begin{array}{l}\text { Companhia Energética de Minas } \\
\text { Gerais }\end{array}$ & 3.700 .582 & 2.982 .391 & $80,59 \%$ \\
\hline $\begin{array}{l}\text { Cia Energética de São Paulo } \\
\text { (Elektro) }\end{array}$ & 1.226 .593 & 586.456 & $47,81 \%$ \\
\hline \multicolumn{4}{|l|}{$\begin{array}{l}\text { Cia Força e Luz Cataguases } \\
\text { Leopoldina }\left(^{*}\right)\end{array}$} \\
\hline Cia Jaguari de Energia & 15.281 & 1.539 & $10,07 \%$ \\
\hline Cia Luz e Força de Mococa & 23.906 & 748 & $3,13 \%$ \\
\hline Cia Luz e Força Santa Cruz & 102.701 & 41.702 & $40,61 \%$ \\
\hline Cia Nacional de Energia Elétrica & 56.082 & 600 & $1,07 \%$ \\
\hline $\begin{array}{l}\text { Companhia Paulista de Energia } \\
\text { Elétrica }\end{array}$ & 27.519 & 2.842 & 10,33 \\
\hline $\begin{array}{l}\text { Companhia Paulista de Força e } \\
\text { Luz }\left(^{* *}\right)\end{array}$ & 2.108 .137 & 1.135 .726 & $53,87 \%$ \\
\hline Cia Sul Paulista de Energia & 37.499 & 2.474 & $6,60 \%$ \\
\hline $\begin{array}{l}\text { Depto. Municipal de Eletricidade de } \\
\text { Poços de Caldas }\end{array}$ & 37.169 & 68 & $0,18 \%$ \\
\hline Eletropaulo Metropolitana & 5.105 .711 & 3.606 .756 & $70,64 \%$ \\
\hline
\end{tabular}




\begin{tabular}{|l|c|c|c|}
\hline Eletricidade de São Paulo S/A $\left.{ }^{* * *}\right)$ & & & \\
\hline Empresa Bandeirante de Energia S/A & 1.773 .168 & 978.185 & $\mathbf{5 5 , 1 7 \%}$ \\
\hline $\begin{array}{l}\text { Empresa de Eletricidade Vale } \\
\text { Paranapanema S/A }\end{array}$ & 97.548 & 641 & $\mathbf{0 , 6 6 \%}$ \\
\hline Empresa Elétrica Bragantina S/A & 59.735 & 3.172 & $\mathbf{5 , 3 1 \%}$ \\
\hline $\begin{array}{l}\text { Empresa Luz e Força Santa Maria } \\
\text { S/A }\end{array}$ & 32.128 & 1.641 & $\mathbf{5 , 1 1 \%}$ \\
\hline Espírito Santo Centrais Elétricas S/A & 604.369 & 30.019 & $\mathbf{4 , 9 7 \%}$ \\
\hline Light - Serviços de Eletricidade S/A & 2.528 .265 & 152.894 & $\mathbf{6 , 0 5 \%}$ \\
\hline Total da Região:SE & 18.857 .078 & 9.605 .003 & $\mathbf{5 0 , 9 4 \%}$ \\
\hline Total Geral & 36.775 .581 & 14.319 .353 & $\mathbf{3 8 , 9 4 \%}$ \\
\hline
\end{tabular}

Quadro 9 - Consumidores da subclasse residencial Baixa Renda (\%).

Fonte: elaborado por Ramalho (2002)

Os dados obtidos nesse estudo foram considerados como "surpreendentes" pela agência reguladora, que chegou a colocar alguns deles sob suspeita, levando à solicitação de confirmação dos dados a algumas distribuidoras de energia elétrica, mantendo-se o quadro referido acima (ANEEL, 1999).

Segundo Correa (1998), apesar da ampla redução do universo de beneficiários dos descontos da Tarifa Social, bem como dos próprios descontos definidos pelo DNAEE em 1996/1997, quando a maioria das empresas ainda eram estatais, algumas concessionárias, apos a privatização, pleitearam a ampliação da redução desse universo junto ao órgão regulador. Pela proposta de alteração de critérios de defendida pelos novos controladores da concessionária LIGHT/RJ, cerca de um milhão de pessoas perderiam o desconto nos primeiros quilowatts-hora consumidos. Isso teria um reflexo no faturamento da empresa equivalente a cerca de $3 \%$ da sua previsão de receita anual. A Eletropaulo também pleiteou a ANEEL alteração nos critérios de concessão dos descontos referentes à Tarifa Social, obtendo autorização judicial (Ramalho, 2002) que permitiu a esta concessionária, que atende a aproximadamente 4.500 .000 consumidores, reduzir para 400.000 o número de consumidores enquadrados como baixa renda, quando este benefício atingia 2.700.000 clientes, com importante reflexo para o aumento de sua receita.

O desequilíbrio na concessão de descontos da Tarifa Social entre as diversas concessionárias identificado no estudo de 1998, pode ser explicado pela diversidade de critérios de enquadramento de consumidores na Subclasse Baixa Renda que foram 
sugeridos pelas próprias firmas, tais como: a) padrão de moradia (madeira/alvenaria, favelas); b) residência na periferia das cidades; c) metragem do imóvel; d) posse de linha telefônica; e) número de tomadas elétricas do imóvel.

A concessão da Tarifa Social aos consumidores residenciais de baixa renda quase sempre utilizou como critério, ao menos, o consumo mensal em $\mathrm{kWh}$ de cada unidade consumidora, que deveria ser inferior a um dado valor.

Mesmo nas iniciativas pioneiras, anteriores a 1985, das concessionárias estatais paulistas Eletropaulo, Companhia Energética de São Paulo (CESP) e Companhia Paulista de Força e Luz (CPFL) e pela Centrais Elétricas de Santa Catarina S/A (CELESC) já era utilizado o critério de consumo mensal. Para as concessionárias paulistas o limite de 200 kWh mensais foi aumentado, em 1996, para 220 kWh, limite suficiente para incluir $60 \%$ dos usuários residenciais como potenciais beneficiários da Tarifa Social.

\begin{tabular}{|l|c|c|c|c|}
\hline \multicolumn{1}{|c|}{$\begin{array}{c}\text { Faixa de Consumo } \\
\text { (kWh/mês) }\end{array}$} & \multicolumn{2}{c|}{ Consumo } & \multicolumn{2}{c|}{ Consumidores } \\
\hline & KWh/mês & \% do total & No abs. $^{\text {\% do total }}$ \\
\hline 0 a 10 & 19.196 & 0.03 & 34.153 & 10,29 \\
\hline 11 a 100 & 3.470 .577 & 5,48 & 50.637 & 15,26 \\
\hline 101 a 200 & 21.327 .759 & 33,65 & 140.838 & 42,45 \\
\hline 201 a 300 & 17.030 .892 & 26,87 & 70.213 & 21,16 \\
\hline 301 a 400 & 7.856 .275 & 12,40 & 22.947 & 6,92 \\
\hline 401 a 500 & 3.377 .683 & 5,33 & 7.611 & 2,29 \\
\hline 501 a 1000 & 2.961 .772 & 4,67 & 4.777 & 1,44 \\
\hline Mais de 1000 & 7.333 .761 & 11,57 & 579 & 0,17 \\
\hline Total & 63.377 .915 & 100,00 & 331.775 & 100,00 \\
\hline
\end{tabular}

Quadro 10 - Consumo médio mensal do segmento de baixa renda.

Fonte: elaborado por França (1999) 


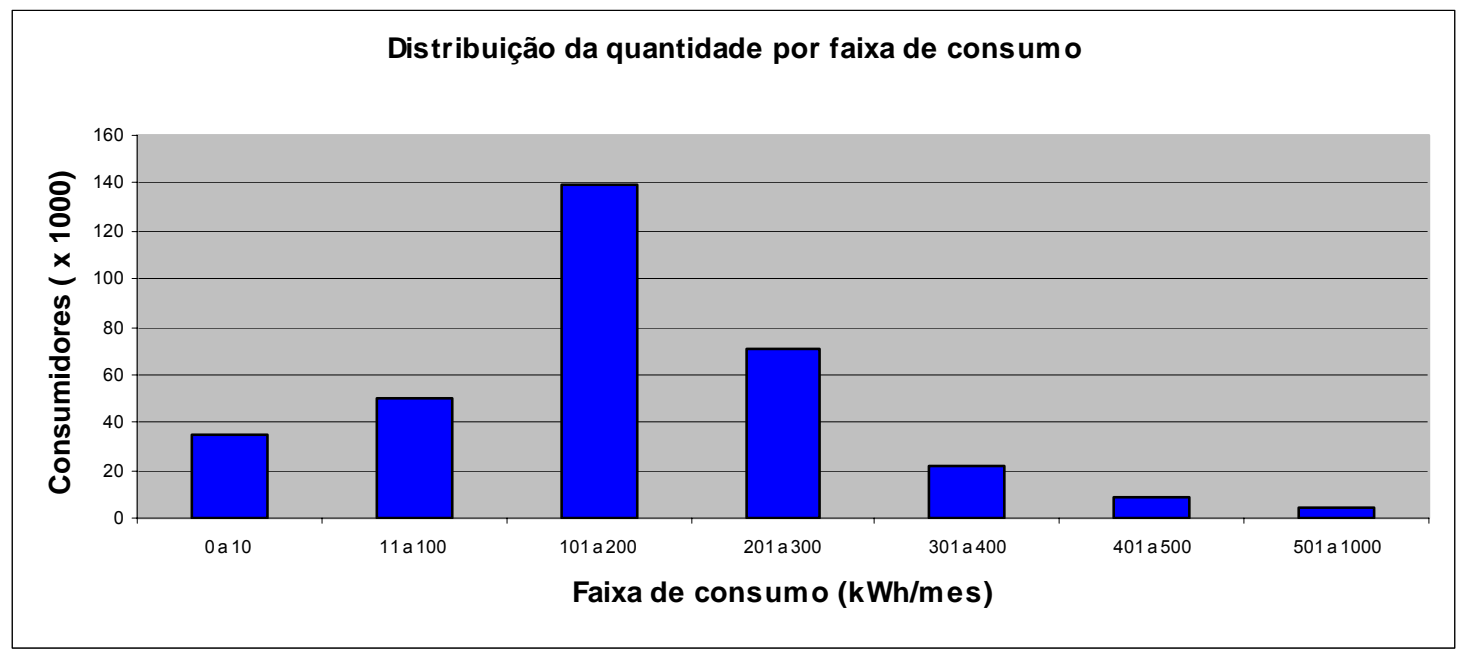

Figura 12 - Distribuição de consumidores de baixa renda - faixas de consumo.

Fonte: elaborado por França (1999)

A utilização do critério de consumo mensal, expresso em $\mathrm{kWh}$, para inferir a renda do usuário de "baixa renda" fundamenta-se na pressuposição de que baixos níveis de consumo resultam de baixos níveis de renda, o que justificaria a concessão da Tarifa Social. Além desse aspecto, o consumo mensal é tido como critério desejável devido à simplicidade cadastral e de fiscalização pelas concessionárias distribuidoras de energia elétrica. Outra justificativa freqüente para a utilização de tal critério de classificação seria o estímulo ao consumidor para manter um baixo consumo de energia elétrica (Bitu, 1985).

O consumo médio mensal aumentou significativamente entre 1985 (quando 81 $\%$ dos usuários residenciais consumiam menos de 120 kWh mensais) e 1991 (quando menos de $30 \%$ consumiam menos de $120 \mathrm{kWh}$ mensais), apesar de não ser verificado um aumento na renda média das famílias proporcional a essa expansão de consumo.

\begin{tabular}{|l|c|c|}
\hline \multirow{2}{*}{ Faixa de Consumo } & \multicolumn{2}{|c|}{ Ano da pesquisa (Eletropaulo) } \\
\cline { 2 - 3 } & $\mathbf{1 9 8 4}$ & $\mathbf{1 9 9 1}$ \\
\hline Até $50 \mathrm{kWh} / \mathrm{mês}$ & $50,0 \%$ & $6,5 \%$ \\
\hline De 51 a 120 kWh/mês & $31,5 \%$ & $23,1 \%$ \\
\hline Mais de 120 kWh/mês & $18,5 \%$ & $70,4 \%$ \\
\hline
\end{tabular}

Quadro 11 - Consumo médio mensal: segmento residencial.

Fonte: elaborado por França (1999) 
A evolução do consumo de energia elétrica residencial entre 1985 e 1991 pode ser explicada não necessariamente pelo aumento da renda das famílias, mas sim pela acumulação de aparelhos eletrodomésticos. Uma pesquisa realizada em 1979 por Droichi, M. \& Higa, T. T. ${ }^{3}$, citados por França (1999), sobre residências com renda entre 2 e 3 salários mínimos constatou que $28 \%$ dos domicílios possuía refrigeradores, $50 \%$ televisores e $64 \%$ ferros elétricos. Andrade \& Lins ${ }^{4}$, citados por França (1999) realizaram pesquisa em 1985 com o mesmo extrato de renda, encontrando níveis de posse de $56 \%$, $62 \%$ e $76 \%$ respectivamente de tais equipamentos em residências.

Assim, para um dado nível de renda, residências parecem acumular mais aparelhos elétricos ao longo do tempo, o que leva a um maior uso de eletricidade em relação à renda. Evidentemente, rendas mais altas permitem maior uso de eletricidade, mas, mesmo quando se trata de pequenos usuários e residências de baixa renda, o consumo parece crescer a uma taxa superior ao crescimento da renda real, devido ao aumento no estoque de aparelhos elétricos (França, 1999).

\begin{tabular}{|l|c|c|c|c|}
\hline \multirow{2}{*}{ Aparelho } & \multicolumn{3}{c|}{ Ano da pesquisa } \\
\cline { 2 - 5 } & $\mathbf{1 9 8 4}$ & $\mathbf{1 9 8 5}$ & $\mathbf{1 9 8 7}$ & $\mathbf{1 9 9 1}$ \\
\hline TV preto e branco & $62,5 \%$ & & & \\
\hline TV em cores & $4,2 \%$ & & & \\
\hline TV (total) & $66,7 \%$ & $81,6 \%$ & & \\
\hline Ferro elétrico & $66,7 \%$ & $77,6 \%$ & $88,2 \%$ & \\
\hline Chuveiro & $47,9 \%$ & $61,2 \%$ & $73,5 \%$ & $83,6 \%$ \\
\hline Geladeira & $41,7 \%$ & $59,2 \%$ & $64,7 \%$ & $79,5 \%$ \\
\hline Rádio & $39,6 \%$ & $66,3 \%$ & $70,6 \%$ & \\
\hline Aparelho de som & $19,8 \%$ & $30,6 \%$ & $20,6 \%$ & \\
\hline Liquidificador & $17,7 \%$ & $45,9 \%$ & $58,8 \%$ & \\
\hline Máquina de costurar & $1,0 \%$ & $15,3 \%$ & $20,6 \%$ & \\
\hline
\end{tabular}

Quadro 12 - Posse de eletrodomésticos nas residências atendidas (Eletropaulo S.A). Fonte: elaborado por França (1999)

${ }^{3}$ DROICH, M.; HIGA, T.T. Consumo domiciliar de energia em favelas de São Paulo. São Paulo: Universidade de São Paulo, Instituto de Física, 1980.

${ }^{4}$ ANDRADE, C.S.; LINS, M.P.E. Análise do consumo de energia residencial no estado do Rio de Janeiro. In: CONGRESSO BRASILEIRO DE PLANEJAMENTO ENERGÉTICO, 1, Campinas, 1989. Anais. s.n.t. 
Andrade \& Lobão (1997) analisando a evolução do consumo residencial de energia elétrica no Brasil no período 1963/95, estimaram as elasticidades renda e preço desta demanda, usando o modelo econométrico estimado para fazer projeções das quantidades demandadas desta energia no período 1997/2005. O modelo utilizado considerou a influência sobre a demanda que a queda no preço real dos eletrodomésticos e o aumento da posse destes equipamentos nas residências, identificando, respectivamente, as elasticidades desses parâmetros em função da demanda de eletricidade, obtendo o seguinte resultado:

$$
\begin{aligned}
& C_{t}=-0,5084 p_{t}+0,2132 y_{t}-0,1864 p e_{t} \\
& p_{t}=\text { tarifa de energia elétrica } \\
& y_{t}=\text { renda das famílias } \\
& p_{t}=\text { preço dos eletrodomésticos }
\end{aligned}
$$

Verifica-se que a demanda residencial de energia elétrica no Brasil, embora sensível na forma esperada às variações da tarifa, da renda e dos preços dos eletrodomésticos, é bastante inelástica em relação às variáveis explicativas da quantidade demandada deste serviço. As estimativas feitas por Modiano (1984) citado por Andrade \& Lobão (1997) para estes parâmetros eram -0,118 e -0,4027 para as elasticidades preço de curto e longo prazos, respectivamente, e 0,332 e 1,133 para as elasticidades respectivas da renda.

A inelasticidade identificada nesse estudo entre o consumo de energia elétrica e o seu preço (tarifa) é consistente com dois fatores:

a) a identificação da ISEB como um monopólio maximizador de quantidade (em função de restrições técnicas) que opera atendendo a totalidade da demanda dos consumidores, ou seja, em um trecho da curva de demanda agregada caracterizada pela inelasticidade em relação ao preço (tarifa) da energia elétrica.

b) a ausência de substitutos próximos da energia elétrica para os consumidores, aliada à essencialidade desse bem na vida moderna.

Com a criação da Subclasse Residencial Baixa Renda em 1995 e a definição de critérios de enquadramento apresentados pelas concessionárias em 1996, passou 
a ser utilizado, por diversas concessionárias, o critério da potência dos equipamentos (em kW) como indicativo do nível de renda do consumidor (ANEEL, 1998).

A "potência do consumidor" corresponde à soma das potências de todos equipamentos elétricos da residência. O fundamento do critério de potência é que a posse de equipamentos elétricos é um indicativo mais preciso da renda do consumidor. Dados da PNAD 1999 demonstram que nos domicílios com renda inferior a três salários mínimos, $43 \%$ não dispunham de aparelhos de rádio, 53,1\% dos domicílios não possuíam aparelhos de televisão e 58,1\% não possuíam geladeiras, demonstrando que a posse de equipamentos é influenciado pela renda da família.

\begin{tabular}{|c|c|c|c|c|c|c|c|c|}
\hline \multirow[b]{2}{*}{$\begin{array}{c}\text { Equipamento e } \\
\text { Situação de } \\
\text { Domicilio }\end{array}$} & \multirow[b]{2}{*}{ No Abs. } & \multirow[b]{2}{*}{$\begin{array}{l}\% \text { do } \\
\text { Total }\end{array}$} & \multicolumn{6}{|c|}{ Classes de Rendimento (em salários mínimos (1)) } \\
\hline & & & Até 1 & 1 a 3 & 3 a 5 & $5^{\mathrm{a}} 10$ & $\begin{array}{c}+ \text { de } \\
10\end{array}$ & $\begin{array}{l}\text { Sem } \\
\text { Decla.l } \\
\text { Sem } \\
\text { Renda }\end{array}$ \\
\hline Rádio & 478.860 & 4,9 & 13,4 & 29,6 & 25,1 & 18,1 & 8,4 & 5,4 \\
\hline Urbano & 440.589 & 4,8 & 12,6 & 28,3 & 25,7 & 19,1 & 8,8 & 5,5 \\
\hline Rural & 38.271 & 6,1 & 22,2 & 44,4 & 17,7 & 6,7 & 4,4 & 4,6 \\
\hline Televisão & 367.706 & 3,8 & 17,1 & 36,0 & 20,7 & 16,1 & 4,4 & 5,7 \\
\hline Urbano & 309.920 & 3,4 & 14,9 & 32,8 & 22,4 & 18,3 & 5,3 & 6,3 \\
\hline Rural & 57.786 & 9,2 & 29,4 & 52,9 & 11,8 & 4,4 & - & 1,5 \\
\hline Geladeira & 346.335 & 3,5 & 16,7 & 41,4 & 23,2 & 7,7 & 3,2 & 7,8 \\
\hline Urbano & 293.667 & 3,2 & 16,0 & 40,2 & 23,0 & 8,8 & 3,5 & 8,5 \\
\hline Rural & 52.668 & 8,4 & 21,0 & 48,4 & 24,2 & 1,6 & 1,6 & 3,2 \\
\hline $\begin{array}{l}\text { Máquina de Lava } \\
\text { Roupa }\end{array}$ & 4.790 .305 & 49,1 & 5,7 & 24,7 & 27,0 & 27,0 & 11,3 & 4,3 \\
\hline Urbano & 4.340 .682 & 47,5 & 5,5 & 23,2 & 26,9 & 28,0 & 11,8 & 4,6 \\
\hline Rural & 449.623 & 71,9 & 7,0 & 39,1 & 28,3 & 17,2 & 6,4 & 2,0 \\
\hline
\end{tabular}

Quadro 13 - Ausência de equipamentos x rendimento mensal - Estado de São Paulo 1998.

Fonte: Campelo et al. (2003)

Buscando investigar a correlação entre renda familiar e consumo mensal de energia elétrica, como fundamento para a concessão da Tarifa Social, o Tribunal de Contas da União-TCU procedeu a um estudo buscando avaliar a correlação entre consumo residencial de energia (em KWh) e renda per capita (em $\mathrm{R} \$$ ), com base nos 
dados da Pesquisa Nacional por Amostragem de Domicílios (PNAD-IBGE) e a Pesquisa de Padrões de Vida (PPV-IBGE).

O valor do coeficiente de correlação de Pearson obtido foi de 0,015, estatisticamente significativo apenas com $49 \%$ de confiabilidade e um coeficiente $\mathrm{R}^{2}$ praticamente igual a zero, o que indica a inexistência de correlação entre as variáveis (Campelo et. al., 2003).

Tabela 1. Regressão linear: consumo domiciliar de energia elétrica versus renda.

\begin{tabular}{ccccc}
\hline Model & $\mathrm{R}$ & $\mathrm{R}$ Square & Adjusted R Square & Std. Error of the Estimate \\
\hline 1 & 0,047 & 0,002 & 0,002 & 209,85766
\end{tabular}

Fonte: elaborado por Campelo et al. (2003)

Um exemplo de distorções que podem ser verificadas quando são utilizados esses dois critérios é o fato de que $28 \%$ dos domicílios com renda inferior a 1 salário mínimo não receberiam nenhum desconto nas tarifas de energia elétrica por apresentarem consumo superior a 220 kWh (Campelo et. al., 2003), provavelmente por se tratarem de habitações multi-familiares.

A baixa capacidade de previsão da renda familiar em função do consumo mensal de energia, um critério quase universalmente utilizado na ISEB para concessão da Tarifa Social, é demonstrada por outros modelos avaliados no mesmo estudo e utilizado por algumas concessionárias.

A utilização nesse estudo de critérios adicionais ao de consumo mensal permitiu a obtenção de melhores resultados em termos de correlação à renda, porém, em termos absolutos, com pouco poder explicativo. A utilização do critério de consumo mensal per capita em função da renda implicou em um $\mathrm{R}^{2}$ de 0,014 .

Tabela 2. Regressão linear: consumo de energia elétrica per capita versus renda.

\begin{tabular}{ccccc}
\hline Model & $\mathrm{R}$ & $\mathrm{R}$ Square & Adjusted R Square & Std. Error of the Estimate \\
\hline 1 & 0,118 & 0,014 & 0,014 & 105,45928 \\
\hline
\end{tabular}

Fonte: elaborado por Campelo et al.(2003) 
Esse estudo também avaliou o consumo domiciliar de energia em função do número de moradores e ao número de cômodos do domicílio. Essas variáveis apresentaram $R^{2}$ de 0,123 , que apesar de baixo é muito superior ao valor de 0,002 obtido na regressão de consumo total em função da renda total.

Tabela 3. Regressão linear: consumo em função de renda per capita, $n^{\circ}$ de moradores e $\mathrm{n}^{\circ}$ de cômodos.

\begin{tabular}{ccccc}
\hline Model & $\mathrm{R}$ & $\mathrm{R}$ Square & Adjusted R Square & Std. Error of the Estimate \\
\hline 1 & 0,351 & 0,123 & 0,122 & 196,843 \\
\hline
\end{tabular}

Fonte: elaborado por Campelo et al. (2003)

A utilização desses mesmos critérios em função do consumo per capita apresentou um R2 de 0,191, conforme Tabela 4.

Tabela 4. Regressão linear: consumo per capita como função de renda per capita, número de moradores e número de cômodos.

\begin{tabular}{ccrcc}
\hline Model & $\mathrm{R}$ & $\mathrm{R}$ Square & Adjusted R Square & Std. Error of the Estimate \\
\hline 1 & 0,437 & 0,191 & 0,190 & 100,670 \\
\hline
\end{tabular}

Fonte: elaborado por Campelo et al.(2003)

O estudo avaliou também a correlação entre consumo mensal de energia e renda, ambos per capita. O coeficiente de correlação de Pearson obtido para essas variáveis é significativo com $99 \%$ de confiabilidade, com um valor de 0,12 , o que representa um maior poder explicativo, porém ainda pequeno em termos absolutos, conforme Figura 13. 


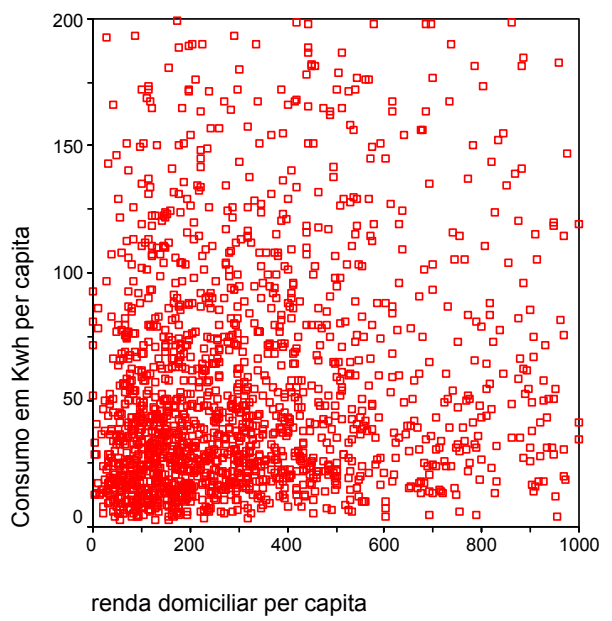

Figura 13 - Consumo per capita de energia elétrica versus renda per capita.

Fonte: elaborado por Campelo et al. (2003)

Em 2000 um estudo realizado pelo convênio USP/ANEEL, avaliou a eficácia do critério adicional ao critério de consumo mensal de utilizar-se o critério do tipo de ligação monofásica ou bifásica, especificamente para a Elektro S/A que atende grande parte do interior do Estado de São Paulo. Esse critério também é utilizado com freqüência para a classificação dos consumidores que teriam direito à Tarifa Social, que seriam apenas aqueles com ligação monofásica (54\% do total dos consumidores residenciais), por ser esse o tipo de ligação mais simples e de menor custo para a concessionária.

Esse estudo identificou que o comportamento médio dos consumidores da categoria bifásica apresentou um nível de consumo mensal similar à categoria monofásica, com maior freqüência de consumo entre 150 - $200 \mathrm{kWh} / \mathrm{mês}$ para ambos e médias mensais com uma diferença de 45 a $60 \mathrm{kWh}$. Não foram identificadas diferenças substanciais entre ambas classes quanto ao consumo de energia e à posse de equipamentos elétricos. A conclusão do estudo é que o critério do tipo de ligação é apenas um critério técnico correlacionado com a data de instalação das unidades consumidoras, já que a maioria dos consumidores mais antigos possuem ligação monofásica e os novos consumidores possuem ligação bifásica (Sauer et al., 2000). 
Conforme Ramalho (2002) em um estudo da FIPE contratado pela ANEEL em $2000^{5}$, sobre os critérios de classificação dos consumidores para a concessão da Tarifa Social, foram usados os dados fornecidos pelas concessionárias sobre o percentual de seus consumidores beneficiados com a Tarifa Social e dados do IPEA sobre domicílios pobres. Esse estudo constatou que para algumas regiões o critério do consumo mensal, largamente utilizado em todas as concessionárias, garante a inclusão de uma parte importante da população alvo, mas em outras ela é insuficiente, deixando de fora parte significativa de possíveis beneficiários.

\begin{tabular}{|c|c|c|}
\hline Estado & $\begin{array}{l}\text { Domicílios Pobres \% } \\
\text { (IPEA) }\end{array}$ & $\begin{array}{c}\text { Baixa Renda } \\
\% \text { (concessionária) }\end{array}$ \\
\hline Acre & 42,56 & 78,45 \\
\hline Alagoas & 52,21 & 7,75 \\
\hline Amapá & 36,78 & 52,94 \\
\hline Amazonas & 44,75 & 40,77 \\
\hline Bahia & 50,40 & 2,40 \\
\hline Ceará & 51,26 & 11,96 \\
\hline Distrito Federal & 19,91 & 38,86 \\
\hline Espírito Santo & 22,82 & 5,27 \\
\hline Goiás & 26,81 & 0,51 \\
\hline Maranhão & 56,76 & 48,59 \\
\hline Mato Grosso & 27,94 & 14,32 \\
\hline Mato Grosso do Sul & 26,92 & 13,02 \\
\hline Minas Gerais & 21,51 & 75,92 \\
\hline Pará & 54,64 & 25,66 \\
\hline Paraíba & 47,09 & 32,42 \\
\hline Paraná & 22,78 & 8,25 \\
\hline Pernambuco & 49,93 & 41,13 \\
\hline Piauí & 55,83 & 0,11 \\
\hline Rio de Janeiro & 18,16 & 4,85 \\
\hline Rio Grande do Norte & 44,28 & 21,28 \\
\hline Rio Grande do Sul & 19,19 & 7,88 \\
\hline Rondônia & 39,25 & 39,59 \\
\hline Roraima & 18,93 & 40,77 \\
\hline Santa Catarina & 15,92 & 1,56 \\
\hline São Paulo & 14,66 & 46,56 \\
\hline Sergipe & 47,85 & 8,52 \\
\hline Tocantins & 58,49 & 1,28 \\
\hline
\end{tabular}

Quadro 14 - Domicílios de baixa renda e domicílios com a Tarifa Social.

Fonte: elaborado por Ramalho (2002)

Segundo esse estudo as concessionárias de vinte estados possuem um percentual muito maior de consumidores que deveriam ser atendidos pelo programa, concessionárias de seis estados concedem a Tarifa Social a um percentual de

\footnotetext{
${ }^{5}$ FUNDAÇÃO INSTITUTO DE PESQUISAS ECONÔMICAS. Projeto: metodologia para definição de domicílios de baixa renda. Brasília, fev. 2000.
} 
consumidores superior ao percentual de consumidores de baixa renda e no Estado de Rondônia existe um equilíbrio entre ambos (Ramalho, 2002).

Com a crise de abastecimento de energia elétrica em 2001 foram iniciados estudos visando à reforma do modelo da ISEB que foi implementado em 1996. A questão da Tarifa Social foi retomada pelo Governo Federal, sendo estabelecidas diretrizes para a eliminação das distorções na concessão do subsídio ao consumidor residencial de energia elétrica identificadas já em 1999 e nos anos subsequentes.

Entre junho de 2001 e fevereiro de 2002, o consumo de energia elétrica ficou sujeito a forte contingenciamento. Embora o volume de chuvas no verão de 2001 tenha sido inferior à média de longo termo, particularmente na região Nordeste, não se pode atribuir unicamente a essa circunstância o racionamento imposto à população pois os investimentos na expansão da geração e da transmissão nos anteriores foram insuficientes na década anterior (Rosa, 2002). Nos anos anteriores ao racionamento, os reservatórios foram explorados sistematicamente praticamente em capacidade plena, comprometendo o atendimento futuro da demanda por energia elétrica (MME, 2003).

Durante a crise de abastecimento de 2001 o Governo Federal estabeleceu tratamento diferenciado aos consumidores residenciais da subclasse baixa renda com a edição da Medida Provisória n. 2198-5, de 24 de agosto de 2001, visando evitar que essa classe de consumidores sofresse os efeitos do Plano de Racionamento. Os critérios de classificação dos consumidores nesta subclasse permaneceram os mesmos definidos em 1996, mas foram isentados da meta $20 \%$ de redução de consumo de energia elétrica imposta a todos os outros usuários, além de receberem um "bônus" na conta de energia elétrica na proporção de 2:1 para cada kWh economizados, o que representava em muitos casos o recebimento de contas quitadas integralmente. Os demais usuários residenciais estavam sujeitos à meta de $20 \%$ e recebimento de bônus na proporção de 1:1 de economia sobre a média de consumo nos três meses anteriores.

O Comitê de Revitalização do Modelo do Setor Elétrico (CRMSE), criado pela Câmara de Gestão da Crise de Energia Elétrica (GCE) através da Resolução n. 18, de 22 de junho de 2001, apresentou em 2002 uma proposta de nova regulamentação da Tarifa Social através de Lei que estabelecesse disciplina uniforme em nível nacional 
para a tarifa social de baixa renda. Essa Lei segundo aquele estudo deveria observar as seguintes premissas para a concessão da Tarifa Social (CRMSE, 2002):

a) os hábitos de consumo de energia elétrica das diversas regiões do País;

b) a freqüência de ocupação dos imóveis residenciais;

c) a definição de linhas de pobreza para as diversas regiões do País.

A revisão da política tarifaria de concessão dos descontos da Tarifa Social em 2001 foi motivada pela inconsistência do modelo implementado em 1996, pela pressão popular decorrente das medidas impopulares do Plano de Racionamento e o aumento real das tarifas residenciais nos anos imediatamente anteriores, que apresentaram um aumento real médio de $81,2 \%$ (em relação ao IPC-FIPE).

\begin{tabular}{|l|r|r|r|r|r|r|r|r|r|}
\hline $\begin{array}{l}\text { Classe de } \\
\text { consumo }\end{array}$ & $\mathbf{1 9 9 5}$ & $\mathbf{1 9 9 6}$ & $\mathbf{1 9 9 7}$ & $\mathbf{1 9 9 8}$ & $\mathbf{1 9 9 9}$ & $\mathbf{2 0 0 0}$ & $\begin{array}{l}\mathbf{2 0 0 1} \\
\mathbf{1 . b i m} .\end{array}$ & $\begin{array}{l}\text { Variação } \\
\text { \% }\end{array}$ & $\begin{array}{l}\text { Variação } \\
\text { Excedente } \\
\text { ao IPC- } \\
\text { FIPE } \\
\text { (44,3\%) }\end{array}$ \\
\hline Residencial & 76,26 & 103,63 & 119,8 & 126,19 & 139,19 & 158,84 & 171,93 & 125,5 & 81,2 \\
\hline Industrial & 43,59 & 50,45 & 54,61 & 56,54 & 63,08 & 71,09 & 74,19 & 70,2 & 25,9 \\
\hline Comercial & 85,44 & 99,62 & 107,99 & 111,6 & 121,62 & 136,87 & 144,96 & 69,7 & 25,4 \\
\hline Rural & 55,19 & 62,21 & 67,27 & 69,25 & 75,47 & 85,34 & 90,74 & 64,4 & 20,1 \\
\hline $\begin{array}{l}\text { Poderes } \\
\text { Públicos }\end{array}$ & 84,07 & 98,34 & 106,1 & 109,77 & 119,5 & 136,09 & 141,91 & 68,8 & 24,5 \\
\hline $\begin{array}{l}\text { Iluminação } \\
\text { Pública }\end{array}$ & 51,59 & 60,31 & 65,31 & 68,53 & 75,49 & 85,81 & 90,47 & 75,4 & 31,1 \\
\hline $\begin{array}{l}\text { Serviço } \\
\text { Público }\end{array}$ & 50,45 & 57,47 & 62,65 & 64,99 & 70,57 & 79,61 & 83,59 & 65,7 & 21,4 \\
\hline $\begin{array}{l}\text { Consumo } \\
\text { próprio }\end{array}$ & 69,59 & 65,92 & 69,5 & 70,76 & 85,83 & 80,17 & 75,64 & 8,7 & $-35,6$ \\
\hline
\end{tabular}

Quadro 15 - Evolução das tarifas médias setoriais e inflação.

Fonte: elaborado por Sauer (2002)

A tarifa de energia elétrica da classe residencial além de ser a mais elevada em 2001 (em 1996 era apenas a terceira mais cara) em relação às demais classes de consumo, sofreu o maior aumento no período posterior às privatizações das concessionárias de distribuição. Os consumidores que não estavam incluídos na classe "residencial baixa renda" e apresentavam pequenos consumos (30 e 50 $\mathrm{kWh} /$ mensais) sofreram reajustes reais (em relação ao IPC-FIPE, entre junho de 1994 
e Agosto de 2000) de $359,44 \%$ e $196,27 \%$ (Sauer, 2002), respectivamente. Os reajustes reais diminuem na medida em que são considerados maiores níveis de consumo, sendo que os usuários tarifados na classe "residencial" com consumo mensal de $500 \mathrm{kWh} /$ mensais sofreram um reajuste real de apenas 2,2\%, enquanto que aqueles com consumo superior a $700 \mathrm{kWh}$ tiveram reajustes $3,68 \%$ inferiores ao apurado pelo IPC-FIPE no período.

Os usuários tarifados na subclasse "residencial baixa renda" também sofreram reajustes superiores ao IPC-FIPE, especialmente aqueles com pequenos consumos mensais (30 e $50 \mathrm{kWh}$ ) que sofreram reajustes reais (em relação ao IPC-FIPE) de $78,55 \%$ e $56,34 \%$ respectivamente.

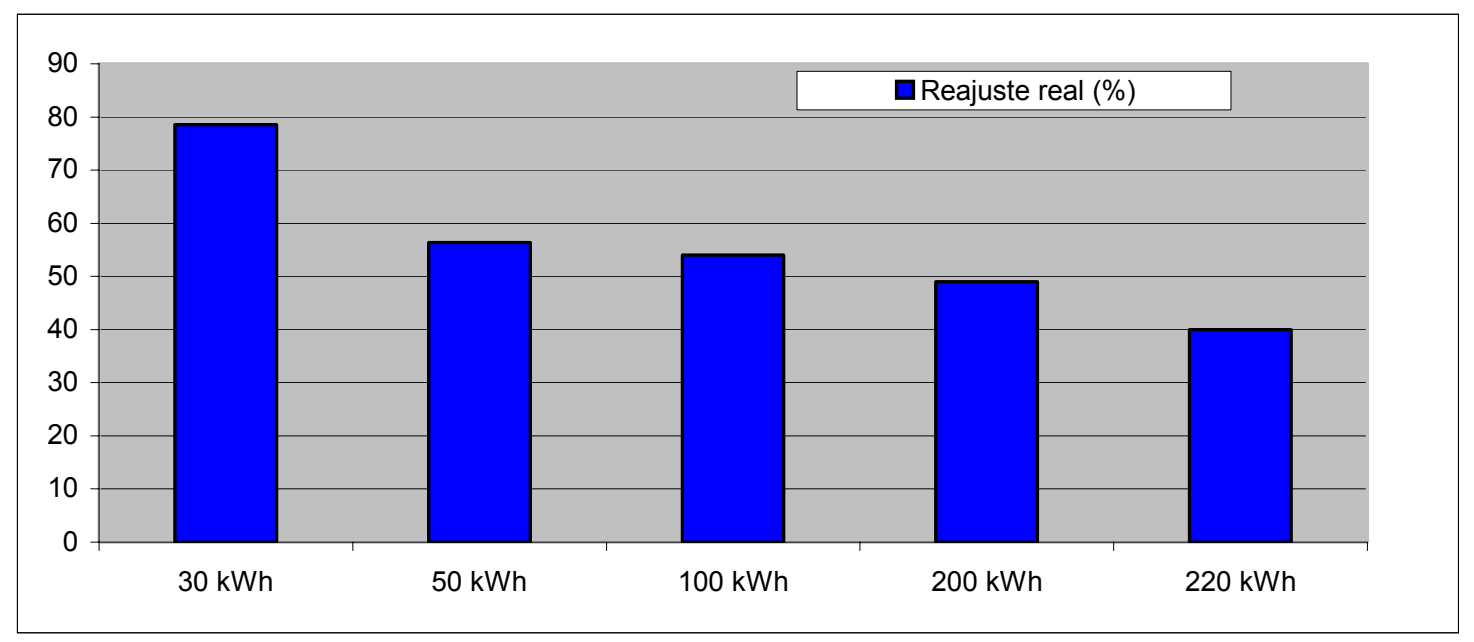

Figura 14 - Aumento real da tarifa "residencial baixa renda" por nível de consumo mensal.

Fonte: elaborado por Sauer (2002)

\subsubsection{Tarifa Social: período pós - 2002}

Com a edição da Lei $n^{\circ} 10.438$, de 26 de abril de 2002, a aplicação da Tarifa Social de energia elétrica foi alterada substancialmente. Pela primeira vez desde sua instituição, contava com base legal em sentido estrito e de aplicação uniforme em todo o país.

Além da uniformização e obrigatoriedade em todo território nacional a partir de 2002, a Tarifa Social teve seu universo de beneficiados alterado, em decorrência das 
novas exigências para o enquadramento na subclasse "baixa renda". Apesar da alteração quanto ao universo de consumidores beneficiados, não foram alterados os valores individuais do desconto, permanecendo com o mesmo percentual sobre o consumo.

\begin{tabular}{|c|c|}
\hline Faixa de consumo (kWh) & Descontos no preço do kWh \\
\hline $0-30$ & $65 \%$ \\
\hline $31-80$ & $40 \%$ \\
\hline $\begin{array}{c}\text { Acima de 81 até o limite } \\
\text { regional }^{*}\end{array}$ & $10 \%$ \\
\hline
\end{tabular}

Quadro 16 - Faixas de desconto para a Tarifa Social - 2003.

Fonte: elaborado por Campelo et al. (2003)

A definição de critérios para concessão do subsídio aos consumidores residenciais de energia elétrica passou a utilizar um sistema "misto", definindo um critério de consumo mínimo e impondo critérios adicionais para consumidores com consumo superior ao mínimo.

Com os novos critérios, todos os consumidores residenciais com consumo mensal de até $80 \mathrm{kWh}$ (média móvel de 12 meses), independentemente de sua renda ou quaisquer outras características, passam a receber automaticamente o desconto da Tarifa Social, na forma estabelecida pela ANEEL na Resolução $n^{\circ} 246$, de 02 de maio de 2002.

Os consumidores residenciais com consumo mensal entre 80 e $220 \mathrm{kWh}$ (média móvel de 12 meses) passaram a ter direito ao recebimento da tarifa social desde que, além do critério de consumo, preencham os demais requisitos definidos para o recebimento de subsídios definidos no programa "Auxílio Gás" do governo federal, criado pelo Decreto $n^{\circ} 4102$, de 25 de janeiro de 2002, na forma estabelecida na Resolução ANEEL n 485, de 30 de agosto de 2002:

a) seja inscrito do Cadastramento Único para Programas Sociais do Governo Federal, criado pelo Decreto n 3.877, de 24 de julho de 2001; ou

b) seja beneficiário dos programas "Bolsa Escola" ou "Bolsa Alimentação", ou esteja cadastrado como potencial beneficiário destes programas. 
Além de preencher os requisitos acima, a família do responsável pela unidade consumidora deve possuir renda mensal "per capita" máxima equivalente a meio salário mínimo. A aplicação do benefício incide sobre o consumo até o limite máximo regional estabelecido para cada concessionária, que varia de $140 \mathrm{kWh}$ até $220 \mathrm{kWh}$.

A Lei $n^{0} 10.438 / 2002$ isentou os consumidores residenciais de baixa renda de arcar com os custos relativos à contratação da capacidade de geração ou potência emergencial pela Comercializadora Brasileira de Energia Emergencial (CBEE) e da aquisição dessa energia emergencial (denominados de "Seguro Apagão"), da mesma forma que foram isentados no Plano de Racionamento em 2001.

A Lei $n^{\circ}$ 9.074/95 estabelece, em seu art. 35, que a estipulação de novos benefícios tarifários fica condicionada à previsão, em lei, da origem dos recursos necessários, já que as firmas não são obrigadas a arcar com esse custo ou com a perda de receita decorrente de novas regras.

Os recursos para a compensação às concessionárias e permissionárias de distribuição de energia elétrica seriam retirados da Reserva Global de Reversão (RGR), conforme disposto no art. $1^{\circ}$ do Decreto $n^{\circ} 4.336 / 02$. Foram estabelecidos, inclusive, procedimentos, condições e prazos para a homologação pela ANEEL dos valores que serviriam de base à contratação dos financiamentos junto à Eletrobrás pelas concessionárias e permissionárias que tivessem redução de receitas oriundas da nova classificação de unidades consumidoras na Subclasse Residencial Baixa Renda (Campelo et al., 2003).

A nova sistemática de concessão da Tarifa Social, implementada pela Lei $n^{\circ}$ 10.438/2002, foi objeto de auditoria do TCU em 2003 sobre a adequação desse programa. A principal conclusão desse estudo é que a baixa correlação entre renda familiar e consumo de energia elétrica (per capita ou absolutos), tradicionalmente utilizada na ISEB para a concessão da Tarifa Social e mantida pela legislação em 2002, não é a forma mais adequada de beneficiar as famílias de baixa renda (Campelo et al., 2003).

Essa conclusão não implicava que as mudanças implementadas eram inadequadas pois, ao menos para os consumidores com consumo mensal entre $80 \mathrm{e}$ $220 \mathrm{Kwh}$, os requisitos adicionais de pertencer ao cadastro de programas sociais do Governo Federal e a limitação de renda per capita permitiam que o benefício fosse 
concedido às famílias de baixa renda, segundo a definição mais ampla dos demais programas de distribuição de renda oficiais.

Segundo dado da ANEEL fornecidos ao TCU nesse estudo, a receita total das 64 concessionárias por mês é da ordem de $R \$ 3$ bilhões e desse total e $R \$ 1,2$ bilhões são decorrentes dos consumidores residenciais. Com a implementação dos novos critérios haverá uma perda líquida da ordem de $R \$ 48$ milhões por mês ( $R \$ 581$ milhões anuais), ou seja, uma perda percentual média de $1,58 \%$ sobre a receita total das concessionárias.

\begin{tabular}{|l|c|c|r|r|r|}
\hline \multirow{2}{*}{$\begin{array}{c}\text { Concessionárias } \\
\text { da Região }\end{array}$} & \multicolumn{1}{|c|}{ Receita total } & \multicolumn{2}{|c|}{ Receita Residencial } & Perda líquida & Perda (\%) \\
\cline { 2 - 6 } & $\mathbf{A}$ & $\begin{array}{c}\text { B } \\
\text { (antes) }\end{array}$ & $\begin{array}{c}\text { C } \\
\text { (depois) }\end{array}$ & (C-B)=D & RT(D/A) \\
\hline Norte & 120,98 & 51,55 & 48,87 & $(2,67)$ & $-2,21 \%$ \\
\hline Nordeste & 347,10 & 164,31 & 141,56 & $(22,76)$ & $-6,56 \%$ \\
\hline Sudeste & $1.832,23$ & 696,39 & 683,15 & $(13,23)$ & $-0,72 \%$ \\
\hline Sul & 592,12 & 222,33 & 215,61 & $(6,72)$ & $-1,13 \%$ \\
\hline Centro-Oeste & 183,70 & 80,36 & 80,36 & $(3,07)$ & $-1,67 \%$ \\
\hline Total & $3.076,22$ & $1.214,93$ & $1.166,48$ & $(48,45)$ & $-1,58 \%$ \\
\hline
\end{tabular}

Quadro 17 - Resumo da simulação de descontos de baixa renda.

Fonte: elaborado por Campelo et al. (2003)

Em números absolutos, das 64 concessionárias apenas 7 não apresentaram redução na receita ao aplicar os novos critérios da Tarifa Social. A concessionária que apresentou maior perda líquida absoluta, em decorrência do aumento de consumidores com direito a Tarifa Social, foi a COELBA em R $\$ 7,2$ milhões/mês, o que representa $8,39 \%$ sobre a Receita Total da empresa. Acompanhando essa tendência de forte impacto estão as concessionárias que atendem aos Estados de Sergipe, Piauí, Maranhão e Alagoas, que apresentaram os mais altos percentuais de perda sobre a receita total. As 11 concessionárias da região Nordeste acumulam a maior perda líquida, equivalente a $\mathrm{R} \$ 22,7$ milhões/mês (Campelo et al., 2003) o que decorre do grande número de famílias dessa região que são beneficiárias de programas sociais do Governo Federal. 
Como parâmetro da importância e impacto do programa da Tarifa Social devese considerar que o total de recursos federais gastos em programas sociais (excluídos gastos financeiros e com a Previdência Social) corresponde a $R \$ 40,3$ bilhões (Senado Federal, 2001) e o custo para a ISEB da Tarifa Social é de R $\$ 581$ milhões anuais, ou seja $1,44 \%$ desse total. 


\section{DISCUSSÃo}

A Tarifa Social consiste no preço definido pelo agente regulador que será cobrado pelas empresas de distribuição de energia elétrica ao consumidor final da classe residencial que reunir as condições sócio-econômicas definidas na legislação.

Dessa forma, a existência da Tarifa Social representa uma diminuição do faturamento das empresas de distribuição de energia elétrica e uma imposição contrária ao seu objetivo de maximização de lucros, já que a mesma quantidade de energia é fornecida a preços menores.

A evolução da Tarifa Social ao longo do período considerado pode ser compreendida como a evolução de um processo de definição de preços, praticados pela ISEB.

Para que essa compreensão seja possível é necessário supor, e consiste em hipótese fundamental desse estudo, que a Tarifa Social não foi implementada ao longo dos anos somente como um programa governamental de distribuição de renda ou de inclusão social, mas sim como uma forma economicamente eficiente de definição do preço da energia elétrica para os consumidores residenciais, adequada aos contornos institucionais da ISEB em cada período.

Pode ser demonstrado que, no período considerado no âmbito do presente estudo, a forma de concessão dos descontos da Tarifa Social aos consumidores de baixa renda variou em função da evolução da estrutura de mercado da ISEB, conforme Quadro 18. 


\begin{tabular}{|c|c|c|c|c|c|}
\hline & 1974-1985 & 1985-1993 & 1993-1996 & 1996-2001 & 2002 \\
\hline Denominação & Residencial & Residencial & Residencial & $\begin{array}{c}\text { Residencial } \\
\text { Baixa Renda }\end{array}$ & $\begin{array}{c}\text { Residencial Baixa } \\
\text { Renda }\end{array}$ \\
\hline $\begin{array}{l}\text { Universo de } \\
\text { beneficiados }\end{array}$ & $\begin{array}{c}\text { Todos os } \\
\text { consumidores } \\
\text { residenciais }\end{array}$ & $\begin{array}{c}\text { Todos os } \\
\text { consumidores } \\
\text { residenciais }\end{array}$ & $\begin{array}{c}\text { Todos os } \\
\text { consumidores } \\
\text { residenciais }\end{array}$ & $\begin{array}{l}\text { Somente os } \\
\text { consumidores } \\
\text { cadastrados } \\
\text { como "baixa } \\
\text { renda" }\end{array}$ & $\begin{array}{c}\text { Somente os } \\
\text { consumidores } \\
\text { cadastrados como } \\
\text { "baixa renda" }\end{array}$ \\
\hline $\begin{array}{l}\text { Modalidade de } \\
\text { descontos }\end{array}$ & $\begin{array}{l}\text { i) Equalização } \\
\text { tarifária } \\
\text { ii) Descontos } \\
\text { em cascata }\end{array}$ & $\begin{array}{l}\text { i) Equalização } \\
\text { tarifária } \\
\text { ii) Descontos } \\
\text { em cascata }\end{array}$ & $\begin{array}{c}\text { Descontos em } \\
\text { cascata }\end{array}$ & $\begin{array}{c}\text { i) Descontos } \\
\text { para pequenos } \\
\text { consumos sem } \\
\text { "cascata" }\end{array}$ & $\begin{array}{l}\text { i) Descontos para } \\
\text { pequenos consumos } \\
\text { sem "cascata" }\end{array}$ \\
\hline $\begin{array}{l}\text { Critérios para } \\
\text { concessão de } \\
\text { descontos }\end{array}$ & Inexistentes & Inexistentes & Inexistentes & $\begin{array}{c}\text { Critérios de } \\
\text { ordem técnica } \\
\text { (consumo, } \\
\text { carga, etc.) }\end{array}$ & $\begin{array}{l}\text { Cadastramento em } \\
\text { programas sociais }\end{array}$ \\
\hline ISEB & $\begin{array}{c}\text { Forte controle } \\
\text { estatal, com } \\
\text { excesso de } \\
\text { capacidade de } \\
\text { produção }\end{array}$ & $\begin{array}{c}\text { Forte controle } \\
\text { estatal, com } \\
\text { alto } \\
\text { endividamento } \\
\text { das firmas }\end{array}$ & $\begin{array}{l}\text { Processo de } \\
\text { Privatização }\end{array}$ & $\begin{array}{c}\text { Empresas } \\
\text { distribuidoras } \\
\text { privatizadas }\end{array}$ & $\begin{array}{c}\text { Empresas } \\
\text { distribuidoras } \\
\text { privatizadas, com } \\
\text { aumento da } \\
\text { intervenção estatal } \\
\text { (Racionamento) }\end{array}$ \\
\hline
\end{tabular}

Quadro 18 - Evolução da regulamentação da Tarifa Social 1974-2003.

Fonte: resultado da pesquisa.

Para que essa hipótese (fixação de preços economicamente eficiente) seja viável é necessário que se possa concluir que o mercado de energia elétrica não é caracterizado como competitivo, mas como um monopólio, ou seja, que haja poder de mercado suficiente para a fixação de preços em níveis convenientes a determinadas políticas. Como foi demonstrado no presente estudo o mercado de distribuição de energia elétrica possui a estrutura de um monopólio (vide 2.1.3).

A atividade de distribuição de energia elétrica, excluídos os consumidores "livres" conforme definidos na legislação, consiste em um monopólio em sentido estrito já que em determinada área geográfica:

a) há apenas um ofertante de energia elétrica, a própria distribuidora; 
b) há uma grande quantidade de consumidores até mesmo nas áreas de concessão das menores distribuidoras;

c) o bem ofertado (energia elétrica) não possui substitutos próximos, já que dependeria da posse de geradores de energia ou painéis fotovoltaicos em grande parte inviáveis devido ao seu custo de aquisição ou operação.

d) Há barreiras de entrada a novos ofertantes de natureza legal, pois trata-se de atividade que só pode ser exercida com autorização do Estado e que é vinculada a um único contrato de concessão para exploração de determinada área. Além da barreira legal existe a própria barreira tecnológica, dado os elevados custos irrecuperáveis com a infraestrutura necessária.

Avançando nessa análise, em função dos elevados custos médios e dos reduzidos custos marginais de prestação do serviço, característicos da tecnologia empregada, a atividade de distribuição de energia elétrica pode ser considerada um monopólio natural (vide 2.2.1).

Como a política de Tarifa Social é válida para todas as firmas da ISEB, não é adequado concluir-se que essa política de preços decorra de decisões individuais das firmas que compõem essa indústria, visando a maximização de lucros. Entretanto, é possível abstrair o conceito de firma para que toda a ISEB, dados os fins da análise aqui pretendida, possa ser considerada como uma única firma monopolista do serviço de energia elétrica nacional. Nesse contexto as firmas individuais que compõem essa indústria seriam consideradas como meras plantas, que produziriam e venderiam a energia sob intensa coordenação da "firma" que a controla. Apesar dos evidentes limites dessa abstração a mesma é útil para que se possa aprofundar a análise da Tarifa Social, especialmente como uma forma de fixação de preços por um empresa monopolista, nesse caso a própria ISEB.

Desde a consolidação da Eletrobrás e da fase de forte influência estatal a ISEB progrediu rapidamente na integração das atividades de geração, transmissão e distribuição. Sob a crescente influência estatal a integração na operação e no planejamento da expansão do sistema levou ao desenvolvimento do SIN. A integração não se resumiu à coordenação das diversas atividades, mas avançou até uma verdadeira integração da atuação das firmas que as compõem. 
Nesse aspecto avançou a padronização dos sistemas, equipamentos, decisões sobre investimentos na expansão do sistema elétrico. Um dos aspectos que demonstram o grau de integração das firmas na fase de consolidação do modelo estatal foi a equalização tarifária promovida em 1974 e que fez com que as tarifas (preços) finais de energia elétrica fosse igual para todas as firmas e consumidores do país, independentemente do mercado atendido por cada uma das firmas e de sua estrutura de custos.

Essa abstração, visando melhor compreensão do problema em análise, consistente em considerar a ISEB uma única "firma" é coerente quando verificadas algumas de suas principais características. A ISEB desde a fase de propriedade estatal das firmas a tecnologia de produção e organização da atividade técnica de produção e distribuição de energia utilizou um modelo em que apesar da existência de dezenas de firmas de geração, transmissão e distribuição inexistisse a capacidade individual de decisão sobre produto e preço. Essa característica permite que toda a indústria seja analisada, sem perda de precisão, como uma única firma (controlada pelo Governo, através de suas estatais) ofertante de energia elétrica, ou seja, como uma única empresa de fornecimento de energia elétrica monopolista, integrada verticalmente.

A operação coordenada da geração hidráulica na ISEB implica que a firma que detém a planta de produção não possui capacidade de decisão sobre a quantidade da energia a ser produzida. Essa característica dificulta que o agente privado invista nesses sistemas (Abreu, 1999), pois necessariamente deverá integrar-se a um sistema cooperativo, que, muitas vezes, imporá decisões que sejam incompatíveis com seu objetivo de maximização do lucro.

A atividade econômica de geração e fornecimento de energia é diferenciada de outros ramos da atividade econômica devido às características do produto e da tecnologia existente que implicam em:

a) impossibilidade de armazenamento da produção excedente;

b) consumo instantâneo da produção;

c) impossibilidade de produção em níveis inferiores ao demandado (atendimento pleno da demanda) 
Tais características, ao lado da coordenação na produção, implicam no fato de que a firma praticamente não detém qualquer forma de controle sobre a quantidade de sua produção. No setor de energia elétrica o volume de produção em cada instante depende, em última análise, da decisão do consumidor de consumi-la.

Ao acionar equipamentos elétricos os consumidores aumentam a demanda de energia que flui no sistema ao que está conectado, o que faz com que à medida que essa demanda aumente as usinas que já estão gerando energia sejam levadas a aumentar a sua produção. À medida em que essa demanda aumenta, e as usinas atingem o máximo de sua capacidade de geração, o ONS "despacha" em tempo real a ordem para que novas usinas entrem em operação. Esse processo ocorre de forma inversa à medida em que a demanda diminui, ao menos duas vezes ao dia, de forma mais evidente nos chamados "horários de ponta" da manhã e da noite quando o consumo atinge o nível máximo.

A irregular distribuição da carga ao longo do dia, e mesmo ao longo de diferentes meses, faz com que existam "picos de demanda" que devem ser supridos, se necessário com a operação simultânea de todas as usinas de geração disponíveis. Essa característica faz com que, por longos períodos, o produtor seja obrigado a manter sua firma sem produção, independentemente de sua decisão, já que a geração nesse período, dada a impossibilidade de formação de estoques, representaria apenas desperdício de insumos (capacidade do reservatório, gás ou carvão) e sobrecarga dos sistemas de transmissão e distribuição.

Nas decisões que envolvem o "despacho" (ordem para início da produção) das plantas de geração hidráulica são considerados os aspectos da bacia hidrológica em que se situam, pois, ao produzir energia, uma hidrelétrica verte água que seguirá para o reservatório de outra planta, que pode, inclusive, pertencer a outra firma. A planta situada a jusante, e que recebe esse fluxo de água, pode armazená-la até certa capacidade (a do seu reservatório). Alcançado o nível máximo a firma a jusante deve descarregar seu reservatório, seja gerando energia através de suas turbinas ou vertendo a água por seus escoadouros. A primeira hipótese (geração) só é viável, em termos de eficiência do sistema, se houver demanda instantânea para tanto. A segunda hipótese (verter água pelos escoadouros) representa o desperdício de energia potencial para geração de energia. Tais características demandam, para uma operação eficiente do SIN, uma intensa atividade de coordenação da produção das 
plantas de geração, o que representa a perda da capacidade de decisão sobre o nível do produto de cada uma firmas.

A integração de uma nova usina ao sistema cooperado implica em uma diminuição na participação do resultado de praticamente todos os geradores daquele sistema, com reflexos sobre seu faturamento (Abreu, 1999). A menos que ocorra um correspondente reajuste das tarifas, ou um aumento correspondente da demanda, a cada novo empreendimento aumenta-se a incerteza a que a firma está exposta.

A racionalidade dessa forte integração da ISEB pode ser compreendida como uma forma de otimização do desempenho do setor que se assemelha ao modelo do monopolista detentor de várias fábricas, ou seja, as usinas de propriedade das firmas integradas ao SIN.

Segundo esse modelo teórico, em certas circunstâncias, pode ser desejável a um monopolista ter mais do que uma fábrica ou planta. Em geral, a produção em várias fábricas aumenta os lucros do monopolista se a média ponderada dos custos médios de longo prazo para as várias fábricas ao nível de produção do momento for inferior ao custo médio de longo prazo $\left(\mathrm{CMe}_{\mathrm{LP}}\right)$ ao mesmo nível de produção produzido por uma única fábrica. Se esta condição se verificar, e se os custos de transporte dos diversos centros de produção para os centros de consumo não forem elevados, então, a empresa deverá ter mais do que uma fábrica.

Considerando a hipótese de apenas 2 fábricas, com RT $\left(\mathrm{y}_{1}+\mathrm{y}_{2}\right)$ a função receita total, e $\mathrm{CT}_{1}\left(\mathrm{y}_{1}\right)$ e $\mathrm{CT}_{2}\left(\mathrm{y}_{2}\right)$ as funções de custo das duas fábricas, as condições de maximização do lucro são:

$$
\begin{aligned}
& p=p(q)=p\left(q_{1}+q_{2}\right) \\
& q \equiv q_{1}+q_{2}
\end{aligned}
$$

Onde:

$$
\begin{aligned}
& q=\text { produção total } \\
& q_{1}=\text { produção da fábrica } 1 \\
& q_{2}=\text { produção da fábrica } 2
\end{aligned}
$$


Receita da firma:

$$
\begin{aligned}
& R T\left(q_{1}, q_{2}\right)=p\left(q_{1}+q_{2}\right) \times p\left(q_{1}+q_{2}\right) \\
& =p(q)(q)=R T(q)=R T\left(q_{1}+q_{2}\right)
\end{aligned}
$$

Lucro da firma:

$$
\begin{gathered}
\Pi \quad\left(q_{1}, q_{2}\right) \quad \equiv R T\left(q_{1}, q_{2}\right)-C T_{1}\left(q_{1}\right)-C T_{2}\left(q_{2}\right) \\
=R T\left(q_{1}+q_{2}\right)-C T_{1}\left(q_{1}\right)-C T_{2}\left(q_{2}\right)
\end{gathered}
$$

Problema do monopolista:

$$
\left(q_{1}^{M}, q_{2}^{M}\right)=\max _{q 1, q 2} \Pi\left(q_{1}, q_{2}\right)
$$

Condição marginal de primeira ordem:

$$
\begin{aligned}
& \frac{\partial \Pi\left(q_{1}^{M}, q_{2}^{M}\right)}{\partial q_{1}}=\frac{\partial R T\left(q_{1}^{M}, q_{2}^{M}\right)}{\partial q_{1}}-\frac{\partial C T_{1}\left(q_{1}^{M}\right)}{\partial q_{1}} \\
& =\frac{\partial R T\left(q_{1}^{M}+q_{2}^{M}\right)}{\partial q}-\frac{\partial C T_{1}\left(q_{1}^{M}\right)}{\partial q_{1}}=0 \\
& \frac{\partial \Pi\left(q_{1}^{M}, q_{2}^{M}\right)}{\partial q_{2}}=\frac{\partial R T\left(q_{1}^{M}, q_{2}^{M}\right)}{\partial q_{2}}-\frac{\partial C T_{2}\left(q_{2}^{M}\right)}{\partial q_{2}} \\
& \frac{\partial R T\left(q_{1}^{M}+q_{2}^{M}\right)}{\partial q}-\frac{\partial C T_{2}\left(q_{2}^{M}\right)}{\partial q_{2}}=0
\end{aligned}
$$

Segue das condições marginais que

$$
\frac{\partial R T\left(q_{1}^{M}+q_{2}^{M}\right)}{\partial Q}=\frac{\partial C T_{1}\left(q_{1}^{M}\right)}{\partial q_{1}}=\frac{\partial C T_{2}\left(q_{2}^{M}\right)}{\partial q_{2}}
$$

O custo marginal em cada fábrica deverá ter inclinação superior à da receita marginal. Para um monopolista que vende um bem homogêneo e produz em múltiplas fábricas, o equilíbrio corresponde a distribuir a produção pelas fábricas até se igualarem os custos marginais entre si e estes à receita marginal. Esta é uma condição necessária, mas não suficiente para maximização de lucro pois além disso, é preciso que o custo marginal iguale a receita marginal. 
Como já referido, a operação do SIN levou o órgão responsável por tal gestão (atualmente o ONS) a comportar-se como um monopolista detentor de diversas plantas, que na hipótese real pertencem a firmas diferentes, otimizando o "despacho" tanto tecnicamente (capacidade instantânea de geração de cada planta) quanto economicamente (ao determinar a operação das plantas com menor custo marginal de produção).

Conforme exposto (vide 2.2.1) a literatura indica que uma das principais razões para que uma indústria seja considerada um monopólio natural é a existência de economias de escala em toda a faixa relevante de produção, ou seja, a escala mínima eficiente de operação é adequada para o atendimento de toda a demanda. Ao se considerar a ISEB como uma única firma, dado o intenso grau de integração e coordenação de todos os fatores produtivos, fica evidente que o requisito de escala mínima eficiente é alcançado, pois toda a demanda do mercado é atingida. Mesmo ao se considerar somente as concessionárias de distribuição de energia elétrica e seus mercados cativos, existem razões suficientes para indicar a ocorrência de economias de escala.

Nessa indústria verifica-se que quase a totalidade dos bens de produção utilizados na prestação dos serviços reúne as características de bens discretos (tais como represas, turbinas, linhas de transmissão e distribuição) e de subutilização (em decorrência da impossibilidade física de manutenção de estoques de energia o que faz necessário que a capacidade de produção seja sempre igual ou maior que a demanda projetada e incerta no futuro, a ocorrência dos "picos de demanda" e devido ao longo período de maturação dos investimentos em tais bens de capital). Essa característica tecnológica pode propiciar ganhos de escala associados à indivisibilidade técnica dos ativos. A característica de sistema interligado da ISEB, especialmente em sua fase estatal, quando a Eletrobrás atuava como holding das empresas do setor, era uma fonte de economias de escala relacionada à lei dos grandes números.

Ganhos de escala decorrentes da operação multi-planta decorrem da existência de grandes redes de linhas de transmissão que garantem também, na hipótese de falha em uma das concessionárias geradoras, a continuidade do fornecimento de energia elétrica através do aumento de produção nas demais geradoras, visando suprir a demanda instantânea do mercado. Essa possibilidade técnica de operação da indústria permite a diminuição de custos com a manutenção 
de capacidade de reserva em cada unidade, ao mesmo tempo em que garante maior confiabilidade e segurança ao sistema.

O ganho de especialização das plantas, gerando ganhos de escala, pode ser representado pela coexistência de usinas hidrelétricas e termelétricas operando em rede, com "despacho" centralizado, que busca garantir, ao longo do ano, a produção ao menor custo (Looty \& Szapiro, 2002). No "período úmido", quando os reservatórios das usinas hidrelétricas estão em capacidade plena as termelétricas permanecem sem produção, eliminando o custo de geração mais elevado dessa tecnologia, em função do custo do combustível fóssil. Inversamente, no "período seco" quando é necessário diminuir a produção das hidrelétricas sob pena de esvaziamento dos reservatórios (cujo colapso representaria um custo econômico muito elevado) as termelétricas iniciam sua produção de energia a um custo inferior ao custo de oportunidade de geração hidrelétrica. Outra fonte de economia de escala relacionada ao ganho de especialização das plantas, considerada a operação interligada, é a possibilidade de construção de hidrelétricas distantes dos maiores centros consumidores, porém onde são encontrados os maiores potenciais hidráulicos. As termelétricas podem ser construídas próximas de centros urbanos, onde o acesso aos combustíveis (gás, óleo, carvão e até mesmo urânio) é facilitado pela infra-estrutura existente, bem como pelo tamanho relativamente pequeno dessas centrais de geração elétrica.

Ganhos de escala associados à possibilidade de flexibilização da operação são verificados no SIN no atendimento de flutuações de demanda diárias ou mensais, através do deslocamento da produção para plantas com diferentes tecnologias. Apesar de gerar energia com um custo marginal mais elevado, as usinas termelétricas podem ser construídas a preços muito inferiores e em prazos muito menores, podendo representar uma fonte de economia na medida em que podem ser utilizadas durante 0 período de ponta suprindo o excesso de demanda, sem que as caras usinas hidroelétricas tenham que ser superdimensionadas para atender a esses picos de demanda.

Deve ser considerado que ao longo do tempo os custos de transporte da energia elétrica (transmissão) devem aumentar, atuando como uma deseconomia de escala, em decorrência do progressivo esgotamento de potenciais hidráulicos próximos aos principais centros consumidores. 
Na presença de economias de escala tão relevantes, é adequado considerar que a estrutura do mercado de energia elétrica seja considerado como monopólio natural. Porém, foi demonstrado (Pineau, 2003) que na atividade de geração de eletricidade há uma relação inversa entre o custo marginal de geração de energia elétrica e o investimento inicial na construção das plantas de geração, ou seja, quanto maior o investimento inicial (portanto, o custo médio de geração), menor o custo marginal de geração. Nesse estudo foram comparadas usinas de geração norteamericanas com bases tecnológicas diferenciadas quanto ao combustível ser nuclear, carvão ou gás.

Foi possível identificar nesse estudo que cada planta possui uma estrutura de custos característica que não é relacionada com seu tamanho, afastando a hipótese de ganhos de escala decorrentes diretamente do tamanho da planta, hipótese que frequentemente é apresentada para justificar a construção de grandes usinas, especialmente hidroelétricas e nucleares. A relação que foi observada naquele estudo indica que níveis baixos de investimento inicial implicam em altos custos de operação (como usinas a gás, mesmo consideradas as mais modernas tecnologias) e que plantas com altos níveis de investimento inicial apresentam custos de operação baixos (custo marginal), como as usinas nucleares e as usinas hidroelétricas.

Como já referido, o SIN tem sua operação técnica fundamentada no atendimento da demanda existente instantânea, estando fora da esfera decisória das firmas a determinação do nível de produto, que é definido pelo consumidor. Por outro lado, a característica de ser um sistema interligado quase nacionalmente e de ausência de estoques, faz com que não seja possível a produção de energia elétrica em níveis inferiores ao demandado pelo mercado.

Por razões técnicas a hipótese de produção de energia em nível inferior ao total demandado levararia a um colapso do sistema, através do desligamento automático dos sistemas em funcionamento, devido à operação em sobrecarga, implicando no desabastecimento instantâneo de todo o mercado (blecaute), que, dada a natureza interligada do sistema, pode afetar quase a totalidade do território nacional.

Por outro lado, decisões de produção, por parte das firmas ou do agente coordenador da operação do sistema, em níveis superiores ao da demanda instantânea seriam ineficientes dada a característica do produto (que não permite estocagem) e ao desperdício de fatores de produção (água armazenada em 
reservatórios ou combustível de termelétricas). Essa característica técnica do setor (atendimento pleno da demanda instantânea) faz com que a ISEB atue em um nível que não é o maximizador dos lucros, mas sim em um nível que maximize sua capacidade de produção dada a demanda existente ou projetada, permitindo caracterizar a ISEB como uma indústria que atua em regime de monopólio natural maximizador de quantidade.

Os limites dessa abstração, que permite a caracterização da ISEB como uma indústria em regime de monopólio natural em escala nacional sob comando direto ou indireto Estado, integrado verticalmente, detentor de várias fábricas e maximizador de quantidade, realizada anteriormente encontra limitações como já referido. Essa caracterização somente é válida, no âmbito do presente estudo, como uma ferramenta de análise útil para melhor compreensão da implementação da Tarifa Social, que é o objeto central desse estudo. As características dessa industria que fundamentava essa aproximação analítica decorriam da intensa coordenação e integração das atividades de geração, transmissão e a distribuição de energia elétrica na produção de uma mercadoria que não pode ser armazenada, a baixo custo marginal, suficiente para atendimento à toda demanda e que deve ser consumida no momento em que é gerada. A eficiência, a confiabilidade e a qualidade do serviço, dada a estrutura da ISEB, pressupõe a existência de coordenação na operação do sistema elétrico.

Mesmo que a caracterização da ISEB como uma única firma monopolista encontre limitações, a identificação como monopólio natural das firmas de distribuição de energia elétrica na sua área de concessão é direta, pois essa estrutura de mercado corresponde diretamente ao modelo predito na literatura (vide 2.2). Mesmo que essa caracterização seja adequada, o comportamento das firmas apresenta um desvio do comportamento previsto nos modelos de maximização do lucro na Teoria do Monopólio devido à intensa regulação estatal de sua atuação, o que inviabiliza o comportamento maximizador de lucro, através do controle da produção e do preço.

Esse desvio do comportamento da firma monopolista das predições do modelo decorre de três fatores:

a) os preços (tarifas) não são determinados pelo ofertante monopolista, seja a ISEB como um todo, seja a distribuidora em sua área de concessão, mas fixados exogenamente pelo agente regulador, 
b) a quantidade a ser ofertada é determinada não pela decisão da firma, mas sim pela demanda instantânea dos consumidores;

c) a demanda de mercado deve ser atendida integralmente quanto ao nível de produto, sob pena de colapso do sistema, maximizando-se a produção.

Essa última característica, especialmente, decorre do modelo técnico adotado pela ISEB, que possui duas características técnicas atípicas em relação aos demais modelos de atuação do setor elétrico aplicados em outros países:

a) ampla base de geração hidráulica, com diferentes firmas operando nas mesmas bacias hidrológicas;

b) sistema de transmissão interligado em nível nacional, com utilização de extensas linhas de transmissão em alta e extra-alta tensão, que interligam aproximadamente $90 \%$ do território nacional.

Caso o comportamento das firmas da ISEB coincidisse com o do monopolista descrito na literatura, seria possível utilizar a sua capacidade de influenciar o preço de mercado, escolhendo o nível de preço e de produção que maximizasse seus lucros totais (Varian, 1999), ou seja, para o monopolista do modelo teórico o preço e a receita marginal são variáveis endógenas, determinados por sua escolha de produção (Eaton \& Eaton, 1999). Entretanto, as firmas que integram a ISEB não possuem controle sobre a quantidade a ser produzida, que é determinada pela demanda instantânea e pelo despacho centralizado e sobre o preço (tarifa), que é fixado exogenamente pelo agente regulador.

Considerando-se todas as classes de faturamento da ISEB, existem 50 subclasses de faturamento, sendo que a cada uma dessas subclasses é definido um diferente preço (tarifa) para cada unidade de energia fornecida. As cinqüenta subclasses envolvem apenas os preços que podem ser praticados em relação aos usuários finais, não sendo considerados os preços de geração e transmissão de energia elétrica cobrados, segundo valores definidos pelo ente regulador, pelas concessionárias de geração e transmissão de energia elétrica.

Dado que existem atualmente 64 concessionárias de distribuição de energia elétrica, que praticam 50 preços diferentes para a mesma unidade de energia segundo o critério de faturamento definido na legislação (vide 2.4.2), pode-se chegar a um total de 3.200 diferentes preços finais para a mesma unidade de energia elétrica em todo 
território nacional, desconsideradas as diferentes alíquotas tributárias em cada unidade federativa e a variação dos encargos setorias entre as classes de consumo que implicariam numa maior variedade de preços finais. No presente estudo não se pretendeu uma análise quantitativa dos 3.200 diferentes preços que podem ser praticados, para o mesmo bem (unidade de energia), mas uma análise da prática de discriminação de preços praticado pela ISEB, que é admitida como uma estrutura de mercado em monopólio natural.

A análise da política de Tarifa Social sob a ótica da Teoria do Monopólio permite identificar que todas as diferentes configurações adotadas desde 1985 representam políticas de fixação de preços consistentes com uma situação de monopólio da ISEB, seja diretamente através da Eletrobrás S/A durante o período estatal, seja indiretamente através da regulamentação das políticas tarifárias das empresas privatizadas, pelo DNAEE e ANEEL sucessivamente, durante o período privado.

A política de equalização tarifária e de reajustes inferiores à taxa de inflação instituída a partir de 1974 possuía conotação social especialmente para os usuários de baixa renda situados em localidades isoladas, que passaram a contar com a possibilidade de acesso físico à rede pública de distribuição em decorrência de sua expansão a diversas localidades onde era inexistente, com a cobrança de uma tarifa que não incorporava esses custos de fornecimento. Mesmo os consumidores situados fora dessas regiões eram beneficiados por tarifas escalonadas (descontos maiores para os menores consumos) reajustadas em um nível inferior ao da inflação. O preço da energia elétrica ao segmento residencial recebia "descontos em cascata" no qual a quantidade total consumida era dividida em blocos de consumo, sendo cada parte cobrada segundo a tarifa estabelecida para aquele bloco, sendo a tarifa crescente para blocos de consumo maiores. Esse escalonamento tarifário para as primeiras faixas de consumo, favorecendo de forma indiscriminada todos os consumidores, independentemente de seu poder aquisitivo mas somente de seu consumo, persistiu sendo praticado até 1996 a todos os consumidores residenciais e ainda hoje é aplicado à Subclasse Residencial Baixa Renda

Verifica-se, que a política de Tarifa Social praticada entre 1985 e 1993 consistia em um mecanismo de descriminação de preços de segunda ordem (vide 2.2.3.2), ao definir diferentes tarifas para diferentes blocos de consumo, porém com a cobrança de 
tarifas menores para os primeiros blocos de consumo e não as mais elevadas, como seria esperado em uma estratégia de maximização de lucro, conforme definido por esse modelo na literatura.

Diferentemente da política aplicada aos usuários do seguimento industrial, onde a tarifa diminui à medida em que o consumo aumenta, o que é consistente com o objetivo de maximização do lucro através da discriminação de preços de $2^{\mathrm{a}}$ ordem descrita na literatura, a Tarifa Social tendia a aumentar conforme o consumo.

A racionalidade desse esquema tarifário, que é inverso ao comportamento de maximização do lucro do monopolista descrito na literatura, sem que sejam considerados benefícios sociais supostamente objetivados, pode ser identificada como uma forma de auto-seleção (Varian, 1999) entre os usuários do setor residencial. Ao contrário da discriminação de preços perfeita (discriminação de primeiro grau) nessa hipótese (discriminação de preços de segunda ordem) o monopolista não possui conhecimento pleno da propensão a pagar e a discriminação entre consumidores pode ser inviável, especialmente quando se considera os milhões de consumidores residenciais atendidos pela ISEB. A auto-seleção dos consumidores, ou seja, um esquema de preço-quantidade cuidadosamente definidos pelo monopolista, pode induzir aos consumidores a revelarem sua propensão a pagar optando pelo esquema adequado.

O esquema de auto-seleção representado pelo aumento progressivo da tarifa em relação ao maior consumo permitiria diferenciar entre os consumidores de baixa e alta renda, dada a pressuposição de que os consumidores de alta renda estariam menos dispostos a alterar seus hábitos de consumo para manter baixo seu nível total de consumo e, assim, gozar de tarifas menores. Por outro lado, é adequado pressupor que os consumidores de baixa renda, estariam dispostos a alterar seu perfil de consumo, tanto para ser beneficiado por maiores níveis de descontos sobre a tarifa básica, como para manter seu gasto total baixo.

Além de funcionar como mecanismo de auto-seleção dos consumidores, esse esquema tarifário, em um contexto de excesso de capacidade de geração, permitia ampliar a base de usuários (consumidores), inclusive com reflexos positivos na diminuição do número de ligações clandestinas, especialmente em grandes centros urbanos. 
A cobrança de tarifas elevadas dos maiores consumos era utilizada como forma de compensar a perda de faturamento referente aos descontos nos primeiros blocos de consumo, remunerando a empresa com uma "tarifa média" proporcional ao montante consumido, por cada perfil de consumidor, que garantia o seu equilíbrio financeiro (Bitu, 1985).

A distinção de usuários residenciais em diferentes classes tarifárias baseia-se na hipótese de que consumidores de baixa renda e de alta renda têm demandas distintas e que é possível definir-se critérios para separá-las, como por exemplo o critério de potência instalada, adotada pela maioria das concessionárias a partir de 1996 e que supostamente seria eficiente para indicar a renda dos usuários em função da posse de equipamentos eletrodomésticos.

Pode-se, portanto, identificar que as diferentes políticas referentes à Tarifa Social são consistentes com os modelos de discriminação de preços pelo monopolista na forma de discriminação de preços $2^{\circ}$ grau, com tarifação diferenciada de blocos de consumo no período 1985-1995.

A alteração da Tarifa Social implementada a partir de 1995, com a criação da "Subclasse Residencial Baixa Renda", teve o objetivo de permitir que as empresas distribuidoras concedessem os descontos do escalonamento tarifário (Tarifa Social) somente a uma parcela do universo então beneficiado.

Isso foi possível através da criação de uma subclasse para faturamento dos consumidores residenciais de menor poder aquisitivo conforme as antigas regras de escalonamento tarifário, enquanto os demais passariam a ser classificados na subclasse residencial, passando a pagar a tarifa residencial de forma intergral.

No processo de preparação para a privatização das distribuidoras (vide 4.1.3), três movimentos se distinguem, tendentes a reduzir os benefícios referentes à Tarifa Social, resultando em aumento de receita das distribuidoras e de seu valor no processo de privatização:

a) mudança dos critérios de enquadramento dos beneficiários de tarifas sociais, incluindo a redução do limite superior para descontos;

b) remoção da não-progressividade na concessão dos descontos, para consumos superiores ao limite de desconto (fim do desconto "em cascata"); 
c) a redução do percentual de desconto incidente sobre a tarifa residencial.

Essas alterações foram implementadas pela Portaria DNAEE 437/95, que alterou a forma de cálculo dos descontos da Tarifa Social e implementou um modelo de discriminação dos consumidores de "baixa renda" que continuariam a receber os descontos.

A criação da "Subclasse Residencial Baixa Renda" em 1995 representou um refinamento da política tarifária então implementada, passando a ser uma forma de fixação de preços consistente com um mecanismo de discriminação de preços de terceiro grau descrito na literatura, pois criou uma segmentação do mercado consumidor em dois sub-mercados (pelos mais diversos critérios, aplicados em cada distribuidora) com a cobrança de um preço e cada sub-mercado.

A criação de um mecanismo de barreira formal (preenchimento de requisitos que devem ser comprovados documentalmente junto à distribuidora) representa um mecanismo de auto-seleção dos consumidores, em que a divisão da demanda em dois sub-mercados é feita de forma mais eficiente do que aquela presumida do nível de consumo mensal, vigente até 1995.

A definição dos requisitos que permitiriam a classificação da demanda dos consumidores em dois sub-mercados foi deixada a cargo das próprias empresas distribuidoras. Esse episódio de "liberdade regulatória" apresentou em sua maioria resultados previsíveis, sendo constatadas ampla variação de critérios e resultados da aplicação dos critérios, consistentes com o comportamento de maximização de lucros das firmas.

Particularmente verificou-se que as concessionárias de distribuição que atendiam regiões de fraca atividade industrial e comercial onde, portanto, a receita obtida do setor residencial era muito relevante para o resultado da firma, foram definidos requisitos para a concessão dos descontos muito mais restritivas, de forma que fosse minimizada a perda de receita com a concessão dos descontos da Tarifa Social. Os critérios de segmentação da demanda residencial de baixa renda em empresas em que a receita oriunda do segmento residencial não é tão importante foram mais complacentes, permitindo a concessão dos descontos a um maior universo de beneficiários. 
Os resultados "surpreendentes" de aplicação da Tarifa Social apurados pela ANEEL, sucessora do DNAEE, em 1999 (vide 4.1.4) decorrem diretamente dessa omissão regulatória que deixou sob a esfera decisória das firmas a fixação do nível de descontos a serem concedidos sobre seu faturamento do segmento residencial, o que implicou em diversos casos na fixação, em alguns casos, de critérios extremamente excludentes como forma de maximização do lucro.

A efetividade da aplicação da Tarifa Social, nos moldes pretendidos em 1985, foi reduzida pela definição da nova política tarifária implementada para a população de baixa renda, ao longo da década de 1990, o que representou um aumento do custo da energia elétrica na cesta de consumo das famílias, especialmente as de baixa renda.

\begin{tabular}{|l|c|c|c|c|c|c|c|c|c|c|}
\cline { 2 - 11 } \multicolumn{1}{c|}{} & \multicolumn{8}{c|}{ Classe de rendimento mensal - salário mínimo } \\
\cline { 2 - 11 } \multicolumn{1}{c|}{} & Até 2 & $\mathbf{2}$ a 3 & $\mathbf{3}$ a 5 & $\mathbf{5}$ a $\mathbf{6}$ & $\mathbf{6}$ a 8 & $\mathbf{8}$ a $\mathbf{1 0}$ & $\mathbf{1 0}$ a 15 & $\mathbf{1 5}$ a $\mathbf{2 0}$ & $\mathbf{2 0}$ a 30 & > 30 \\
\hline $\begin{array}{l}\mathbf{1 9 8 7} \\
\mathbf{( \% )} \text { renda }\end{array}$ & 3,24 & 2,26 & 1,97 & 1,61 & 1,56 & 1,60 & 1,37 & 1,38 & 1,22 & 1,34 \\
\hline $\begin{array}{l}\mathbf{1 9 9 6} \\
\mathbf{( \% )} \text { renda }\end{array}$ & 1,60 & 4,23 & 3,10 & 2,57 & 2,07 & 2,17 & 2,10 & 2,07 & 1,97 & 1,84 \\
\hline
\end{tabular}

Quadro 19 - Gastos com energia elétrica.

Fonte: elaborado por Sauer (2002)

Por outro lado os dados disponibilizados pelo MME no "Balanço Energético Nacional - 2002" indicam que os preços médios de energia elétrica no período 19862001 apresentaram sensível redução, tanto para os setores industrial como residencial, sendo que a redução nesse último constata-se que os preços praticados em 2001 correspondem a 45\% dos preços praticados em 1986 (Câmara dos Deputados, 2003) . 


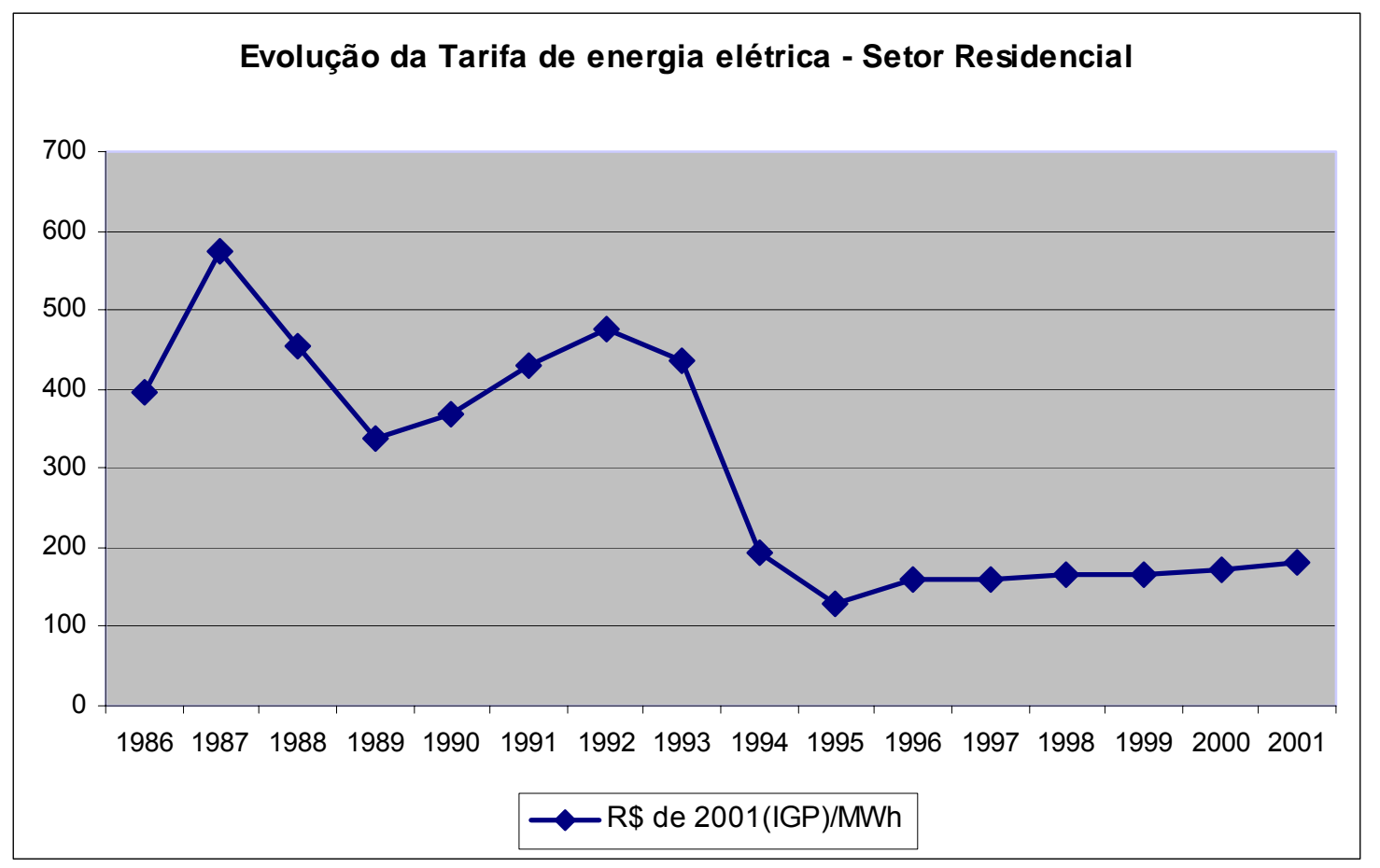

Figura 15 - Evolução da tarifa de energia elétrica média: setor residencial.

Fonte: adaptado de Câmara dos Deputados (2003)

A divergência entre esses dois estudos (aumento do custo da energia elétrica em relação à renda e diminuição do preço da energia elétrica) pode decorrer da utilização de diferentes índices de atualização de valores monetários, bem como do primeiro estudo utilizar o fator renda, o que indicaria que o aumento do custo da energia elétrica para as famílias (Sauer, 2002) decorreria não do aumento de seu preço médio, mas da redução da renda média das famílias no período.

Esse mesmo estudo (Câmara dos Deputados, 2003) aponta que as tarifas de energia elétrica da classe residencial além de diminuírem em termos reais desde 1986, estariam em um patamar médio em termos internacionais, conforme Figura 16. Porém, se dessa mesma amostra, forem tomados apenas os países em desenvolvimento, a tarifa residencial de energia elétrica brasileira apresenta-se como a mais elevada (Figura 17). 


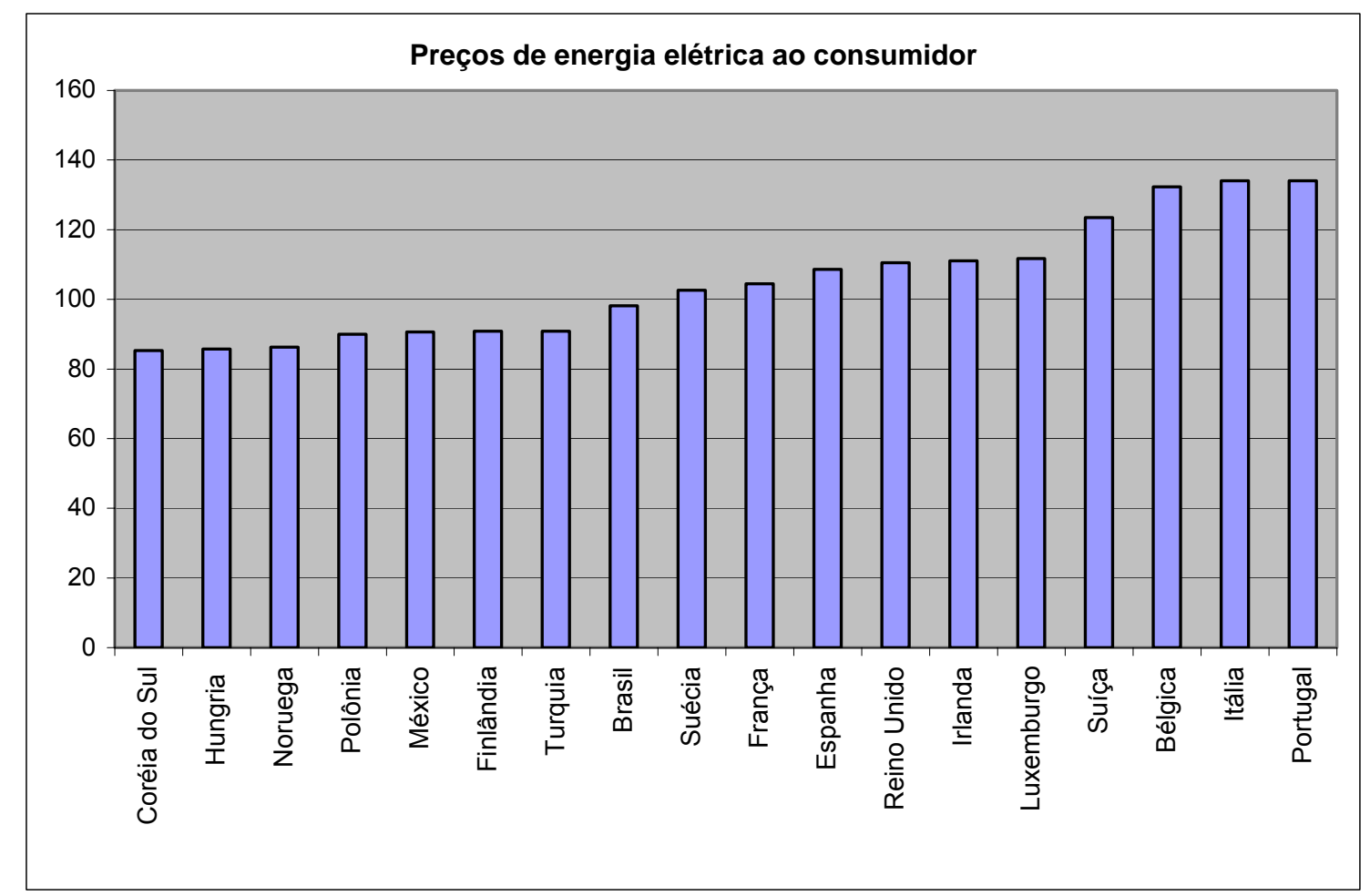

Figura 16 - Preços internacionais de energia elétrica - setor residencial.

Fonte: adaptado de Câmara dos Deputados (2003)

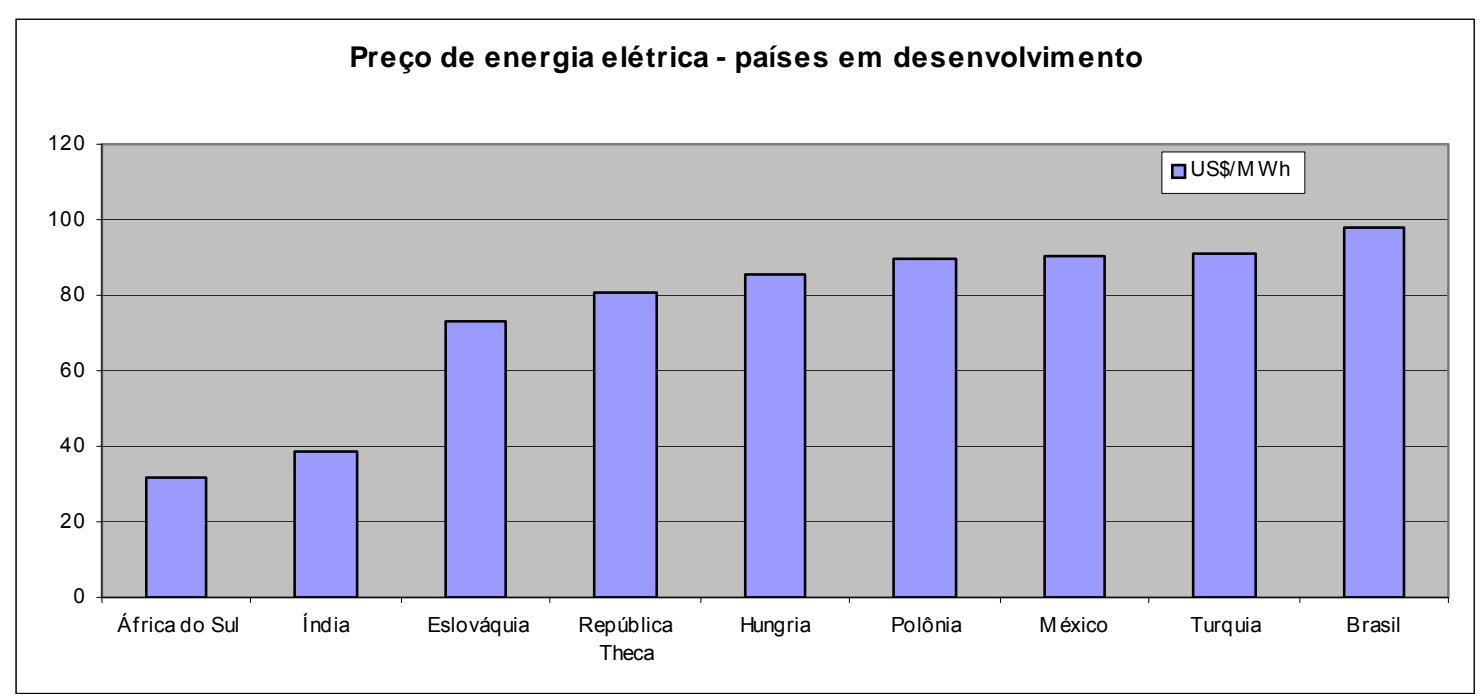

Figura 17 - Preços da energia elétrica em países em desenvolvimento - classe residencial.

Fonte: adaptado de Câmara dos Deputados (2003) 
Os mesmos dados demonstram que caso sejam considerados apenas os países cuja principal fonte de energia é a hidráulica o preço da energia elétrica ao setor residencial brasileira é elevado, o que torna a questão da Tarifa Social ainda mais relevante. Os preços finais da energia elétrica aos consumidores residenciais nesses países, ou seja, Canadá (US\$ 60,10), Brasil (US\$ 98,20) e Suécia (US\$ $102,60)$ demonstram que a tarifa residencial brasileira é bastante elevada em termos comparativos internacionais, especialmente ao se considerar que essa forma de geração de energia é a mais barata e o contexto sócio-econômico em que a renda média do consumidor brasileiro é muito inferior à renda média do consumidor canadense e sueco. Um fator relevante para explicar o elevado preço da energia elétrica no Brasil é a elevada carga tributária incidente sobre o consumo atingindo em média $50 \%$ do preço final, enquanto no Canadá essa carga tributária não passa de $15 \%$.

A política de Tarifa Social implementada a partir de 2002, com a instituição de um modelo de segmentação em dois mercados buscou um aperfeiçoamento do "modelo de barreira", representada pela necessidade de inscrição no Cadastramento Único para Programas Sociais do Governo Federal para recebimento dos descontos.

A iniciativa do agente regulador na ISEB de implementação de uma Tarifa Social, com objetivo de conceder benefícios às famílias de baixa renda, não pode se limitar a estabelecer uma política tarifária favorável, ou seja, a preços tão baixos que as famílias de menor renda possam pagar por ela. Isso porque, por menor que seja a tarifa, muitas das família mais pobres não poderá se beneficiar do fornecimento de energia elétrica simplesmente por não disporem de acesso físico à rede. Atualmente 2,5 milhões de domicílios não têm acesso à energia elétrica (MME, 2003) não se beneficiando da Tarifa Social existente, sendo que a maioria de tais famílias são de baixíssima renda, em sua maioria situados na zona rural da Região Nordeste, cujo chefe de família tem poucos anos de estudo, reside em habitações rudimentares, com poucos cômodos e muitos residentes.

Existem iniciativas governamentais recentes buscando minimizar o problema da exclusão elétrica, onde são utilizados recursos do Tesouro Nacional e das empresas estatais da ISEB. Tais investimentos para atender domicílios e comunidades isoladas, em sua maioria de baixa renda que não interessam comercialmente às firmas privatizadas da ISEB tendo em vista o baixo retorno financeiro e o elevado nível 
de investimento inicial, porém podem apresentar externalidades mais relevantes do que a mera concessão de descontos sobre a fatura mensal.

\subsection{A experiência internacional: Tarifa Social na Ucrânia}

A política tarifária de energia elétrica implementada no setor elétrico ucraniano, diverge daquele utilizado na ISEB, pois naquele a tarifação residencial discrimina entre residências com fornos elétricos e residências com fornos a gás (Vakhitova, 1998). O sistema brasileiro discrimina em função da renda familiar presumida, em função do consumo mensal e outro critérios como o de potência de equipamentos. Naquele sistema tarifário as residências cujas demandas por eletricidade são mais elásticas, ou seja residências dotadas de fornos a gás, devem suportar tarifas mais elevadas. A autoridade regulatória ucraniana justifica essa forma de tarifação inversa ao que prevêem os modelos teóricos com base em razões "sociais".

Aquele modelo tem como fundamento o pressuposto de que os consumidores residenciais não devem ser penalizados pelo uso de fornos elétricos, através de um preço de energia, ou conta de consumo mensal, mais elevados. Tal pressuposto tem como fundamento considerações sobre o impacto social dos elevados custos de substituição desses fornos elétricos por equivalentes a gás e as externalidades positivas do uso da eletricidade, ao menos por parte da população, pois do ponto de vista social os fornos elétricos seriam desejáveis pois:

a) fornos elétricos são mais seguros, pois tem menor possibilidade de gerar incêndios,

b) as redes de fornecimento de gás nem sempre estão disponíveis, especialmente em locais montanhosos ou alagadiços, onde o custo de instalação desse tipo de rede seria proibitivo,

c) em alguns prédios residenciais é proibida a instalação e uso de gás por razões técnicas ou de segurança.

O objetivo final dessa política tarifária é que os gastos com energia elétrica em uma residência com o fogão a gás sejam iguais aos gastos com energia elétrica numa residência que possui um fogão elétrico. Para essa política tarifária atingir seu objetivos os preços relativos devem satisfazer os requisitos de eficiência e equidade. 
As tarifas residenciais de energia para cada tipo de consumidor são obtidas através da definição em um primeiro momento pelo ente regulador da tarifa de energia elétrica que será aplicada aos consumidores com fogões a gás e a aplicação de um coeficiente para se obter o preço "preferencial" aplicado às residências equipadas com fogões elétricos.

A eficiência desse modelo pode ser questionada pois o coeficiente de definição do preço preferencial foi determinado no passado, ainda no tempo da URSS. O seu cálculo considerou a quantidade de gás e eletricidade que cada grupo de consumidores utiliza em média ao longo de um mês, definindo quais os preços que equalizaram seus gastos e essa proporção tem sido utilizada desde então sem qualquer atualização (Vakhitova, 1998). Essa abordagem seria adequada se pudesse ser admitido que os preços iniciais eram "corretos" e que os níveis médios de consumo se mantivessem inalterados, o que é questionável pois nos tempos da URSS os preços da energia elétrica eram instrumentos de política econômica fixados ad hoc, não refletindo os seus custos de produção, além de, desde o fim da URSS, o consumo residencial de energia elétrica ter diminuído mais de $30 \%$ indicando mudança no perfil de consumo ou na tecnologia utilizada.

\subsection{A universalização do acesso}

A universalização dos serviços públicos apresenta duas dimensões: a primeira é assegurar a oferta desses serviços a toda a população (exclusão), e a segunda é assegurar que todos tenham condições de pagamento suficiente para níveis mínimos de suprimento de tais serviços, de modo a atender as necessidades básicas de toda a população (Tarifa Social). As políticas de universalização de acesso, com a expansão das redes físicas, pressupõem mecanismos que possibilitem aos consumidores mais pobres pagar pelo consumo de tais serviços, como a Tarifa Social.

A exclusão elétrica é um problema essencialmente regional (mais grave nas regiões $\mathrm{NE}, \mathrm{N}$ e $\mathrm{CO}$ ) e particularmente mais grave nas áreas rurais. Em nível nacional a ISEB atende a $96 \%$ dos domicílios com a rede de distribuição de energia elétrica, porém em algumas regiões, em especial a zona rural da Região do Nordeste esse índice é de apenas 58\%. Segundo estudo do TCU (Campelo et al., 2003) com dados da PNAD de 2001, o serviço de distribuição de energia elétrica é o que atende a uma 
maior parcela dos domicílios, ao ser comparado com outros tipos de serviços públicos relacionados à infra-estrutura, como fornecimento de água, telefonia e saneamento.

\begin{tabular}{|l|c|c|}
\hline Alcance dos Serviços Públicos & $\mathbf{1 9 9 3}$ & $\mathbf{2 0 0 1}$ \\
\hline Rede de energia elétrica & 91,0 & 96,2 \\
\hline Rede de abastecimento de água & 78,7 & 86,6 \\
\hline Coleta de lixo & 71,1 & 83,9 \\
\hline Rede de saneamento básico & 52,1 & 50,3 \\
\hline Rede de telefonia convencional & 20,0 & 50,3 \\
\hline Serviço de telefonia celular & - & 32,4 \\
\hline
\end{tabular}

Quadro 20 - Percentual de cobertura de serviços públicos em 1993 e 2001.

Fonte: elaborado por Campelo et al. (2003)

O diagnóstico da forte influência regional sobre o fenômeno da exclusão elétrica é claro a partir da análise dos microdados da PNAD: 63,9\% dos domicílios sem acesso à energia elétrica situam-se na região Nordeste, e 81,6\% dos domicílios sem acesso à energia elétrica estão situados na zona rural (Campelo et al., 2003).
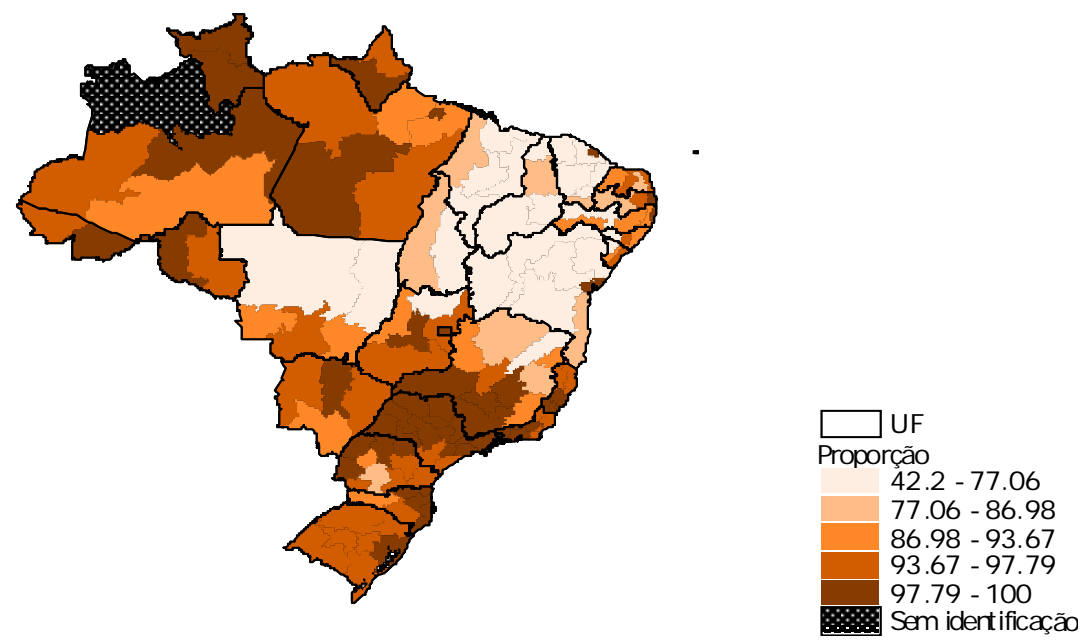

Figura 18 - População com acesso à energia elétrica 1996 a 1999.

Fonte: elaborado por Campelo et al. (2003) 
Esses mesmos dados demonstram que a exclusão elétrica é mais freqüente em domicílios com maior número de moradores e menor número de cômodos, ambos indicativos de baixa renda familiar.

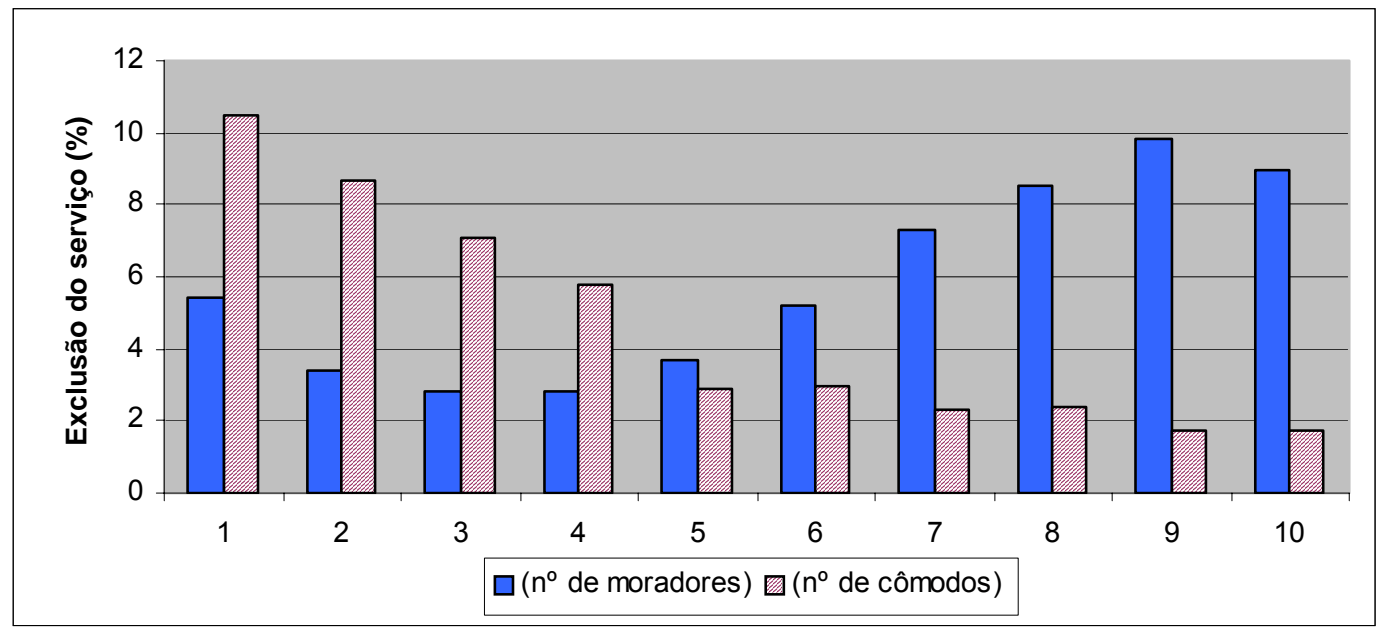

Figura 19 - Residências sem acesso à energia elétrica.

Fonte: elaborado por Campelo et al. (2003)

A maioria dos domicílios que não têm acesso à rede de distribuição de energia elétrica são aqueles que possuem 4 ou 5 cômodos, com até 5 moradores, e que não possuem acesso, também, às redes de água tratada, à rede sanitária e à coleta de lixo. Os mesmos dados (Campelo et al., 2003) demonstram que a exclusão elétrica é mais grave entre as famílias cujo chefe tem poucos anos de estudo e cujo ramo de ocupação é agrícola.

\begin{tabular}{|c|l|c|}
\hline \% de grupos característicos entre os excluídos elétricos \\
\hline Água canalizada & Tem & 15,0 \\
& Não tem & 85,0 \\
\hline \multirow{4}{*}{ Esgoto } & Rede de esgoto & 3,9 \\
& Fossa séptica ligada à rede & 0,7 \\
& Fossa séptica não ligada à rede & 5,8 \\
& Fossa rudimentar & 70,3 \\
& Vala e outros tipos & 19,1 \\
\hline \multirow{5}{*}{ Material das paredes externas } & Alvenaria & 63,1 \\
& Madeira aparelhada & 10,8 \\
& Taipa não revestida & 19,2 \\
& Madeira aproveitada & 3,1 \\
& Palha & 2,7 \\
\hline
\end{tabular}

Quadro 21 - Características dos domicílios sem acesso à energia elétrica.

Fonte: elaborado por Campelo et al. (2003) 
A exclusão elétrica também é diretamente relacionada com baixos níveis de renda, conforme Quadro 22.

\begin{tabular}{|c|c|c|c|}
\hline & $\begin{array}{c}\% \text { sem energia pc } \\
\text { faixa }\end{array}$ & $\begin{array}{r}\text { \% faixa de rend } \\
\text { da população }\end{array}$ & $\begin{array}{l}\text { \% sem energia sobre } \\
\text { total da população }\end{array}$ \\
\hline Renda zero & 6,0 & 1,8 & 0,1 \\
\hline 0 a $50 \mathrm{R} \$ / \mathrm{mês}$ & 14,7 & 8,7 & 1,3 \\
\hline 50 a 100 R $\$ /$ mês & 6,3 & 15,9 & 1,0 \\
\hline 100 a $150 \mathrm{R} \$ / \mathrm{mês}$ & 3,7 & 12,9 & 0,5 \\
\hline 150 a $200 \mathrm{R} \$ / \mathrm{mês}$ & 3,5 & 12,6 & 0,4 \\
\hline 200 a 300 R\$/mês & 1,6 & 14,0 & 0,2 \\
\hline 300 a $400 \mathrm{R} \$ / \mathrm{mês}$ & 1,1 & 8,4 & 0,1 \\
\hline 400 a 500 R\$/mês & 0,4 & 5,3 & 0,0 \\
\hline 500 a 750 R\$/mês & 0,4 & 7,2 & 0,0 \\
\hline 750 a $1000 \mathrm{R} \$ /$ mês & 0,2 & 3,5 & 0,0 \\
\hline mais de $1000 \mathrm{R} \$ /$ mês & 0,1 & 7,8 & 0,0 \\
\hline Total & 3,8 & 100,0 & 3,8 \\
\hline
\end{tabular}

Quadro 22 - Parcela de excluídos elétricos por faixa de renda, participação das faixas de renda sobre o total da população e percentual de excluídos por faixa de renda sobre o total da população.

Fonte: elaborado por Campelo et al. (2003)

O Programa "Luz no Campo" do Governo Federal, através do MME e com o apoio financeiro e técnico da Eletrobrás, pretendia entre 2000 e 2003 levar a rede de energia elétrica a 1 milhão de domicílios situados na zona rural em todo o país, através das concessionárias locais, sob coordenação da Eletrobrás. Os recursos estimados para investimento no "Luz no Campo" são de R\$ 1,77 bilhão, financiados pela Eletrobrás, com recursos da Reserva Global de Reversão, RGR.

O Programa "Energia das Pequenas Comunidades" tem como objetivo atender com energia elétrica as localidades isoladas não supridas pela rede convencional, através da instalação de 12.489 kits fotovoltaicos de eletrificação em escolas e postos de saúde. Esse programa visa à utilização de fontes de energia renováveis em localidades não atendidas pela rede elétrica convencional para aplicação comunitária com fontes de energia fotovoltaicas, eólicas, hidráulicas ou a biomassa. Em 2001, 
cerca de 3 mil escolas públicas foram atendidas com energia fotovoltaica com capacidade para iluminação, TV, vídeo, antena parabólica e bebedouro, podendo atender em média 44 alunos por escola. 


\section{CONCLUSÕES}

A cobrança de preços diferenciados para o mesmo bem (unidade de energia) é prática corrente pois as empresas de distribuição de energia elétrica são monopolistas em relação a todos os consumidores de energia elétrica em sua área geográfica de concessão. A impossibilidade de arbitragem e revenda do bem, que além de anti-econômica é ilegal, confere condições para a prática de discriminação de preços.

A fixação de diferentes preços sobre esse bem ocorre em função das diferentes demandas dos consumidores atendidos e permite a implementação de estratégias de maximização do lucro.

A Tarifa Social consiste em um mecanismo de discriminação de preços implementada em toda ISEB, que permite o atendimento de uma parcela do mercado consumidor (famílias de baixa renda) que poderia não ser incluída caso não fossem implementados os descontos.

A discriminação de preços permite às firmas integrantes da ISEB a expansão de seu mercado consumidor com a integração das famílias de baixa renda, sem que seja necessário reduzir-se os preços cobrados dos consumidores residenciais normais, reduzindo o consumo clandestino de energia e ampliando a sua receita.

No período 1985-2002 (vide 4.1) é possível identificar uma progressiva evolução do mecanismo de discriminação de preços, através de uma melhor identificação e classificação dos consumidores quanto à sua renda e propensão a pagar pelo serviço de energia elétrica.

No período 1985/1996 a Tarifa Social foi implementada através de um mecanismo de discriminação de preços de $2^{\circ}$ grau, através da concessão dos descontos em função dos níveis de consumo total, em que a progressividade da tarifa 
funcionava como mecanismo de auto-seleção dos consumidores com alta e baixa renda.

A partir de 1996 a Tarifa Social foi implementada conforme o modelo da discriminação de preços de $3^{\circ}$ grau, com a implementação de um mecanismo de barreira que separa de forma clara os consumidores de baixa e alta renda (vide 4.4), sendo cobradas tarifas diferentes em cada sub-mercado. Os critérios definidos em 2002 representam diretamente a renda da família, sendo mais eficientes para a prática de discriminação de preços, em oposição aos definidos em 1996 em que a renda era presumida em função de critérios "técnicos" relacionados aos consumo de energia.

A prática da discriminação de preços de $2^{\circ}$ e $3^{\circ}$ graus para a Tarifa Social no período considerado, além de serem consistentes com o objetivo de maximização do lucro das firmas, também apresenta resultados positivos em termos sociais, consistentes em um aumento da eficiência econômica com a minimização da perda de peso morto do monopólio. Além de tais vantagens a ampliação do acesso das famílias de baixa renda a esse serviço público representa um ganho social e permite a ocorrência das externalidades positivas relacionadas a esse consumo.

Os resultados da implementação da Tarifa Social no período compreendido nesse estudo, relação ao que foi ficado como meta na definição pioneira do $\mathrm{MME}$ (Bitu, 1985), não são conclusivos. A meta inicial do MME era de que o dispêndio mensal com o consumo de energia elétrica deveria corresponder a $4 \%$ do salário mínimo foi alcançada segundo os dados referidos no Quadro 25. Entretanto, a constatação de que os preços de energia elétrica aos consumidores residenciais brasileiros é a mais elevada em relação aos países em desenvolvimento e mais elevada em relação ao preço praticado em outros países de geração predominantemente hidráulica e de elevado padrão de renda (Canadá e Suécia, vide 4.4), apontam em sentido contrário.

A redução dos descontos e do universo de beneficiados com esses descontos a partir de 1996, quando ocorreu a privatização das distribuidoras da ISEB, permite inferir que a fixação desse esquema de preços (Tarifa Social) não é condicionada apenas aos alcances sociais definidos em sua criação, mas sofre influência das estratégias de maximização do lucro das firmas. 
A universalização do acesso à rede de fornecimento de energia elétrica apresenta-se como fator tão relevante quanto a adequada definição da política de discriminação de preços da Tarifa Social, pois as famílias sem acesso à rede de distribuição são as de menor renda e não são beneficiadas pela Tarifa Social, por mais amplos que sejam os descontos concedidos.

Para que seja ampliada a capacidade das famílias de baixa renda de pagamento pelo consumo de energia elétrica, ou seja que a Tarifa Social possua a eficácia necessária, é necessário uma redução nas tarifas médias de consumo do setor residencial, que são elevadas em funções dos parâmetros internacionais de tarifas em países em desenvolvimento, em especial das tarifas em países em que a energia têm origem em potenciais hidráulicos.

Sugere-se a redução dos custos mensais de consumo de energia elétrica através da redução da carga tributária incidente sobre o consumo, sem que sejam necessários mecanismos como os fixados com a Lei $n^{\circ} 10.438 / 2002$ de que as firmas distribuidoras sejam obrigadas a conceder descontos que serão subsidiados com recursos da RGR. 


\section{ANEXO}




\section{ANEXO - Subclasses tarifárias da ISEB - discriminação de preços.}

A estrutura tarifária definida na ISEB de segmentação de mercado (Álvares, 1978) considera três características básicas:

a) a definição da potência requerida, em kW, expressa pela taxa do fluxo de energia por unidade de tempo;

b) a energia total consumida em $\mathrm{kWh}$; e

c) a desagregação das diferentes características consideradas na definição da tarifa, a saber: categorias de consumidores, horários de utilização etc.

Estes requisitos técnicos permitem a previsão da demanda de energia, identificando os custos de fornecimento a cada consumidor segundo suas características e o reflexo das mesmas sobre o sistema. A partir dos dados sobre a potência requerida, a energia consumida e as características que compõem a demanda, é possível modelar as curvas de carga típicas dos consumidores e do sistema, além de caracterizar os usos e hábitos de consumo e prever a evolução do comportamento da demanda de acordo com as categorias de consumidores.

Essas diferentes características dos consumidores quanto à demanda de energia permite a definição de tarifas correspondentes, para a extração da remuneração adequada aos custos do sistema que podem ser classificadas (Pires \& Piccinini, 1998) como:

a) Tarifação Monômia: tarifas definidas apenas com base na energia consumida, ou seja, uma tarifa de consumo. O consumo consiste no registro de quanta energia elétrica foi consumida durante determinado período. No cálculo das faturas é considerado o período mensal e este é expresso em kWh;

b) Tarifação Binômia: tarifas que incorporam dois componentes de faturamento, a saber: um referente ao consumo de energia (tarifa de consumo) e outro equivalente à demanda máxima de potência requerida no período de utilização de ponta do sistema (tarifa de demanda; 
c) Tarifação Horosazonal: tarifas diferenciadas para grandes consumidores, de acordo com as horas do dia e/ou estações do ano de consumo e seu reflexo sobre a formação da demanda e consumo "de ponta";

d) Tarifação em Blocos: o preço unitário varia de acordo com o total de kWh consumido;

e) Tarifação de Energia Interruptível: modalidade tarifária em que o consumidor concorda em ser desconectado sempre que existir dificuldade de fornecimento de energia por parte da concessionária;

f) Tarifação de Energia Instantânea: tarifas cujos valores apresentam grandes variações em curtos períodos de tempo.

Para o cálculo do preço da energia elétrica, além dessas tarifas podem ser consideradas as seguintes:

\begin{tabular}{|c|c|}
\hline Tarifa Azul & Tarifa Verde \\
\hline Demanda na Ponta & Demanda \\
\hline Demanda Fora de Ponta & Consumo na Ponta \\
\hline Consumo na Ponta & Consumo Fora de Ponta \\
\hline Consumo Fora de Ponta & \\
\hline
\end{tabular}

Quadro 23 - Tarifas diferenciadas em função do hábito de consumo (horários).

Fonte: elaborado com base (ANEEL, 2000)

Considerando-se que a capacidade de geração de energia na ISEB é essencialmente hidráulica, o "período chuvoso" apresenta o maior potencial de geração de energia elétrica. Essa característica motivou a implementação a partir de 1982 da nova Estrutura Tarifaria Horo-sazonal, em que as tarifas tem valores diferenciados segundo os horários do dia e períodos do ano, devido às características pluviométricas da região.

Além da diferenciação tarifária quanto ao perfil de consumo em relação aos períodos de consumo e ao regime pluviométrico, que influi sobre a capacidade de geração de energia, a tarifação na ISEB também discrimina os consumidores quanto ao total de energia consumida, sendo impostas tarifas menores aos consumidores de maior consumo mensal. Em função do total mensal consumido de energia os 
consumidores, a diferenciação tarifária abrange as seguintes classes de consumidores em função da tensão de fornecimento de energia:

\begin{tabular}{|l|l|}
\hline \multicolumn{1}{|c|}{ Grupo A - Alta Tensão } & \multicolumn{1}{c|}{ Grupo B - Baixa Tensão } \\
\hline A-1 - 230 kV ou mais; & B-1 - Residencial; \\
\hline A-2 - 88 a 138 kV; & B-1 - Residencial Baixa Renda; \\
\hline A-3 - 69 kV; & B-2 - Rural; \\
\hline A-3a - 30 a 44 kV; e & B-3 - Não Residencial Nem Rural; e \\
\hline A4 - 2,3 kV a 25 kV & B-4 - Iluminação Pública. \\
\hline A.S. - 2,3 a 13,8 Kv (Subterrâneo). & \\
\hline
\end{tabular}

Quadro 24 - Tarifas diferenciadas em função da quantidade e destinação do consumo. Fonte: elaborado com base (ANEEL, 2000)

A discriminação de preços na ISEB, definida pela legislação, não envolve apenas a diferenciação dos consumidores quanto ao total de energia consumida e o período ou horário em que a mesma é demanda do SIN. Essa diferenciação tarifária também tem como base o tipo de atividade exercida pelo consumidor, com reflexo direto sobre a receita da distribuidora que atende o mercado local. A diferenciação tarifária é aplicada às diferentes classes e subclasses de consumidores, que são definidas, atualmente, pela Resolução n 456 da ANEEL, de 29 de novembro de 2000 e descritas a seguir.

\begin{tabular}{|c|l|}
\hline Classes Tarifárias & \multicolumn{1}{|c|}{ Subclasses } \\
\hline \multirow{2}{*}{ Serviço Público } & a) Tração Elétrica \\
\cline { 2 - 2 } & b) Água, Esgoto e Saneamento \\
\hline \multirow{2}{*}{ Iluminação pública } & \\
\hline Industrial & 29 subclasses \\
\hline \multirow{2}{*}{ Comercial } & \\
\hline & a) Comercial \\
\hline & b) Serviços de Transporte, exclusive tração elétrica \\
\hline & c) Serviços de Comunicações e Telecomunicações \\
\hline & d) Outros Serviços e outras atividades \\
\hline & \\
\hline
\end{tabular}




\begin{tabular}{|c|l|}
\hline \multirow{4}{*}{ Rural } & a) Agropecuária \\
\cline { 2 - 2 } & b) Cooperativa de Eletrificação Rural \\
\cline { 2 - 2 } & c) Indústria Rural \\
\hline & d) Coletividade Rural \\
\hline & e) Serviço Público de Irrigação Rural \\
\hline & f) Escola Agrotécnica \\
\hline \multirow{4}{*}{ Poder Público } & a) Poder Público Federal \\
\hline & b) Poder Público Estadual ou Distrital \\
\hline & c) Poder Público Municipal \\
\hline \multirow{2}{*}{ Consumo Próprio } & a) Próprio \\
\hline & b) Canteiro de Obras \\
\hline & c) Interno \\
\hline & a) Residencial \\
\hline \multirow{2}{*}{ Residencial } & b) Residencial Baixa Renda \\
\hline &
\end{tabular}

Quadro 25 - Principais classes e subclasses tarifárias da ISEB.

Fonte: elaborado com base (ANEEL, 2000)

A categoria de tarifação denominada "Serviço Público" engloba o fornecimento de energia elétrica para motores, máquina e cargas para a operação da rede pública de abastecimento de água, esgotamento sanitário e saneamento básico. A energia de tração utilizada pelo Poder Público para movimentar trens, tróleibus e metrôs também são incluídas nessa categoria tarifária. Esta classificação utilizada pelas concessionárias de distribuição de energia elétrica é subdivida em duas subcategorias; uma de tração elétrica e outra para fins de garantir o abastecimento de água, o saneamento básico e a rede de escoamento de esgoto. Essa classe de consumo possui duas subclasses: a) Tração Elétrica; e b) Água, Esgoto e Saneamento.

Cabe às prefeituras a iniciativa de implantar, operar e efetuar a manutenção das instalações de iluminação das vias pública, sendo esses serviços remunerados pelas tarifas de "Iluminação Pública". As concessionárias poderão prestar esses serviços, desde que sejam contratadas pela administração municipal, englobando todos os aspectos da prestação do serviço.

A classe de tarifação "Industrial" consiste na classe de fornecimento para unidade consumidora em que seja desenvolvida atividade industrial, inclusive o transporte de matéria-prima, insumo ou produto resultante do seu processamento, 
caracterizado como atividade de suporte e sem fim econômico próprio, desde que realizado de forma integrada fisicamente à unidade consumidora industrial. Essa classe de consumo é dividida em 29 subclasses de faturamento conforme as atividades classificadas no Cadastro Nacional de Atividades Econômicas.

Essa classe de consumidores foi o primeiro segmento beneficiado com as mudanças no conceito de consumidor estabelecidos pela ANEEL. O alto consumo individual das firmas que exercem atividades industriais permitiu que boa parte das empresas pudesse ser enquadrada na categoria dos "consumidores livres", com direito a escolher seu fornecedor de energia em função de tarifas competitivas que são oferecidas devido à inexistência de monopólio das concessionárias de distribuição sobre esse mercado.

A classe "Comercial" engloba as unidades consumidoras que exercem atividade comercial ou de prestação de serviços ou outra atividade não prevista nas demais classes, inclusive o fornecimento destinado às instalações de uso comum de prédio ou conjunto de edificações com predominância de unidades consumidoras não residenciais. Essa classe possui quatro subclasses de faturamento:

a) Comercial;

b) Serviços de Transporte, exclusive tração elétrica;

c) Serviços de Comunicações e Telecomunicações; e

d) Outros Serviços e outras atividades.

Essa classe de consumo tem apresentado crescente importância no faturamento das distribuidoras de energia elétrica. Em doze meses, de outubro de 1999 até outubro de 2000 , o aumento da demanda no segmento comercial foi de $9,4 \%$. No mesmo período, a média nacional ficou em $4,6 \%$.

A classe de faturamento "Rural" engloba unidades consumidoras que prestam atividades diversas e que tem como característica comum a localização física na zona rural. Essa classe apresenta seis diferentes subclasses de faturamento:

a) Agropecuária: que consiste no fornecimento para unidade consumidora cujo consumidor desenvolva atividade relativa à agricultura e/ou a criação, recriação ou engorda de animais, inclusive o beneficiamento ou a conservação de produtos agrícolas oriundos da mesma propriedade rural, 
bem como a transformação de produtos destinados à utilização exclusivamente na unidade consumidora,

b) Cooperativa de Eletrificação Rural;

c) Indústria Rural: onde seja desenvolvido processo industrial de transformação e/ou beneficiamento de produtos oriundos da atividade relativa à agricultura e/ou a criação, recriação ou engorda de animais, com potência instalada em transformadores não superior a 112,5 kVA.

d) Coletividade Rural: caracterizada por grupamento de usuários de energia elétrica, com predominância de carga em atividade classificável como agropecuária, que não seja cooperativa de eletrificação rural.

e) Serviço Público de Irrigação Rural: fornecimento exclusivo para bombeamento d'água para fins de irrigação, destinada à atividade agropecuária e explorada por entidade pertencente ou vinculada à Administração Direta, Indireta ou Fundações de Direito Público da União, dos Estados ou dos Municípios;

f) Escola Agrotécnica: onde seja desenvolvida atividade de ensino e pesquisa direcionada à agropecuária, sem fins lucrativos e explorada por entidade pertencente ou vinculada à Administração Direta, Indireta ou Fundações de Direito Público da União, dos Estados ou dos Municípios.

As cooperativas de eletrificação rural passaram a ser tratadas como permissionárias do serviço público pela ANEEL em 2000, depois de décadas de operação na informalidade. Essas cooperativas, mesmo sem qualquer suporte ou regulamentação estatal eram responsáveis por pequenas geradoras que supriam mais de cem mil propriedades e meio milhão de pessoas em 1.200 cidades. Com esse ato foram reconhecidas e oficializadas 124 cooperativas rurais, que possuem uma presença marcante nas regiões Nordeste (40,3\% do atendimento total) e Sul $(35,4 \%)$, e abastecem também as regiões Sudeste $(18 \%)$, Centro- Oeste $(4,8 \%)$ e Norte $(1,6 \%)$.

A categoria tarifária "Poder Público" é aplicada ao fornecimento de energia à estrutura administrativa do Estado, com exceção dos casos classificáveis como Serviço Público de Irrigação Rural, Escola Agrotécnica, lluminação Pública e Serviço Público. Essa classe de consumidores possui as seguintes subclasses: 
a) Poder Público Federal;

b) Poder Público Estadual ou Distrital; e

c) Poder Público Municipal.

A classe de "Consumo Próprio" envolve o faturamento da energia elétrica consumida pela própria concessionária de distribuição para o exercício de suas atividades. Nesse caso não há pagamento e o consumo é medido e registrado junto ao ente regulador, inclusive para efeitos de incidência de encargos legais. Essa modalidade de consumo engloba as seguintes subclasses:

a) Próprio: consumo registrado nos escritórios, oficinas, almoxarifado e demais instalações da própria concessionária, diretamente ligadas à administração da prestação dos serviços de fornecimento de eletricidade;

b) Canteiro de Obras: fornecimento para canteiro de obras da própria concessionária;

c) Interno: fornecimento para instalações e dependências internas de usinas, subestações e demais locais diretamente ligados à produção e transformação de energia elétrica.

A classe tarifária "Residencial" remunera o fornecimento de energia elétrica para unidade consumidora com fim residencial inclui a diferenciação tarifária para as seguintes subclasses:

a) Residencial: fornecimento para unidade consumidora com fim residencial, incluído o fornecimento para instalações de uso comum de prédio ou conjunto de edificações, com predominância de unidades consumidoras residenciais; e

b) Residencial Baixa Renda: fornecimento para unidade consumidora residencial, caracterizada como de "baixa renda" de acordo com os critérios estabelecidos em regulamentos específicos. 


\section{REFERÊNCIAS BIBLIOGRÁFICAS}

ABREU, Y.V. A reestruturação do setor elétrico brasileiro: questões e perspectivas. São Paulo, 1999. 184p. Dissertação (Mestrado) - Programa de Interunidades de Pós-Graduação em Energia, Universidade de São Paulo.

AGÊNCIA NACIONAL DE ENERGIA ELÉTRICA. Consumidor residencial de baixa renda diagnóstico: relatório preliminar versão 1. Brasília: Superintendência de Regulação da Comercialização da Eletricidade (SRC), 1999. 39p.

AGÊNCIA NACIONAL DE ENERGIA ELÉTRICA. Atlas de energia elétrica do Brasil. Brasília: ANEEL, 2002. 153p.

ÁLVARES, V.T. Curso de direito de energia. Rio de Janeiro: Forense, 1978. 692p.

ANDRADE, T.A.; LOBÃO, W.J.A. Elasticidade renda e preço da demanda residencial de energia elétrica no Brasil. Rio de Janeiro: IPEA, 1997. 25p. (Texto para Discussão, 489)

ARAUJO, J.L.R.H. Regulação de monopólios e mercados: questões básicas. /Apresentado no 1. Seminário Nacional do Núcleo de Economia da Infraestrutura, Rio de Janeiro, 2000/ http://www.provedor.nuca.ie.ufrj.br/eletrobras/ biblioteca/a.htm (05 abr. 2003) 
BARROS, C.V.M. Reestruturação do setor elétrico e concorrência. São Paulo, 2000. 222p. Tese (Doutorado) - Faculdade de Direito, Universidade de São Paulo.

BARBOSA, F.H. A eficiência da intervenção do Estado na economia. São Paulo: FGV, 1991. 38p. (Ensaios Econômicos da EPGE, 183)

BITU, R.S. (Org.). Tarifa Social. Brasília: DNAEE, 1986. 248p.

BORESTEIN, C.R.; CAMARGO, C.C.B. O setor elétrico no Brasil: dos desafios do passado às alternativas do futuro. Porto Alegre: Sagra Luzzatto, 1997. 318p.

BRASIL. Agência Nacional de Energia Elétrica. Resolução n 456 de 29 de novembro de 2000. Diário Oficial, v.138, n.230-E, 30 nov. 2000. Seção 1, p.35. Estabelece, de forma atualizada e consolidada, as condições gerais de fornecimento de energia elétrica.

BRASIL. Agência Nacional de Energia Elétrica. Resolução nº 246 de 30 de abril de 2002. Diário Oficial da União, v.139, n.83, 02 maio 2002. Seção 1, p.71. Estabelece as condições para enquadramento na subclasse residencial baixa renda de unidade consumidora com consumo mensal inferior a $80 \mathrm{kWh}$.

BRASIL. Agência Nacional de Energia Elétrica. Resolução $n^{\circ} 485$ de 29 de agosto de 2002. Diário Oficial da União, v.139, n.168, 30 ago. 2002. Seção 1, p.106. Estabelece as diretrizes para a classificação na subclasse residencial baixa renda de unidade consumidora com consumo mensal entre 80 e 220 kWh, regulamentando o Decreto 4.336 de 16.08.2002, e dá outras providências.

BRASIL. Comitê de revitalização do setor elétrico. Documento de apoio A: resumo do marco regulatório brasileiro. Brasília: ANEEL/GCE, 2002. p.102-118. (Relatório de progresso, 2) http://www.energiabrasil.gov.br/indice (05 maio 2002) 
BRASIL. Departamento Nacional de Energia Elétrica. Portaria $n^{\circ} 337$ de 22 de abril de 1994. Diário Oficial da União, 25 abr. 1994. Seção 1, p.6007. Regulamenta o Sistema Nacional de Transmissão de Energia Elétrica - SINTREL.

BRASIL. Departamento Nacional de Águas e Energia Elétrica. Portaria $n^{\circ} 437$ de 03 de novembro de 1995. Diário Oficial da União, 06 nov. 1995. Seção 1, p.17708. Altera a redação da Portaria DNAEE 222 de 22.12.1987, que estabelece as disposições relativas às condições gerais de fornecimento a serem observadas na prestação e utilização do Serviço Público de Energia Elétrica.

BRASIL. Ministério de Minas e Energia. Proposta de modelo institucional do setor elétrico. Brasília, 2003. /Nota Técnica/

BRASIL. Leis, Decretos, etc. Lei n 5655 de 20 de maio de 1971. Diário Oficial da União, 21 maio 1971. Col.1, p.3841. Dispõe sobre a remuneração legal do investimento dos concessionários de serviços públicos de energia elétrica, e dá outras providências.

BRASIL. Leis, Decretos, etc. Decreto $\mathrm{n}^{\circ} 79.706$ de 18 de maio de 1977 . Diário Oficial da União, 19 maio 1977. Col.1, p.6013. Dispõe sobre os atos da administração pública relativamente ao controle de preços.

BRASIL. Leis, Decretos, etc. Lei $n^{\circ} 8631$ de 04 de março de 1993. Diário Oficial da União, 05 mar. 1993. Col.1, p.2597. Dispõe sobre a fixação dos níveis das tarifas para o serviço público de energia elétrica, extingue o regime de remuneração garantida e dá outras providências. 
BRASIL. Leis, Decretos, etc. Decreto $n^{\circ} 774$ de 18 de março de 1993. Diário Oficial da União, 19 mar. 1993. Col.1, p.3289. Regulamenta a Lei $n^{\circ} 8.631$, de 4 de março de 1993, que dispõe sobre a fixação dos níveis das tarifas para o serviço público de energia elétrica, extingue o regime de remuneração garantida e dá outras providências.

BRASIL. Leis, Decretos, etc. Decreto n 915 de 06 de setembro de 1993. Diário Oficial da União, 08 set. 1993. Col.2, p.13334. Autoriza a formação de consórcios para geração de energia elétrica.

BRASIL. Leis, Decretos, etc. Decreto $n^{\circ} 1009$ de 22 dezembro de 1993. Diário Oficial da União, 23 dez. 1993. Col.2, p.20220. Cria o Sistema Nacional de Transmissão de Energia Elétrica SINTREL, e dá outras providências.

BRASIL. Leis, Decretos, etc. Lei n 8987 de 13 de fevereiro de 1995. Diário Oficial da União, 14 fev. 1995. Col.1, p.1917. Dispõe sobre o regime de concessão e permissão da prestação de serviços públicos previsto no art. 175 da Constituição Federal, e dá outras providências.

BRASIL. Leis, Decretos, etc. Lei no 9074 de 07 de julho de 1995. Diário Oficial da União, 08 jul. 1995. Col.1, p.10125. Dispõe sobre o regime de concessão e permissão da prestação de serviços públicos previsto no art. 175 da Constituição Federal, e dá outras providências.

BRASIL. Leis, Decretos, etc. Lei n 9427 de 26 de dezembro de 1996. Diário Oficial da União, 27 dez. 1996. Col.1, p. 28653. Institui a Agência Nacional de Energia Elétrica - ANEEL, disciplina o regime das concessões de serviços públicos de energia elétrica e dá outras providências. 
BRASIL. Leis, Decretos, etc. Lei no 9433 de 08 de janeiro de 1997. Diário Oficial da União, 09 jan. 1997. Col.1, p.470. Institui a Política Nacional de Recursos Hídricos, cria o Sistema Nacional de Gerenciamento de Recursos Hídricos, regulamenta o inciso XIX do art. 21 da Constituição Federal, e altera o art. $1^{\circ}$ da Lei $n^{\circ}$ 8.001, de 13 de março de 1990, que modificou a Lei $n^{0} 7.990$, de 28 de dezembro de 1989.

BRASIL. Leis, Decretos, etc. Decreto $n^{\circ} 3877$ de 24 de julho de 2001. Diário Oficial da União, 25 ago. 2001. Col.1, p.68. Institui o cadastramento único para programas sociais do Governo Federal.

BRASIL. Leis, Decretos, etc. Medida Provisória n 2198-5 de 24 de agosto de 2001. Diário Oficial da União, 27 ago. 2001. Col.2, p.61. Cria e instala a Câmara de Gestão da Crise de Energia Elétrica, do Conselho de Governo, estabelece diretrizes para programas de enfrentamento da crise de energia elétrica e dá outras providências.

BRASIL. Leis, Decretos, etc. Decreto $n^{\circ} 4102$ de 24 de janeiro de 2002. Diário Oficial da União, 25 jan. 2002. Col.3, p.2. Regulamenta a Medida Provisória $\mathrm{n}$ ㅇ 18, de 28 de dezembro de 2001, relativamente ao "Auxílio-Gás".

BRASIL. Leis, Decretos, etc. Lei $n^{\circ} 10438$ de 26 de abril de 2002. Diário Oficial da União, 29 abr. 2002. Col.1, p.1. Dispõe sobre a expansão da oferta de energia elétrica emergencial, recomposição tarifária extraordinária, cria o Programa de Incentivo às Fontes Alternativas de Energia Elétrica (Proinfa), a Conta de Desenvolvimento Energético ( $C D E$ ), dispõe sobre a universalização do serviço público de energia elétrica, dá nova redação às Leis $\mathrm{n} \cong 9.427$, de 26 de dezembro de 1996, nำ.648, de 27 de maio de 1998, $\mathrm{n}$ ㅇ.890-A, de 25 de abril de 1961, n 5.655, de 20 de maio de 1971, n ํ⒌899, de 5 de julho de 1973, nํ⒐991, de 24 de julho de 2000, e dá outras providências. 
BRASIL. Leis, Decretos, etc. Decreto $n^{\circ} 4336$ de 15 de agosto de 2002. Diário Oficial da União, 16 ago. 2002. Col.2, p.2. Dispõe sobre a utilização de recursos da Reserva Global de Reversão - RGR para o financiamento do atendimento a consumidores de baixa renda, e dá outras providências..

BRASIL. Ministério de Minas e Energia. Portaria n 817 de 28 de junho de 1985. Diário Oficial da União, 02 jul. 1985. Seção 1, p.9388. Determina que o Departamento Nacional de Águas e Energia Elétrica - DNAEE constitua comissão, sob sua coordenação, integrando-a dirigentes do Setor Elétrico de cada região do País, para apresentar, num prazo de 90 dias, proposta de tarifas residenciais de cunho social e suas condições de aplicação, incluindo o perfil dos consumidores de baixa renda, a serem atingidos por essas tarifas.

BRASIL. Presidência da República. Câmara de Gestão da Crise de Energia Elétrica. Resolução $n^{\circ} 18$ de 22 de junho de 2001. Diário Oficial da União, 23 jun. 2001. Edição extra. Cria o Comitê de Revitalização do Modelo do Setor Elétrico.

CAMARA DOS DEPUTADOS. Avaliação do preço da energia elétrica para o consumidor direto brasileiro. Brasília, 2003. /Nota Técnica/

CAMPELO, V.; VILAÇA, M.V.; SOUTO, H.G. Verificação se os critérios de implementação da Tarifa Social beneficiam efetivamente as famílias de baixa renda. Brasília: Tribunal de Contas, 2003. 34p. (Relatório de Auditoria TC 014.698/2002-7)

COMPANHIA ENERGÉTICA DE SÃO PAULO. Consumo médio, habitantes por consumidor residencial e consumo de iluminação pública por consumidor residencial dos municípios da área de concessão da CESP. São Paulo: CESP, 1981. $48 p$. 
DIAS, R.F. (Coord.). Memória da eletricidade: notas sobre o racionamento de energia elétrica no Brasil (1940-1980). Rio de Janeiro: Centro da Memória da Eletricidade no Brasil, 1996. 264p.

EATON, B.C.; EATON, D.F. Microeconomia. Trad. de C. C. Bartalotti. São Paulo: Saraiva, 1999. 606p.

FIANI, R. Teoria da Regulação Econômica: estado atual e perspectivas futuras. Rio de Janeiro: Universidade Federal do Rio de Janeiro, Instituto de Economia, 1998. 40p. (Texto para discussão, 483)

FRANÇA, C.R.A. Programas sociais em empresa estatal de serviço público: análise dos projetos de eletrificação de áreas residenciais urbanas de baixa renda na Eletropaulo S/A e de suas perspectivas sob gestão privada. São Paulo, 1999. 166p. Dissertação (Mestrado) - Instituto de Eletrotécnica e Energia, Universidade de São Paulo.

FRANK, R.H. Microeconomia e comportamento. 3.ed. Lisboa: McGraw-Hill de Portugal, 1997. 745p.

LOOTY, M.; SZAPIRO, M. Economias de escala e escopo. In: KUPFER, D.; HASENCLEVER, L. (Org.). Economia industrial: fundamentos teóricos e práticas no Brasil. Rio de Janeiro: Campus, 2002. cap.3, p.43-70.

MELO, L.M. Modelos tradicionais de concorrência. In: KUPFER, D.; HASENCLEVER, L. (Org.). Economia industrial: fundamentos teóricos e práticas no Brasil. Rio de Janeiro: Campus, 2002. cap.1, p.3-22. 
PINEAU, P.O. Competition, marginal costing price and profitability in the electricity sector. http://web.uvic.ca/padm/faculty/pineau/pdfs/Profitability MCPricing.pdf (23 Feb. 2003)

PINTO JUNIOR, H.Q.; SILVEIRA, J.P. Elementos da regulação setorial e de defesa da concorrência: uma agenda de questões para o setor de energia. Brasília: Agência Nacional do Petróleo, 1997. 22p.

PIRES, J.C.L.; PICCININI, M.S. A regulação de setores de infra-estrutura no Brasil. In: GIAMBIAGI, F.; MOREIRA, M.M. (Org.). A economia brasileira nos anos 90. Rio de Janeiro: BNDES, 1999. p.89-103.

PIRES, J.C.L.; PICCININI, M.S. Modelos de regulação tarifária do setor elétrico. Revista BNDES, n.9, p.43-62, jun.1998.

PRADO JUNIOR, F.A.A. A tarifa residencial de baixa renda uma análise de sua aplicação perante a questão de subsídios cruzados. In: CONGRESSO BRASILEIRO DE PLANEJAMENTO ENERGÉTICO, 3., São Paulo, 1998. http://www.eletrobras.gov.br/downloads/EM_Biblioteca/mestrado_marseille.pdf (24 abr. 2003).

RAMALHO, E.L. A redistribuição de renda através de tarifas sociais no setor elétrico: atuação do órgão regulador. In: CIDEL ARGENTINA 2002: CONGRESSO INTERNACIONAL DE DISTRIBUCION ELECTRICA. http://www.cier.org.uy/aan /dc/2002/cidel/4.6.28.pdf (13/06/2003)

ROSA, L.P. A crise de energia elétrica: causas e medidas de mitigação. In: BRANCO, A. M. (Org.). Política energética e crise de desenvolvimento: a antevisão de Catullo Branco. São Paulo: Paz e Terra, 2002. cap.3, p.81-96. 
SALGADO, L.H. Agências regulatórias na experiência brasileira: um panorama do atual desenho institucional. Rio de Janeiro: IPEA, 2003. (Texto para Discussão, 941)

SAMBO, M. Entenda a tarifa de energia: maior parte da tarifa não fica na distribuidora. Expresso: Jornal da CPFL Energia, Campinas, 10 mar. 2003. p.2.

SANTANA, E.A.; OLIVEIRA, C.A.C.N.V. Regulação e coordenação: duas fontes de ineficiência da indústria de energia elétrica. In: BORENSTEIN, C.R.; CAMARGO, C.C.B.; CUNHA, C.J.C.A. (Coord.) et al. Regulação e gestão competitiva no setor elétrico brasileiro. Porto Alegre: Sagra Luzzatto, 1999. 280p.

SAUER, I.L.; PEDREIRA, M.O.; ALMEIDA, M.O. et al. Análise de cadastros de concessionárias: relatório de aplicações. São Paulo, 2000. http://www.iee.usp.br/biblioteca/producao/2000//ldo\%20Relatorio\%20de\%20aplicaç ões\%20-\%20CADASTRO.pdf (05 mar. 2003)

SAUER, I. Energia elétrica no Brasil contemporâneo: a reestruturação do setor, questões e alternativas. In: BRANCO, A.M. (Org.). Política energética e crise de desenvolvimento: a antevisão de Catullo Branco. São Paulo: Paz e Terra, 2002. cap.5, p.117-227.

SENADO FEDERAL. Evolução dos gastos sociais federais no período 1992/2000. Brasília, 2001. 13p. /Nota Técnica/

VARIAN, H.R. Microeconomia: princípios básicos. Rio de Janeiro: Campus, 1999. 740 . 
VAKHITOVA, $\mathrm{H}$. Price discrimination in the urban household electricity market in Ukraine. Kiev, 1998. 41p. Thesis (Master) - National University "KievMohyla Academy". 